\title{
Connecting the Missing Dots: ncRNAs as Critical Regulators of Therapeutic Susceptibility in Breast Cancer
}

\author{
Elena-Georgiana Dobre ${ }^{1,2} \mathbb{D}$, Sorina Dinescu ${ }^{2,3, *(\mathbb{D})}$ and Marieta Costache 2,3 (D) \\ 1 AMS Genetic Lab, 030882 Bucharest, Romania; dobregeorgiana_95@yahoo.com \\ 2 Department of Biochemistry and Molecular Biology, University of Bucharest, 050095 Bucharest, Romania; \\ marieta.costache@bio.unibuc.ro \\ 3 The Research Institute of the University of Bucharest, 050095 Bucharest, Romania \\ * Correspondence: sorina.dinescu@bio.unibuc.ro
}

Received: 8 August 2020; Accepted: 14 September 2020; Published: 21 September 2020

Simple Summary: Despite considerable improvements in diagnosis and treatment, drug resistance remains the main cause of death in BC. Multiple lines of evidence demonstrated that ncRNAs play a vital role in $\mathrm{BC}$ resistance. Here, we summarized the molecular mechanisms by which miRNAs and lncRNAs may impact the therapeutic response in BC, highlighting that these molecules can be further exploited as predictive biomarkers and therapeutic targets. By merging data from various studies, we concluded that several ncRNAs, such as miR-221, miR-222, miR-451, UCA1, and GAS5 are strong candidates for pharmacological interventions since they are involved in resistance to all forms of therapies in BC. Therefore, we believe that our review provides an important reservoir of molecules that may translate into clinically useful biomarkers, laying the ground for the adoption of ncRNAs within mainstream routine oncology clinical practice.

\begin{abstract}
Whether acquired or de novo, drug resistance remains a significant hurdle in achieving therapeutic success in breast cancer (BC). Thus, there is an urge to find reliable biomarkers that will help in predicting the therapeutic response. Stable and easily accessible molecules such as microRNAs (miRNAs) and long non-coding RNAs (lncRNAs) are regarded as valuable prognostic biomarkers and therapeutic targets since they act as crucial regulators of the various mechanisms involved in BC drug resistance. Here, we reviewed the current literature on ncRNAs as mediators of resistance to systemic therapies in BC. Interestingly, upon integrating data results from individual studies, we concluded that miR-221, miR-222, miR-451, Urothelial Carcinoma Associated 1 (UCA1), and Growth arrest-specific 5 (GAS5) are strong candidates as prognostic biomarkers and therapeutic targets since they are regulating multiple drug resistance phenotypes in BC. However, further research around their clinical implications is needed to validate and integrate them into therapeutic applications. Therefore, we believe that our review may provide relevant evidence for the selection of novel therapeutic targets and prognostic biomarkers for BC and will serve as a foundation for future translational research in the field.
\end{abstract}

Keywords: breast cancer; drug resistance; miRNAs; lncRNAs; biomarkers; therapeutic targets

\section{Introduction}

Breast cancer $(\mathrm{BC})$ is the most frequent malignancy diagnosed in women and the second leading cause of cancer-related deaths in females worldwide [1]. According to the most recent GLOBOCAN estimates, nearly 2.1 million women were diagnosed with BC worldwide in 2018, which resulted in 
626,679 deaths [2]. Notably, late diagnosis [3] and the occurrence of drug resistance [4] are the main factors that account for the increased rate of fatality.

$\mathrm{BC}$ is a highly heterogeneous disease, clinically divided into three broad subgroups: hormone receptor-positive (that express receptors for estrogen and progesterone), human epidermal growth factor receptor 2 (HER2)-positive, and triple-negative breast cancer (TNBC), that lacks all of these receptors. Additional subtypes are now recognized, including luminal A, luminal B, HER2-enriched, claudin-low, basal-like, and normal breast-like, where the last three are part of TNBC. These subdivisions are different in terms of epidemiology, prognosis, and sensitivity to treatment and are very useful in guiding the therapeutic decisions $[5,6]$. In the last years, the combined use of endocrine, targeted, and cytotoxic agents has considerably improved the quality of life and survival in BC patients. However, a significant proportion of patients fails to respond to therapy due to the acquired or de novo drug resistance, which results in metastatic disease [7]. The recurrent disease usually spread to distant sites, such as the brain, bone, lung, and liver [8], and correlates with a dismal 5-year survival rate of $27 \%$ [9]. Enhanced drug efflux, alteration of drug targets (e.g., estrogen receptor (ER), human epidermal growth factor receptor 2 (HER2)), increased DNA damage repair (DDR), activated cancer stem cells (CSCs) and epithelial-mesenchymal transition (EMT), defective cell cycle control, apoptosis/survival pathways dysregulation, and the oncogenic signals within the tumor microenvironment (TME) have been extensively reviewed in association with the development of drug resistance in BC [10-12]. However, little is known about the processes driving the perturbation of these signaling pathways and the precise drug resistance-associated networks in BC [13].

Non-coding RNAs (ncRNAs) are biologically active transcripts originating from the mammalian genome without protein-coding potential. These entities make up almost $97-98 \%$ of the human genome and are involved in various biological processes in health and disease, including the pathophysiology of BC. ncRNAs can be broadly divided into small non-coding RNAs (sncRNAs, $<200$ nucleotides) and long non-coding RNAs (lncRNAs, $>200$ nucleotides), based on their size [14]. There are different species of sncRNAs, including the notorious microRNAs (miRNAs), piwi-interacting RNAs (piRNAs), short interfering RNAs (siRNAs), small nuclear RNAs (snRNAs), and small nucleolar RNAs (snoRNAs) [15,16]. A novel addition to those sub-classes of ncRNAs are circular RNAs transcripts (circRNAs), generated through back-splicing of pre-mRNAs [17]. These molecules possess a unique circular conformation that endows them with enhanced stability compared to their linear RNA cognates. circRNAs are currently attracting considerable research attention as they are regulating multiple molecular mechanisms in health and disease, by which miRNA sponging is the most prominent [17-19]. miRNAs and lncRNAs are by far the best-studied ncRNAs. Recent data have demonstrated ncRNAs may play essential roles in the regulation of drug resistance in $\mathrm{BC}$, by controlling autophagy, drug efflux, drug targets, chromatin state, cell cycle, DDR, apoptosis, angiogenesis, cellular stemness, and EMT (Figure 1) [20-29]. ncRNAs have also been found in exosomes, wrapped in a lipid bilayer, which protects them from degradation [30]. ncRNAs are shuttled in this form between different cell types residing within TME, thereby acting as critical regulators of intercellular signaling in BC. Furthermore, exosomal ncRNAs are entirely functional in the recipient cells, where they orchestrate dramatic changes that may help in spreading the resistance (Figure 1) [31]. miRNAs and lncRNAs act as oncogenes or tumor suppressors in cancers, and due to their functionalities, are currently explored as prognostic biomarkers and targets for therapeutic interventions in BC [32]. 


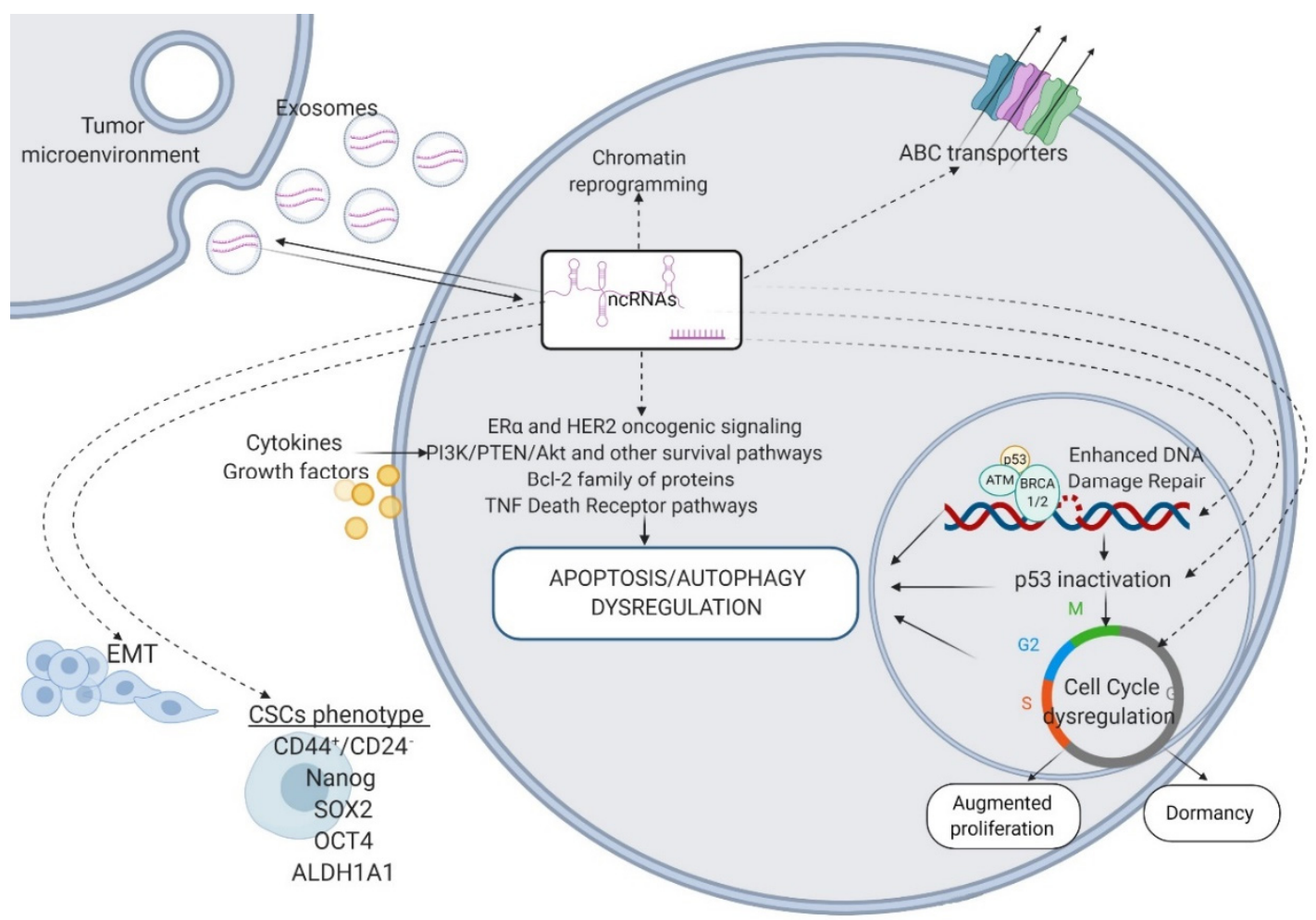

Figure 1. ncRNAs as key regulators of the mechanisms that render $\mathrm{BC}$ resistant to systemic therapies. ABC transporters-ATP-binding cassette transporters; Bcl-2-B-cell lymphoma 2; TNF-tumor necrosis factor; p53-tumor protein p53; ATM-Ataxia-Telangiectasia mutated; BRCA1/2—breast cancer 1/2; EMT-epithelial-mesenchymal transition; CSCs-cancer stem cells; CD44—cluster of differentiation 44; SOX2-SRY-Box Transcription Factor 2; OCT4-octamer binding transcription factor 4; ALDH1A1—aldehyde dehydrogenase 1 family member 1. Figure created with Biorender.com.

Here, we present a timely and detailed review of the latest research findings on the mechanisms that govern drug resistance acquisition in BC, focusing mainly on the regulatory roles of the aforementioned ncRNAs in these processes. Therefore, we consider that a comprehensive analysis of ncRNAs associated with drug resistance pathways is likely to provide new biomarkers for diagnosis and recurrence in $\mathrm{BC}$ patients, and potential targets for innovative therapeutic strategies.

\section{Current Therapeutic Strategies and Associated Drug Resistance Profiles in BC}

In BC clinical routine, the assessment of the immunohistochemical biomarkers (IHC), ER, progesterone receptor (PR), and HER2, altogether with the proliferation index (Ki67) is still the widely used protocol to determine the prognosis and eligibility for endocrine, targeted, or cytotoxic therapies [33].

ER is overexpressed in nearly $70 \%$ of BC patients, making them appropriate for endocrine therapies [34]. These therapies aim to disrupt the ER $\alpha$-associated transcriptional activities (selective ER modulators (SERMs), such as tamoxifen) and orchestrate ER degradation (estrogen receptor down regulators (SERDs), such as fulvestrant). Additionally, it can lower the estrogens levels in the body by interfering with their synthesis (aromatase inhibitors (AI), such as anastrozole and letrozole) (Figure 2) [35]. For more than 40 years, tamoxifen (TAM) has been the gold standard in treating both premenopausal and postmenopausal women with ER-positive tumors. Its use has significantly decreased the mortality and disease relapse rates by $30 \%$ and $50 \%$. However, $20-30 \%$ BC patients fail to respond to therapy, due to the intrinsic or extrinsic drug resistance, which often leads to metastatic disease and death [36]. The combined use of tamoxifen with AIs was shown to improve the therapeutic benefits in postmenopausal women, both in early and advanced stages [37]. However, the development 
of resistance to these first-line therapies remains a significant hurdle in BC management and calls for second-line therapies such as fulvestrant [38]. The dynamic interplay between ER signaling and important cell cycle regulators such as Cyclin-dependent kinase 4 and 6 (CDK4/6) has enabled the development of a new class of anticancer agents called CDK4/CDK6 inhibitors, which are extensively used in the treatment of metastasized ER-positive BC [39]. Their addition to traditional endocrine therapy, either in first-line or late-line setting has significantly improved the progression-free survival (PFS) and overall survival (OS) compared to endocrine therapy alone, in patients with metastatic ER-positive HER2-negative BC [40-42]; even so, their long-term efficiency seems to be also limited by the occurrence of drug resistance [43].

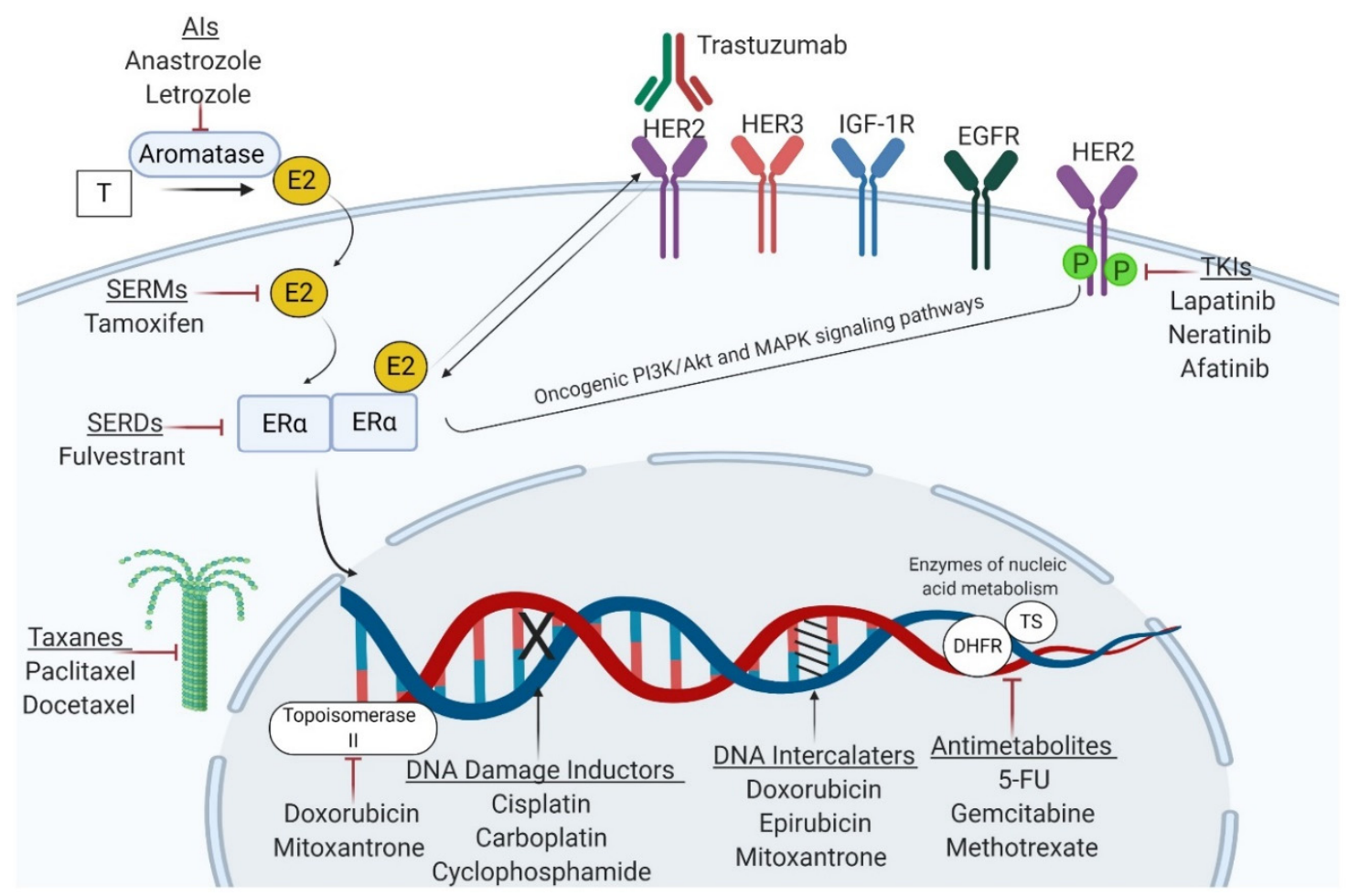

Figure 2. Mechanisms of action of the main classes of antineoplastic agents used in BC management. Endocrine therapies aim to interfere with $\mathrm{ER} \alpha$-associated signaling or decrease estrogen availability in the body, whereas trastuzumab and tyrosine kinase inhibitors (TKIs) are designed to block the HER2 receptor. Cytotoxic agents exert their anticancer effects through DNA damage (alkylating agents, platinum compounds), perturbation of nucleic acid synthesis (anthracyclines, taxanes, and mitoxantrone) or metabolism (antimetabolites). T—testosterone; E2—estradiol; ER $\alpha$-estrogen receptor $\alpha$; HER2 - human epidermal growth factor receptor 2; IGF-1R—insulin-like growth factor 1 receptor; EGFR - epidermal growth factor receptor; TKIs—tyrosine kinase inhibitors; SERMs—selective estrogen receptor modulators; SERDs-selective estrogen receptor degraders; 5-FU-5-fluorouracil; DHFR—dihydrofolate reductase; TS—-thymidylate synthetase. Figure created with Biorender.com.

Similar to ER, HER2 is an important prognostic biomarker and therapeutic target in BC [44]. The HER2 receptor is amplified in $20-30 \%$ of BC cases and is associated with poor prognosis and aggressive behavior [45]. Several therapeutic formulations have been developed against HER2 receptor and its associated signaling, including monoclonal antibodies trastuzumab and pertuzumab, and tyrosine kinase inhibitors, TKIs (lapatinib, neratinib, afatinib) (Figure 2) [46]. Although the addition of trastuzumab to chemotherapeutic regimens has greatly improved the overall survival (OS) of HER2 patients, its efficacy is questionable, since a significant number of patients fail to respond to this therapeutic approach [47]. Both ER-positive and HER2-positive BC may be approached with chemotherapy, which remains the mainstay in triple-negative BC (TNBC) [48]. 
TNBC, notorious for its high proliferative rate and distant metastatic patterns is usually addressed with chemotherapeutics, such as anthracyclines (doxorubicin/adriamycin, epirubicin), taxanes (paclitaxel, docetaxel), platinum compounds (cisplatin, carboplatin), antimetabolites (methotrexate, 5-fluorouracil, gemcitabine), and alkylating agents (cyclophosphamide). Several chemotherapeutics such as doxorubicin and mitoxantrone may interfere with the catalytic activity of Topoisomerase II. In contrast, others such as alkylating compounds and platinum salts may induce DNA alkylation and subsequently, DNA damage. Furthermore, taxanes exert their antineoplastic effects through microtubules stabilization, whereas anthracyclines and mitoxantrone intercalate into DNA to prevent mitosis. Additionally, antimetabolites exert their cytotoxic activities via regulating key enzymes involved in nucleic acid metabolism to inhibit DNA synthesis and transcription (Figure 2) [35,47,49]. It is documented that systemic therapies have an overall efficiency of $90 \%$ in primary tumors and $50 \%$ in metastases. After a certain time, the tumor becomes refractory to medication, leading to recurrent disease [10].

Recent data have partially revealed the mechanisms associated with treatment failure to the main classes of antineoplastic agents used in BC. In luminal tumors, in which endocrine modulators target ER-associated signaling, ER loss, ER-tyrosine kinases receptors (RTKs) crosstalk that results in the activation of several oncogenic signaling pathways, along with cell cycle dysregulation, are the most common mechanisms that render tumors resistant to hormone therapies [12,50]. Similarly, loss of HER2, alternative signaling through other RTKs such as insulin-like grow factor 1 receptor (IGF-1R) and epidermal growth factor receptor (EGFR) and mutations in downstream signaling elements that lead to the subsequent activation of cell survival mechanisms may orchestrate the development of anti-HER2 drugs resistance in HER2-enriched BC [51]. Additionally, chemotherapy resistance is associated with elevated drug efflux, apoptosis and autophagy dysregulation, cell cycle arrest, enhanced repair of damaged DNA, and EMT induction [52]. Furthermore, there is strong evidence that ncRNAs, especially miRNAs and lncRNAs, are actively involved in regulating treatment sensitivity to almost all the therapeutic approaches available in BC [53-59]. The particular involvement of these ncRNAs in different BC-drug resistance-associated mechanisms will be outlined below.

\section{3. miRNAs and BC Drug Resistance}

miRNAs are a class of small non-coding molecules (20-22 nucleotides in length) that fine-tune gene expression by binding to 3 'untranslated regions ( $3^{\prime}$ UTRs) of their target mRNAs, which results in translational repression or mRNA degradation [60]. The interaction of miRNA with a target transcript is mediated by a "seed sequence" of $2-8$ nucleotides termed miRNA responsive element (MRE). A single transcript can harbor multiple MREs, being regulated by many miRNAs. At the same time, one miRNA can have MREs in the mRNA of many genes [61,62]. In cancers, tumor-suppressive miRNAs, such as let-7, miR-15/16, miR 200, miR-203, and miR-205 have more than expected target genes, while well-known cancer genes contain more than expected MREs [63]. The altered genomic distribution of miRNA target sites is thought to be responsible for the complexity of functional regulatory networks reported in tumors. Moreover, various ncRNAs, including lncRNAs, also interact with miRNAs, acting like the so-called "miRNAs sponges". ncRNAs and mRNA share similar MREs and compete for a common pool of miRNAs, which results in modified mRNA translation and protein expression [62].

miRNAs biogenesis follows a multi-step process that includes the transcription, usually by RNA polymerase II, nuclear maturation and export, and formation of the effector miRNA-Argonaute complex termed as RNA-induced silencing complex (RISC) [30]. Nonetheless, certain miRNAs have been recently identified to be generated by alternative pathways that do not involve canonical components. These non-canonical miRNAs may have diverse origins and include Dicer-independent miRNAs, such as miR-451; miRtrons, which are DGCR8 Microprocessor Complex Subunit (DGCR8) and Drosha independent; simtrons, which are DGCR8, Dicer, Exportin-5, and Argonaute 2 (AGO2) independent, as well as snoRNA derived miRNAs and transfer RNA (tRNA) derived miRNAs [64,65]. As miRNAs 
regulate a plethora of cellular pathways, changes in biogenesis machinery may alter the expression and functionality of specific miRNAs, having important consequences in both health and disease [66-68]. miRNAs display increased evolutionary conservation and seem to be involved in the regulation of almost $60 \%$ of the protein-coding genes [69]. Interestingly, miRNAs have been found highly dysregulated in BC tissues compared to their matched normal counterparts [70,71]. Multiple lines of evidence suggest that they regulate almost all tumor biological properties, including the therapeutic response $[28,59,72-74]$. Notably, more than half of the miRNAs genes are located at fragile sites and cancer-associated genomic regions, suggesting a strong correlation between altered levels of miRNAs clusters and cancer biology [75]. However, the role of miRNAs in BC drug resistance to targeted, endocrine, and cytotoxic therapies will be outlined below.

\section{1. miRNAs Involved in BC Resistance to Endocrine Therapies}

Several studies investigated the correlation between estrogen resistance and miRNAs profiles in ER-positive BC cells in different experimental scenarios to provide a more accurate picture of the mechanisms underlying endocrine resistance in BC. For example, Ye and collaborators generated two tamoxifen (TAM)-resistant BC lines by two different administration methods: Michigan Cancer Foundation-7 C (MCF-7C) cell line via dose stepwise induction and MCF-7T cell line via temporal stepwise induction [76]. Therefore, the chemoresistance mechanisms displayed by MCF-7C would differ significantly from those activated in MCF-7T cells. Interestingly, the differential miRNAs profiles between TAM-sensitive (MCF-7) and TAM-resistant (MCF-7C, MCF-7T) BC cell lines analyzed by high-throughput RNA sequencing displayed differences in the levels of 118 miRNAs between MCF-7 and MCF-7C lines $(p<0.05)$, respectively, 42 miRNAs between MCF-7T and MCF-7 cells $(p<0.05)$. They also found that 75 miRNAs were increased, and 50 miRNAs were decreased significantly in MCF-7C versus MCF-7T cells. Additionally, Ye and colleagues pointed out that miR-21, miR-146a, miR-148a, miR-34a, and miR-27a may play essential roles in the acquisition of the TAM-resistant phenotype and become potential targets for TAM-resistant BC [76]. In parallel, Zhou and his team analyzed miRNAs expression profiles in fulvestrant and TAM-resistant tumors and found that miR-4532, miR-486-5p, miR-138, miR-1228, and miR-3178 may be promising candidates for reversing endocrine resistance in BC. They also showed that miR-3188, miR-21, miR-149 might be associated with fulvestrant resistance, while miR-342 and miR-1226 may promote TAM resistance [77]. Therefore, comparative analysis of these profiles may lead to a better understanding of the mechanisms underlying anti-estrogen resistance and may encourage the development of new targeted therapies that may be administered in conjunction with TAM or fulvestrant in BC.

Other studies have examined the involvement of individual miRNAs in resistance to endocrine therapies (Table 1). One of the pioneering studies in the field found that low levels of miR-342 may serve as a potential signature of TAM resistance in BC, being positively associated with $B C$ recurrence and metastasis. miR-342 acts as a tumor suppressor and can sensitize ER-positive tumors to endocrine therapy by regulating genes involved in cell death pathways, such as gem nuclear organelle associated protein 4 (GEMIN4) and bone morphogenetic protein 7 (BMP7) [78]. miR-320 is another tamoxifen sensitizer as this miRNA target cAMP-regulated phosphoprotein (ARPP-19) and estrogen-related receptor gamma (ERR $\gamma$ ), along with their downstream effectors c-Myc and Cyclin D1 [79]. Additionally, miR-451a was shown to restore TAM-MCF-7 sensitivity to tamoxifen by targeting 14-3-3 , a crucial factor that binds and protects proteins with critical roles in apoptosis and cell survival, including EGFR, HER2, $\beta$-catenin, and proto-oncogene serine/threonine-protein kinase (RAF-1). miR-451 induction inhibited EGFR, HER2, and mitogen-activated protein kinase (MAPK) signaling and enhanced apoptosis in TAM-resistant BC lines, suggesting that miR-451 may have therapeutic potential for ER-positive BC [80]. Additionally, miR-15a/16 may increase tamoxifen efficiency in BC via Cyclin E1 and B-cell lymphoma 2 (Bcl-2) modulation [81].

Among miRNAs with oncogenic functions in endocrine resistance is miR-21. This miRNA is involved in the development of resistance to almost all therapeutic approaches available in BC, 
including tamoxifen, fulvestrant, trastuzumab, and gemcitabine [82-84]. miR-21 is documented to be overexpressed in ER-positive BC lines and promote tamoxifen and fulvestrant resistance by targeting phosphatase and tensin homolog (PTEN) of the phosphatidylinositol 3-kinase/protein kinase $\mathrm{B}$ (PI3K/Akt) signaling pathway in BC [82]. Another study revealed that miR-221/222 released from TAM-MCF-7 could enter wild-type MCF-7 cells, endowing them with tamoxifen and fulvestrant refractoriness via p27 and ER $\alpha$ modulation, thereby enabling tumor growth in an ER-independent manner. One step further, pathway analysis elucidated that miR-221/222 transfer was correlated with the hyperactivation of several oncogenic pathways such as p53, transforming growth factor-beta (TGF- $\beta$ ), MAPK, Notch, ErbB, Janus kinase/signal transducers, and activators of transcription (Jak/STAT) signaling $[55,85]$. As an added complication, cancer-associated fibroblasts (CAFs) may also release miR-221-enriched exosomes to propagate fulvestrant resistance into tumor stroma in an interleukin (IL-6)-dependent manner [86]. Another oncogenic miRNA is miR-155, which was documented to promote tamoxifen resistance via Suppressor of Cytokine Signaling 6 (SOCS6) targeting the STAT3 pathway [87].

Table 1. miRNAs regulating endocrine resistance in $\mathrm{BC}^{1}$; (u) upregulated; (d) downregulated; (+) increase; (-) reduction.

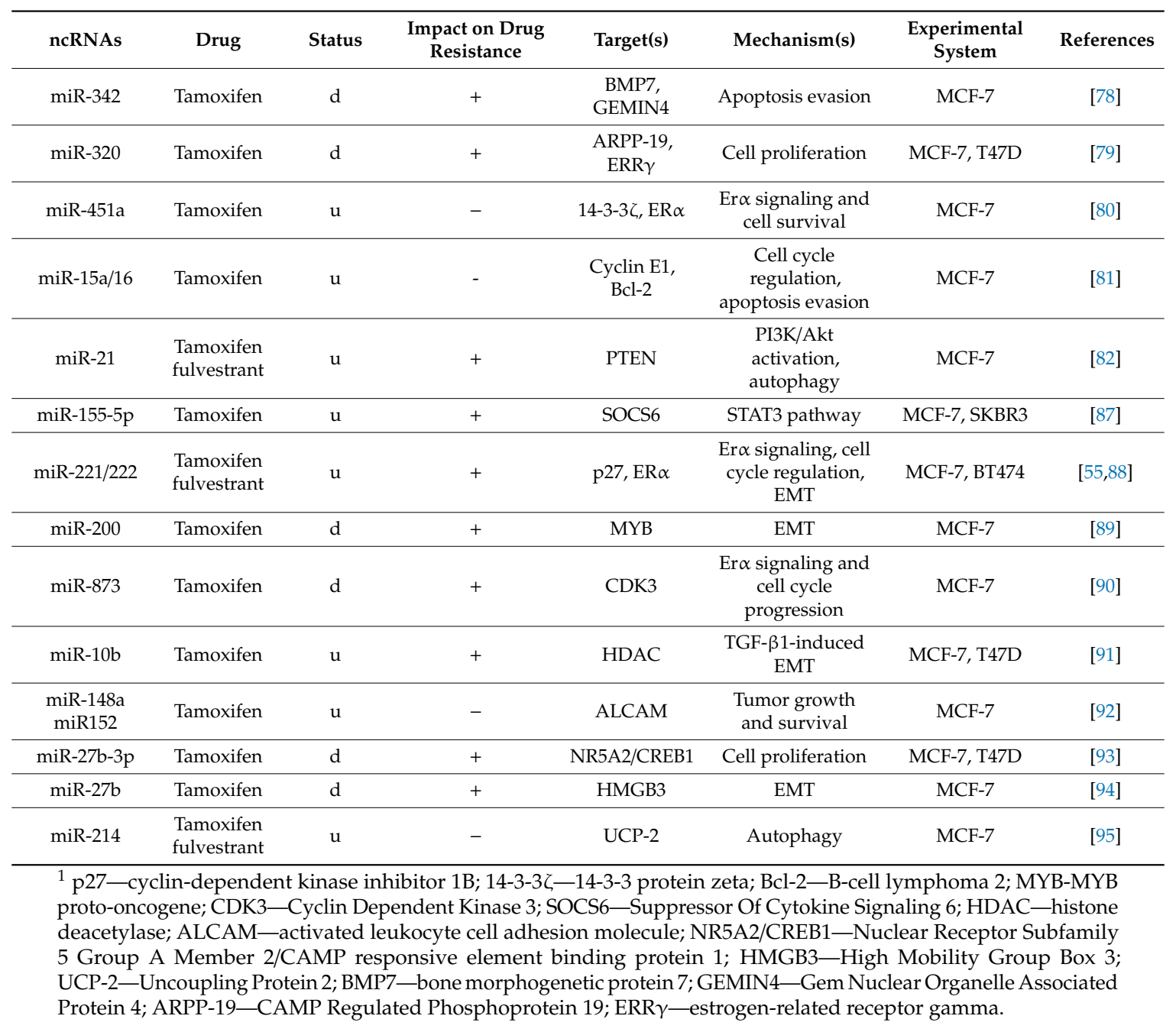

\section{2. miRNAs Involved in BC Resistance to Targeted Therapies}

Several studies have revealed a mechanistic link between miRNAs dysregulation and trastuzumab resistance in BC. For example, Yang and collaborators suggested that 48 miRNAs are upregulated, and 105 miRNAs are downregulated in trastuzumab-resistant JIMT-1 cells compared to their sensitive 
counterparts SKBR3. The cellular levels of seven miRNAs were further confirmed by qRT-PCR, and the Kyoto Encyclopedia of Genes and Genomes (KEGG) analysis revealed that they are mainly involved in the modulation of the PI3K/AKT pathway. They further used these seven miRNAs to construct a serum miRNAs signature that predicts trastuzumab response and found that miR-135b, miR-200b, and miR-29a are upregulated, whereas miR-224 is significantly downregulated in the plasma of the HER-2 enriched BC patients that do not benefit from trastuzumab [96]. Li and his team proposed another plasma miRNAs signature to distinguish between sensitive and non-sensitive trastuzumab patients. They suggested that miR-940 downregulation and miR-451a, miR-16-5p, and miR-17-3p overexpression are associated with increased trastuzumab efficiency [97]. Of particular importance, Di Cosimo and collaborators have recently reported that an increase in miR-148a-3p levels during trastuzumab administration is associated with an optimistic prognosis; additionally, the pathologic complete response (pCR) improved, even more, when miR-140-5p levels were concomitantly increasing [98].

However, other studies focused on the involvement of a particular miRNA in BC targeted-therapy resistance. Epigenetic silencing of miR-375 plays a crucial role in the development of trastuzumab resistance. It is associated with increased levels of its target IGF-1R, which may function as an alternative growth factor receptor in patients subjected to trastuzumab [99]. Another miRNA with a high affinity for IGF-1R is miR-630, found highly downregulated in HER2 metastatic and TKIs-resistant BC patients. Since miR-630 overexpression may restore sensitivity to HER2-targeted agents by attenuating tumor cell aggressiveness and motility, miR-630 can be regarded as a putative diagnostic and prognostic biomarker in lapatinib resistance but also as a therapeutic alternative in removing TKIs resistance in BC [100]. Another miRNA involved in trastuzumab resistance is miR-210, which regulates the transcription factor E2F3 and the DNA repair enzyme RAD52 to support tumor growth and dissemination upon previous treatment exposure [101,102]. miR-21 and miR-221 are other two oncogenic miRNAs that promote trastuzumab resistance via PTEN silencing and subsequent PI3K/Akt signaling hyperactivation $[103,104]$.

In contrast, miR-16 acts as a tumor suppressor and can restore trastuzumab and lapatinib sensitivity by suppressing Cyclin J (CCNJ) and Far Upstream Element Binding Protein 1 (FUBP1) in resistant $\mathrm{BC}$ [105]. The exosomal transfer of miR-567 was recently reported to reverse trastuzumab resistance in BC via Autophagy related 5 (ATG5) inhibition; thereby, its therapeutic addition may considerably improve and enhance patients' responsiveness to this drug [106]. Other miRNAs with oncogenic or tumor suppressor functions in anti-HER2 drug resistance can be found in Table 2.

Of particular importance, miR-205 has been proved to play antithetical roles in regulating the response to targeted therapies in BC. miR-205 has been consistently reported downregulated in mammary carcinomas versus normal breast tissues. It emerged as an onco-suppressive miRNA due to its ability to suppress several notorious oncogenes, such as ErbB3 and Zinc Finger E-Box Binding Homeobox 1 (Zeb1). Cataldo and his team confirmed the tumor-suppressive function of miR-205 in HER2-positive BC cell lines, as its ectopic expression improved trastuzumab effectiveness in vitro through the impairment of Akt signaling pathway [26]. Surprisingly, De Cola et al. found that miR-205 was upregulated in HER2-positive patients derived-breast cancer stem cells, and its increased levels promoted targeted therapy resistance via downregulating ERBB2 and EGFR in a p63-dependent manner [24]. The different functions exerted by miR-205 in this clinical setting suggest that developing an appropriate strategy in removing drug resistance is not as straightforward as some researchers postulated in their studies. 
Table 2. miRNAs involved in targeted therapy resistance in $\mathrm{BC}^{1}$; (u) upregulated; $(\mathrm{d})$ downregulated; $(+)$ increase; $(-)$ reduction.

\begin{tabular}{|c|c|c|c|c|c|c|c|}
\hline ncRNAs & Drug & Status & $\begin{array}{c}\text { Impact on Drug } \\
\text { Resistance }\end{array}$ & Target(s) & Mechanism(s) & $\begin{array}{l}\text { Experimental } \\
\text { System }\end{array}$ & References \\
\hline miR-205-5p & Trastuzumab & $\mathrm{u}$ & + & ERBB2, EGFR & Cell survival & BCSCs & [24] \\
\hline miR-205 & Trastuzumab & $\mathrm{u}$ & - & NA & Akt impairment & SKBR3 & [26] \\
\hline mir-375 & Trastuzumab & $\mathrm{u}$ & - & IGF1R & Cell survival & SKBR3 & [99] \\
\hline miR-630 & $\begin{array}{l}\text { Lapatinib } \\
\text { neratinib } \\
\text { afatinib }\end{array}$ & $\mathrm{u}$ & - & IGF1R & Cell survival & $\begin{array}{c}\text { SKBR3, } \\
\text { HCC1954 }\end{array}$ & [100] \\
\hline miR-210 & Trastuzumab & $\mathrm{u}$ & - & E2F3, RAD52 & $\begin{array}{l}\text { DNA damage } \\
\text { repair and cell } \\
\text { proliferation }\end{array}$ & $\begin{array}{l}\text { BT474, patient } \\
\text { serum }\end{array}$ & {$[101,102]$} \\
\hline miR-21 & Trastuzumab & $\mathrm{u}$ & + & PTEN, PDCD4 & $\begin{array}{c}\text { PI3K/Akt } \\
\text { activation, EMT } \\
\text { and inflammatory } \\
\text { signals }\end{array}$ & $\begin{array}{c}\text { SKBR3, BC } \\
\text { patient tissues }\end{array}$ & [103] \\
\hline miR-221 & Trastuzumab & $\mathrm{u}$ & + & PTEN & $\begin{array}{c}\text { PI3K/Akt/mTOR } \\
\text { pathway }\end{array}$ & SKBR3 & [104] \\
\hline miR-16 & $\begin{array}{l}\text { Trastuzumab } \\
\text { lapatinib }\end{array}$ & $\mathrm{u}$ & - & CCNJ, FUBP1 & $\begin{array}{l}\text { Cell proliferation } \\
\text { and survival }\end{array}$ & $\begin{array}{c}\text { BT474, SKBR3, } \\
\text { HCC-1569, } \\
\text { MDA-MB-453 }\end{array}$ & [105] \\
\hline miR-567 & Trastuzumab & $\mathrm{d}$ & + & ATG5 & Autophagy & SKBR-3, BT474 & [106] \\
\hline miR-200c & Trastuzumab & $\mathrm{u}$ & - & ZNF217, ZEB1 & $\begin{array}{c}\text { TGF- } \beta \\
\text { signaling-induced } \\
\text { EMT }\end{array}$ & SKBR3 & [107] \\
\hline miR-7 & Trastuzumab & $\mathrm{u}$ & - & $\begin{array}{c}\text { EGFR, Src } \\
\text { kinase }\end{array}$ & $\begin{array}{l}\text { ERBB2-driven } \\
\text { proliferation }\end{array}$ & MCF-7 & [108] \\
\hline
\end{tabular}

\section{3. miRNAs Involved in BC Chemoresistance}

Several miRNAs have been documented to act on ATP-binding cassette (ABC) transporters, which may confer chemoresistance in cancers by pumping the drugs out of the cell, thereby decreasing their intracellular concentration. As these membrane transporter proteins may act on various substrates, they have been inherently associated with the acquisition of multidrug resistance (MDR) phenotype in BC [109]. Multidrug resistance protein 1/P-glycoprotein (MRP1/P-gp), the archetypal representative of this family, is actively involved in BC cancer refractoriness to a variety of compounds, including anthracyclines, platinum agents, and taxanes [110]. P-gp overexpression resulting from decreased miR-451 levels is associated with anthracycline resistance in MCF-7 cells [111]. Interestingly, miR-302a/b/c/d has been shown to reverse the MDR phenotype in BC cells by indirectly repressing P-gp following Mitogen-activated protein kinase kinase kinase 1 (MEKK1) targeting in the extracellular-signal-regulated kinase (ERK) pathway [25]. MRP pumps, which act on similar substrates as P-gp, are also subject to miRNA regulatory action. For instance, loss of miR-7 and miR- 345 have been documented to contribute to MRP1-mediated cisplatin resistance in BC, whereas the reinforcement of these two miRNAs sensitized ER-positive BC cell lines to platinum agents [53]. Additionally, miR-489 increased BC therapeutic response to doxorubicin and cisplatin by reducing MRP-2 levels, a recurrent transporter found in platinum-resistant cells [53]. Other miRNAs associated with chemoresistance, including ABC-transporter mediated resistance may be found in Table 3.

Many chemotherapeutic agents used in BC, such as platinum compounds and alkylating agents exert their antineoplastic effects through DNA damage. Indeed, several pathways are activated in response to genotoxic stress, including cell cycle arrest and DDR [33]. Of particular interest, certain miRNAs that act on genes involved in cell cycle control and DNA repair have been proposed to serve as potential biomarkers for prognosis and therapeutic response in $\mathrm{BC}$ patients. For example, miR-34a may downregulate Bcl-2 and attenuate Cyclin-D1-G1-induced arrest to promote docetaxel 
resistance in mammary carcinomas [54]. Additionally, low levels of miR-302b have been shown to promote cisplatin resistance via E2F1 and DDR upregulation in BC [112]. Interestingly, the miR-449 family has been shown to regulate several genes involved in cell proliferation, such as E2F1, E2F3, and Cyclin-dependent kinase 2 (CDK2) to enhance doxorubicin cytotoxicity in TNBC cell lines [113]. Moreover, miR-638 and miR-218 can target Breast Cancer 1 Gene (BRCA1) and interfere with tumor cells' abilities to repair cisplatin-induced DNA damage, increasing the efficiency of platinum salts in BC $[114,115]$.

Apoptosis avoidance is also a ubiquitous phenomenon in non-responsive breast tumors, and many authors have potentiated a mechanistic link between miRNAs and apoptosis deregulation in BC (Table 3). Overexpression of miR-29a and miR-222 was associated with BC anthracycline and taxane resistance, through PTEN downregulation and the subsequent activation of the Akt/mTOR signaling pathway [116]. Low levels of miR-205 were also reported in BC resistant to docetaxol, doxorubicin, and cyclophosphamide regimens. Notably, miR-205 induction was found to downregulate vascular endothelial growth factor A (VEGFA), and fibroblast grow factor-2 (FGF2), which results in impaired PI3K/Akt signaling and increased apoptosis upon chemotherapy [27]. miR-100 is also downregulated in drug-resistant $\mathrm{BC}$, and its forced expression was proved to sensitize tumors to paclitaxel by targeting mTOR and its associated signaling [117]. miR-542-3p is another biomarker of paclitaxel sensitivity in $\mathrm{BC}$ and has been documented to act on the antiapoptotic protein survivin leading to attenuated HER3/PI3K/Akt signaling, which enhanced paclitaxel cytotoxic activity in HER2-positive tumors [118]. miRNAs also exert their pro- or antiapoptotic activities downstream of the Akt pathway. For example, Bcl-2 overexpression due to low levels of miR-451 [119], miR-181a [120], miR-424/322, and miR-503 [121] can counteract chemotherapy induced apoptosis resulting in limited therapeutic efficiency, disease relapse, and metastasis. Additionally, miR-221 [122] and miR-944 [123] were found to prevent BC from undergoing apoptosis and instigate cisplatin resistance through direct repression of Bcl-2-like protein 11 (Bim) and BCL2/adenovirus E1B $19 \mathrm{kDa}$ protein-interacting protein 3 (Bnip-3), respectively. In contrast, miR-31 was shown to render $B C$ more vulnerable to medication via Bcl-2 downregulation following Protein Kinase C Epsilon (PKCE) targeting in the STAT3 pathway [124]. Interestingly, miRNAs can also act on molecules involved in the final stages of apoptosis, such as caspases to regulate the apoptotic response in BC. One such miRNA is let-7, which has been confirmed to attenuate doxorubicin-induced apoptosis through translational repression of effector caspase-3, a master regulator of programmed cell death [125].

miRNAs can also modulate the therapeutic response via regulating autophagy (Table 3). A recent study revealed that isoliquiritigenin, a natural flavonoid has the property to suppress miR-25a and induce autophagic cell death in BC drug-resistant tumors both in vivo and in vitro. Further analysis potentiated that miR-25a inhibition leads to the amplification of its target Unc-51 like autophagy activating kinase 1 (ULK), which may restore doxorubicin sensitivity through ABCG2 degradation via the autophagy-lysosome axis [126]. Similarly, miR-489 can increase doxorubicin efficiency in BC by blocking autophagy as an alternative survival mechanism under stressful conditions [28]. Additional studies revealed ULK1 and lysosomal transmembrane protein 4 beta (LAPTM4B) as direct targets of miR-489 [28]. Currently, the mechanistic link between miRNAs and autophagy in BC chemoresistance is extensively investigated, as it may reveal new therapeutic strategies for approaching $\mathrm{BC}$ resistant tumors.

The presence of breast cancer stem cells (BCSCs), a minor population from the tumor bulk that displays stem cell properties, is another crucial determinant of chemoresistance in BC. BCSCs refractoriness to conventional therapies may be partially attributed to their quiescent phenotype which is inappropriately addressed with antiproliferative chemotherapy; however, in recent years, a strong relationship between miRNAs and the regulation of CSCs features including tumorigenic potential, pluripotency, and EMT with severe implications in therapeutic response has been described [33]. Thereby, understanding the miRNAs involved in CSCs regulation may reveal new therapeutic approaches to circumvent the chemoresistance hurdle in BC. In doxorubicin- and cisplatin-resistant 
TNBC cells, miR-137 is overexpressed and leads to increased levels of its target gene Follistatin-related protein 1 (FSTL1), which seems to be involved in stemness maintenance and chemoresistance via Wnt/ $\beta$-catenin signaling modulation [29]. miR-140-5p may also act on the Wnt/ $\beta$-catenin pathway to suppress the self-renewal potential and tumorigenicity of BCSCs while restoring the sensitivity of tumors to anthracyclines [127]. Furthermore, low levels of miR-155 sensitized tumors to doxorubicinol by modulating several markers associated with BCSCs phenotype, including CD44, CD90 cell surface biomarkers, and ABCG2 protein transporter [128]. The overexpression of drug transporter proteins and pro-apoptotic proteins in the mitochondrial pathway is another common mechanism exploited by CSCs to prevent chemotherapy-induced apoptosis [33]. For instance, miR-519d was found profoundly downregulated in BCSCs, and its forced induction restored cisplatin sensitivity via pro-apoptotic Bcl-2 family protein myeloid cell leukemia 1 (MCL-1) modulation (Table 3) [129].

EMT, the process by which non-motile epithelial cells from the primary site acquire migratory and invasive potential and become mesenchymal cells, is also documented to provide cells with CSCs properties and affect the patient's prognosis [130]. miR-21 can orchestrate EMT and hypoxia-inducible factor 1-alpha (HIF-1 $\alpha$ ) activation, increasing the invasiveness and adaptability of third-sphere, forming BCSCs-like to hypoxic conditions [21]. Notably, low levels of miR-30c may promote BC chemoresistance via overexpression of EMT-related cytokines Twinfilin 1 (TWF1) and IL-11 [131]. Moreover, miR-155 delivered by exosomes augmented EMT and conferred chemoresistance to recipient $\mathrm{BC}$ cells, by regulating at least five genes: adenomatous polyposis coli (APC), Hydroxysteroid 17-Beta Dehydrogenase 12 (HSD17B12), MYC, Mothers against decapentaplegic homolog 1 (SMAD1), and SMAD3 [132]. Additionally, miR-155 has been described downregulate CCAAT/enhancer-binding protein beta (C/EBP- $\beta)$, which resulted in TGF- $\beta$-induced EMT, metastasis, and indeed, chemoresistance [74]. miR-200c, highly underexpressed in BC and associated with aggressive behavior, has been indicated to act on B lymphoma Mo-MLV insertion region 1 homolog (BMI), leading to EMT activation and increased tumorigenicity [133]. Interestingly, the induction of miR-200c in claudin-low tumors, which primarily express EMT and CSCs features significantly reduced chemoresistance via colony-forming capacity downregulation and EMT disruption, providing a promising therapeutic strategy for highly aggressive TNBC tumors [134]. All this information offers valuable insights into the impact of miRNome on the properties of CSCs and can be exploited for forecasting or developing theranostic strategies to combat the drug-resistance phenotype in BC.

Another factor influencing the sensitivity of cancers to chemotherapy results from their interaction with the local microenvironment [33]. Mainly, BCSCs can transfer exosomal miRNAs to neighboring sensitive cells, and it may have a tremendous impact on metastasis, tumor growth, and therapeutic response. For example, miR-222 enriched exosomes of doxorubicin-resistant MCF-7 cells transferred the chemoresistance to sensitive cells through negative regulation of PTEN [135]. Similarly, TNBC cells derived exosomal miR-1246 were shown to enhance Human Mammary Epithelial (HMLE) cell line proliferation, migration, and multidrug resistance via Cyclin G2 (CCNG2) downregulation [136]. Tumor-associated macrophages (TAM) can also take up miR-770 from TNBC tumor cells, and further analysis revealed that miR-770 negatively regulates gene coding for Stathmin 1 (STMN1). STMN1 is also known as metablastin and oncoprotein 18, triggering M1 polarization of macrophages and EMT disruption, which further results in increased sensibility to doxorubicin [137]. BC cell dormancy in the bone marrow (BM) is also associated with chemoresistance in BC, and exosomal miRNAs transfer appears to play crucial roles in this process [138,139]. For example, in a coculture system, BM-mesenchymal stem cells (MSCs) can deliver miR-23b to BC cells, triggering quiescence by suppressing the target gene myristoylated alanine-rich $C$ kinase substrates (MARCKS), involved in cell cycle progression and motility [140]. Similarly, MSCs-derived miR-222/miR-223 can induce dormancy and chemoresistance in neighboring tumor cells, but the mechanisms involved remain to be elucidated [141]. 
Table 3. miRNAs regulating BC chemoresistance ${ }^{1}$; (u) upregulated; (d) downregulated; (+) increase; $(-)$ reduction.

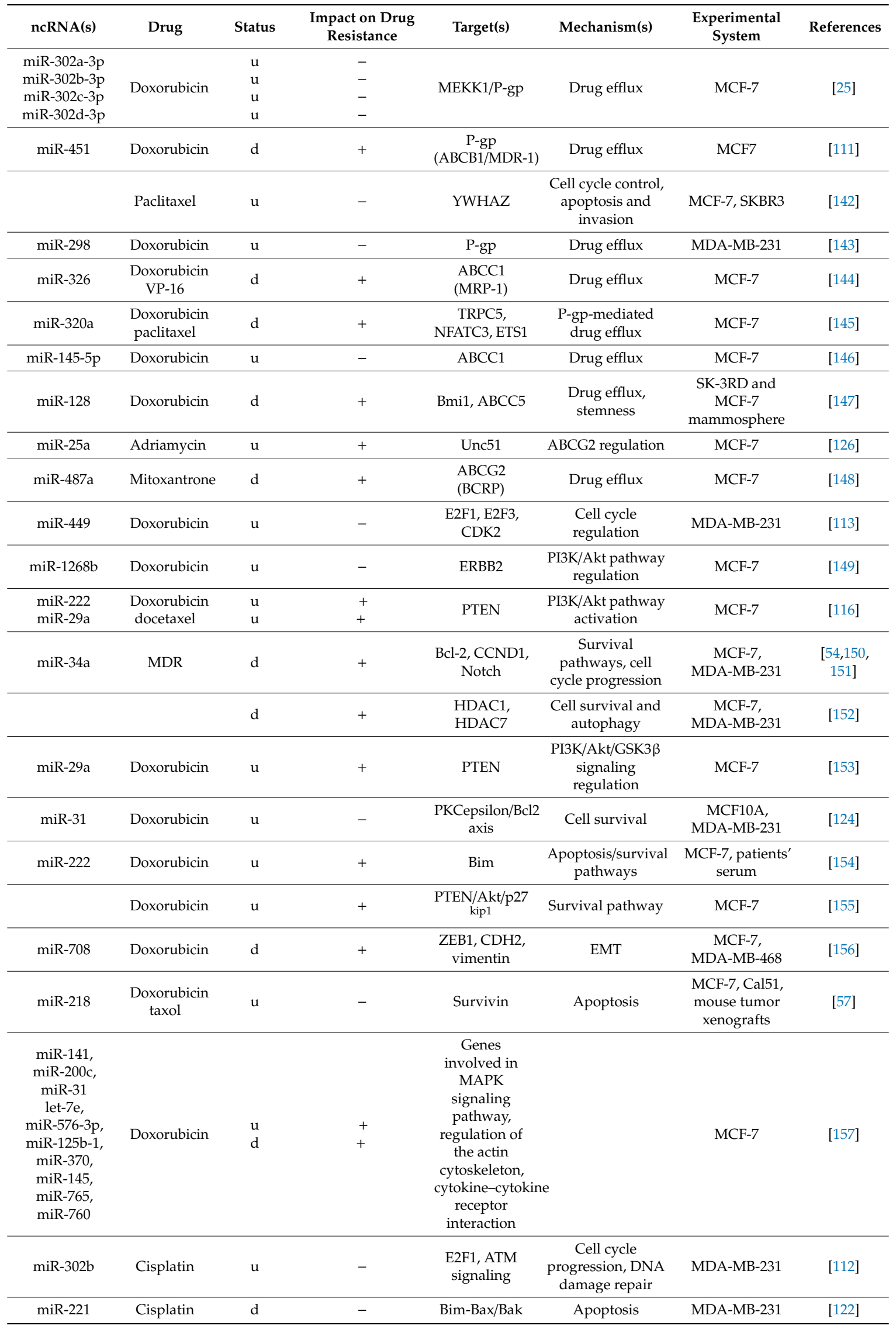


Table 3. Cont

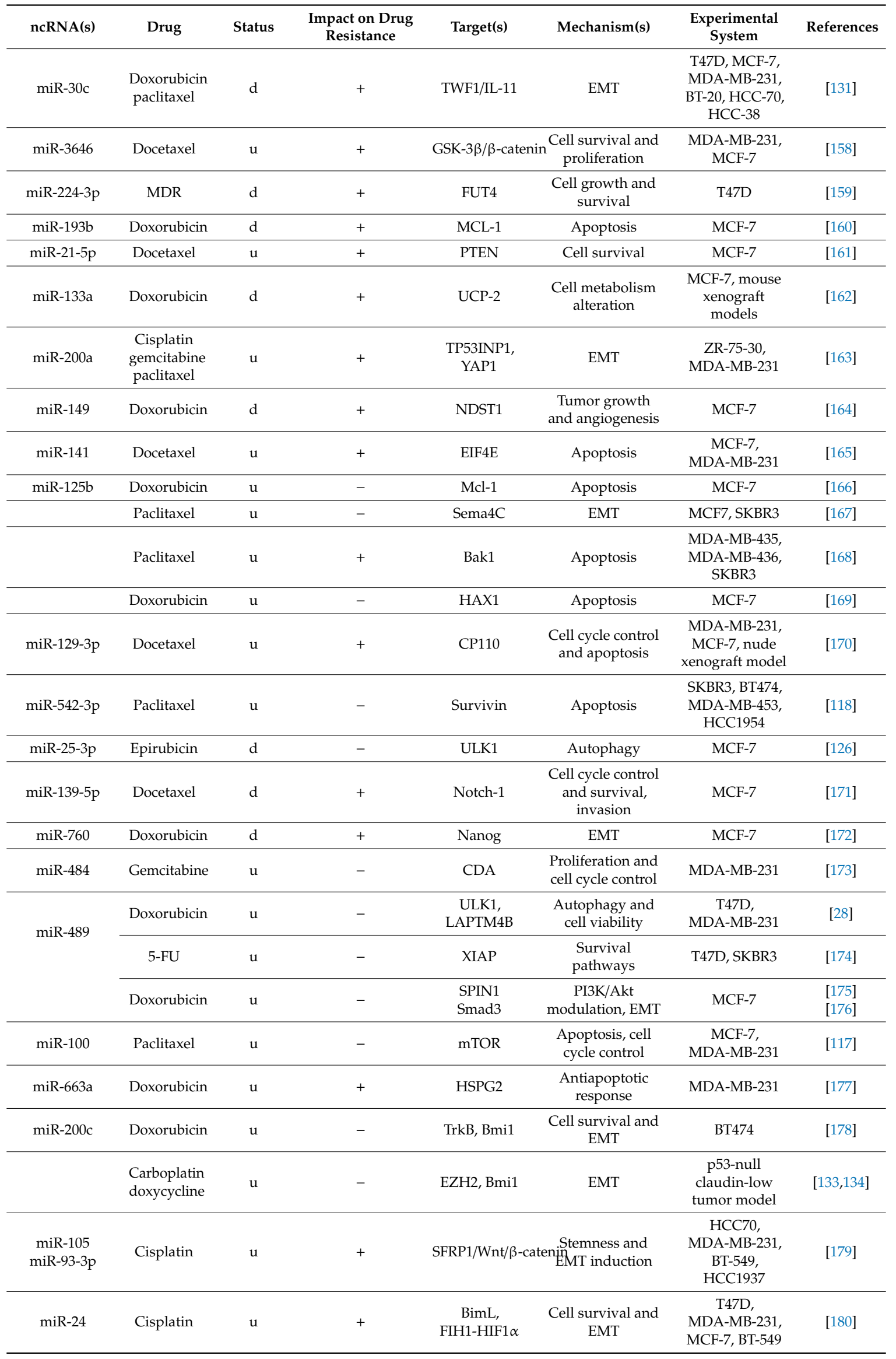


Table 3. Cont.

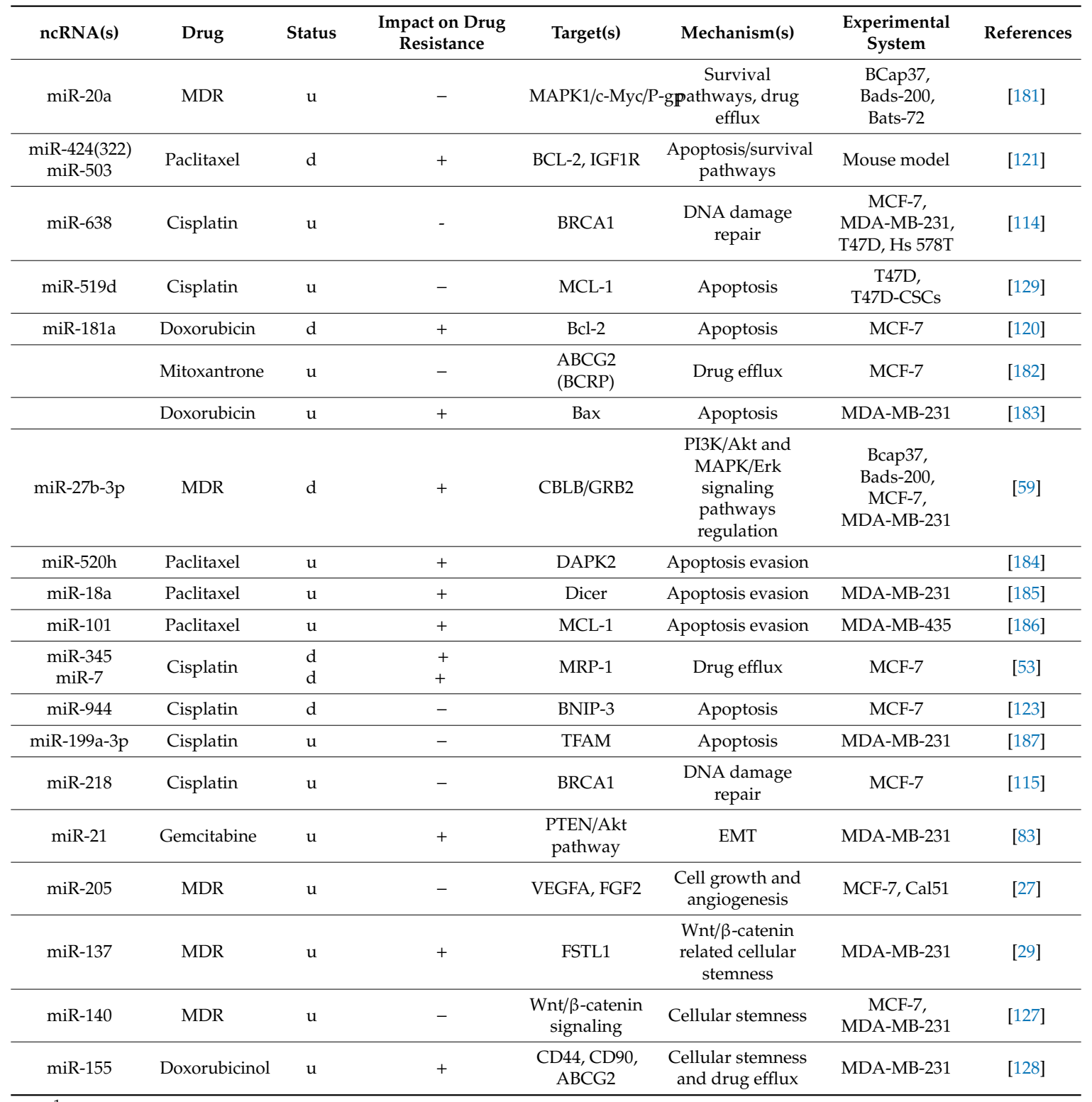

${ }^{1}$ YWHAZ-14-3-3 protein zeta/delta; CCND1-Cyclin D1; HDAC-Histone Deacetylase 1; Bim-Bcl-2-like protein 11; ATM-ataxia telangiectasia mutated; TWF1—Twinfilin Actin Binding Protein 1; IL11—interleukin 11; GSK-3ß-glycogen synthase kinase 3 beta; FUT4-Fucosyltransferase 4; UCP2-Uncoupling Protein 2; TP53INP1-Tumor Protein P53 Inducible Nuclear Protein 1; YAP1-Yes Associated Protein 1; CDH2-Cadherin 2; EIF4E-Eukaryotic Translation Initiation Factor 4E; NDST1-N-Deacetylase And N-Sulfotransferase 1; CP110—centriolar coiled coil protein 110; Sema4C—Semaphorin 4C; Bak1-Bcl2 antagonist/killer 1; Hax1-HCLS1-associated protein X-1; TRPC5-Transient Receptor Potential Cation Channel Subfamily C Member 5; NFATC3-Nuclear Factor Of Activated T Cells 3; ETS1-ETS Proto-Oncogene 1; ULK1/LAPTM4B-Unc-51-like kinase 1/Lysosomal Protein Transmembrane 4 Beta; CDA—cytidine deaminase; XIAP-X-Linked Inhibitor Of Apoptosis; HSPG2-Heparan Sulfate Proteoglycan 2; TrkB-tropomyosin receptor kinase B; Bmi-1-BMI1 Proto-Oncogene/Polycomb Ring Finger protein; FIH1-factor inhibiting hypoxia-inducible factor 1 alpha; HIF1 $\alpha$-hypoxia-inducible factor-1 alpha; TFAM — Transcription Factor A, Mitochondrial; FSTL1—follistatin-related protein 1.

\section{IncRNAs in BC Drug Resistance}

Recently, another class of ncRNAs, the lncRNAs have gained tremendous attention because of their multilayered regulatory activities. Unlike endogenous miRNAs, IncRNAs are RNA transcripts that extend over 200 nucleotides, abundant in the human genome and with high tissue specificity $[188,189]$. Recent evidence highlighted that core promoter sequences play key roles in regulating transcript tissue specificity. Briefly, increased tissue specificity is associated with less transcription factor (TF) motifs 
at the core promoter [190,191]. Interestingly, the tissue/stage/subtype-specific expression of lncRNAs positions them as promising prognostic and diagnostic biomarkers, as well as therapeutic targets for a variety of pathologies [192].

Based on their localization within the protein-coding genes, lncRNAs can be classified into five subtypes: sense lncRNAs, antisense lncRNAs, intergenic or intronic transcripts, and bidirectional lncRNAs [193]. IncRNAs have a complex structure (secondary or tertiary) that allows them to interact with various molecules such as DNA, mRNA, other ncRNAs (e.g., miRNAs), and proteins. This may be why lncRNAs are actively involved in gene regulation, modulating vital cellular processes such as chromatin reprogramming, transcription, post-transcriptional processing, and translation $[20,188,194]$. However, based on their functionalities, they have been divided into four archetypes: (1) signals, (2) decoys, (3) guides, and (4) ropes [195]. lncRNA biogenesis is similar to that of miRNAs, being transcribed by RNA polymerase II. lncRNAs are spliced, capped, and polyadenylated and usually transported to the cytoplasm. However, lncRNAs reside and operate both in the nucleus and in the cytoplasmic compartment. Nuclear lncRNAs may exert their cis- and trans-regulatory activities by regulating gene expression at local or distal sites. In contrast, cytosolic lncRNAs can act as competitive endogenous RNAs (ceRNAs), sequestrating miRNAs, and subsequently influence the expression of different miRNA-target genes [196].

Currently, over 30,000 transcripts have been identified and annotated within the human genome, and their number is expected to increase over time [197]. Due to their heterogeneity and abundance, lncRNAs are poorly characterized, compared to sncRNas. However, what was once considered "transcriptional noise" now has well-defined roles in different cell types and organisms. Studies have shown that lncRNAs strictly regulate physiological processes and that their expression profiles are highly dysregulated in cancers, including BC [198-200]. The deregulation of the transcriptomic landscape may have severe implications for metastasis, tumor growth, and, indeed, response to medication [201-203]. Herein, we will focus mainly on the lncRNAs involved in modulating susceptibility to conventional therapies in BC.

\subsection{IncRNAs and BC Resistance to Endocrine Therapy}

Regarding the involvement of lncRNAs in resistance to endocrine therapies, most of the molecules identified so far have been associated with tamoxifen resistance, as it is the gold standard in the treatment of ER-positive BC.

A recent article proposed an 11 lncRNAs-based tool for estimating the risk of relapse among ER-positive BC patients addressed with tamoxifen. The increased expression of RP11.259N19.1, KB.1460A1.5, and PP14571, along with low levels of PTEN-induced kinase 1 (PINK1) Antisense RNA (PINK1.AS), KLF3 antisense RNA 1 (KLF3.AS1), Long Intergenic Non-Protein Coding RNA 00,339 (LINC00339), LINC00472, Retinitis pigmentosa-11.351I21.11 (RP11.351I21.11), PKD1P6.NPIPP1, PDCD4 Antisense RNA 1 (PDCD4.AS1), KLF3 antisense RNA 1 (KLF3.AS1), PP14571, and RP11.69E11.4 were associated with an increased risk of recurrence in tamoxifen-resistant BC, and the 3/5 year survival rates further confirmed this in clinical cohorts. However, no significant association was reported between the expression levels of these lncRNAs and clinic-pathological factors. Interestingly, pathway analysis performed on the 11 tamoxifen resistance-related lncRNAs highlighted Akt and Wnt signaling as the most prominent pathways in this clinical setting [204]. Evidence regarding lncRNAs involvement in endocrine resistance also comes from individual studies, and the scientific efforts made so far have resulted in the identification of at least five oncogenic lncRNAs (HOTAIR, BCAR4, UCA1, CCAT2, ROR) and a single suppressor tumor, GAS5 in the clinical setting of BC endocrine therapy resistance (Table 4).

HOX antisense antigenic RNA (HOTAIR) is an oncogenic lncRNA able to recruit Polycomb Repressive Complex 2 (PRC2) and Lysine-specific demethylase 1 (LSD1) complex to promote carcinogenesis and metastasis in many cancers, including BC [20,194]. Enhanced expression of lncRNA HOTAIR was shown to support tamoxifen resistance in BC through direct interaction with 
$\mathrm{ER} \alpha$, which resulted in the amplification of ER-associated transcriptional programs even in the absence of estrogens [205]. The newly discovered HOX antisense intergenic RNA myeloid 1 (HOTAIRM1) was also associated with tamoxifen resistance via HOXA genes modulation [206]. HOTAIRM1 and HOXA1 were found overexpressed in tamoxifen-resistant tumors, and their silencing led to increased therapeutic response. Subsequent studies have shown that HOTAIRM1 is capable of interacting with the Enhancer of zest homolog 2 (EZH2) of PRC2 and prevent the deposition of H3K27me3 marks at the HOXA1 promoter, thereby increasing HOXA1 levels in tamoxifen-resistant BC cells. Therefore, HOTAIRM1 and HOXA1 may serve as promising targets in ER-positive patients who have acquired tamoxifen resistance [206].

Overexpression of Breast Cancer Anti-Estrogen Resistance 4 (BCAR4), associated with rapid disease progression and poor prognosis, has also been proposed as a signature of tamoxifen resistance in BC. It was found that BCAR4 stimulates the phosphorylation of v-erb-b2 erythroblastic leukemia viral oncogene homologs (ERBB2) and ERBB3, together with their downstream regulators AKT and extracellular signal-regulated kinase 1/2 (ERK1/2) [207]. siRNA-mediated reduction of ERBB2 and ERBB3 blocked BCAR4-driven proliferation, confirming the crucial role of this lncRNA in tamoxifen resistance in $\mathrm{BC}$. Interestingly, the addition of lapatinib to antiestrogenic regimens has proven to be an effective strategy in BCAR4-driven ER-positive breast tumors, since lapatinib can disrupt ERBB2 phosphorylation and the stimulation of its downstream mediators AKT, FAK, SHC, STAT5, and STAT6. However, a group of BCAR4-positive/ERBB2-low-expressing BC patients eligible for tamoxifen and lapatinib regimens has been shown not to benefit entirely from this therapy, suggesting that BCAR4 silencing may be a useful therapeutic approach just in certain subgroups of resistant BC [208]. Colon Cancer Associated Transcript 2 (CCAT2), another oncogenic lncRNA that controls tumor growth and dissemination by modulating Wnt and TGF- $\beta$ signaling in BC, has been found in increased levels in tamoxifen-resistant BC $[209,210]$. CCAT2-mediated drug resistance was further documented to be supported by ERK/MAPK signaling, and the silencing of either ERK/MAPK and CCAT2 resulted in increased apoptosis and necrosis in tamoxifen-resistant BC [211]. lncRNA regulator of reprogramming (ROR) is also associated with enhanced proliferation, invasion, and hormone therapy resistance in BC via regulation of the miR-205-5p/ZEB1/ZEB2 axis [202]. Alternatively, lncRNA ROR was shown to regulate MAPK/ERK signaling to confer estrogen-independent and cell growth in BC [212].

lncRNA Urothelial Carcinoma Associated 1 (UCA1) is also overexpressed in tamoxifen-resistant BC cell lines and its silencing results in G2/M arrest, enhanced apoptosis, and increased sensitivity to anti-estrogens. It was further shown that UCA1 binds to the homologous enhancer of zeste 2 $(\mathrm{EZH} 2)$ of the p21 promoter and downregulates the p21 gene; however, further studies have shown that UCA1-mediated tamoxifen resistance relies on the PI3K/Akt pathway [213]. Beside AKT/mTOR signaling, UCA1 was documented to regulate the $\mathrm{Wnt} / \beta$-catenin pathway in hormonotherapy-resistant BC $[214,215]$. On another mechanism, UCA1 acts as a molecular sponge for miR-18 and promotes BC drug resistance by attenuating the inhibitory effects of miR-18 on HIF1 $\alpha$ expression [216]. Last but not least, the transfer of UCA1-enriched exosomes from tamoxifen-resistant to tamoxifen-sensitive BC cells resulted in enhanced proliferation and decreased levels of cleaved caspase- 3 and apoptosis in the recipient cells. It was further confirmed that exosomes with impaired UCA1 transferred to MCF-7 cells could not render tumors refractory to drugs, suggesting that UCA1 knockdown may be an effective strategy to overcome tamoxifen resistance in BC [217]. 
Table 4. Oncogenic and tumor suppressor lncRNAs associated with BC endocrine resistance ${ }^{1}$; $(\mathrm{u})$ upregulated; (d) downregulated; (+) increase; (-) reduction.

\begin{tabular}{|c|c|c|c|c|c|c|c|}
\hline ncRNA(s) & Drug & Status & $\begin{array}{c}\text { Impact on Drug } \\
\text { Resistance }\end{array}$ & Target(s) & Mechanism(s) & $\begin{array}{l}\text { Experimental } \\
\text { System }\end{array}$ & References \\
\hline ROR & Tamoxifen & $\mathrm{u}$ & + & $\begin{array}{c}\text { miR-205/ZEB1, } \\
\text { ZEB2 }\end{array}$ & $\begin{array}{c}\text { TGF- } \beta \text {-induced } \\
\text { EMT }\end{array}$ & $\begin{array}{c}\text { MCF-7, } \\
\text { MDA-MB-231 }\end{array}$ & [202] \\
\hline HOTAIR & Tamoxifen & $\mathrm{u}$ & + & ER signaling & Cell proliferation & MCF-7 & [205] \\
\hline BCAR4 & Tamoxifen & $\mathrm{u}$ & + & $\begin{array}{l}\text { ERBB2 and } \\
\text { ERBB3 } \\
\text { signaling }\end{array}$ & $\begin{array}{l}\text { Cell survival and } \\
\text { proliferation }\end{array}$ & ZR-75-1 & [207] \\
\hline CCAT2 & Tamoxifen & $\mathrm{u}$ & + & $\begin{array}{l}\text { Wnt } / \beta \text {-catenin } \\
\text { pathway }\end{array}$ & $\begin{array}{l}\text { Cell survival and } \\
\text { viability }\end{array}$ & MCF-7, T47D & {$[209,211]$} \\
\hline \multirow{3}{*}{ UCA1 } & Tamoxifen & $\mathrm{u}$ & + & EZH2/p21 & $\begin{array}{l}\text { Akt/mTOR } \\
\text { signaling }\end{array}$ & $\begin{array}{l}\text { MCF-7 } \\
\text { T47D }\end{array}$ & {$[213,214]$} \\
\hline & & $\mathrm{u}$ & + & $\begin{array}{l}\text { Wnt } / \beta \text {-catenin } \\
\text { pathway }\end{array}$ & $\begin{array}{c}\text { Cell survival and } \\
\text { EMT }\end{array}$ & MCF-7, T47D & [215] \\
\hline & & $\mathrm{u}$ & + & $\begin{array}{l}\text { miR-18a/HIF1 } \alpha \\
\text { axis }\end{array}$ & $\begin{array}{l}\text { Cell cycle } \\
\text { regulation }\end{array}$ & BT474 & [216] \\
\hline GAS5 & Tamoxifen & $\mathrm{d}$ & + & miR-222/PTEN & $\begin{array}{l}\mathrm{PI} 3 \mathrm{~K} / \mathrm{Akt} / \mathrm{mTOR} \\
\text { signaling }\end{array}$ & MCF-7 & [218] \\
\hline
\end{tabular}

${ }^{1}$ ERBB3-Erb-B2 Receptor Tyrosine Kinase 3; EZH2-Enhancer of Zeste 2 Polycomb Repressive Complex 2 Subunit; p21—cyclin dependent kinase inhibitor 1A; TGF- $\beta$ — transforming growth factor beta.

Among lncRNAs with tumor suppressor function is Growth arrest-specific 5 (GAS5). GAS5 was found significantly downregulated in mammary carcinomas, and its status was positively associated with advanced TNM stages, poor prognosis, and tamoxifen resistance. Experimental induction of GAS5 sensitized MCF-7/R cells to tamoxifen via its ceRNA interaction with miR-222, a negative regulator of PTEN, which resulted in PI3K/Akt signaling inhibition [218].

\subsection{IncRNAs and Resistance to Anti-HER2 Drugs}

The roles of lncRNAs in the clinical setting of anti-HER2 drug resistance are also beginning to be elucidated. Genome-wide profiling of differentially expressed lncRNAs in trastuzumab-resistant tumors and healthy tissues revealed 30 significantly deregulated lncRNAs and long noncoding RNA activated by TGF- $\beta$ (lncRNA ATB) was by far the most overexpressed. ATB has been shown to promote trastuzumab resistance and metastasis in BC through direct sequestration of miR-200c, leading to ZEB1 and Zinc finger protein 17 (ZNF217) overexpression and EMT [56]. ZNF217 supports TGF- $\beta$ signaling through TGF- $\beta 2$ and TGF- $\beta 3$ transcriptional activation; interestingly, TGF- $\beta$ signaling hyperactivation results in ZEB1 overexpression, outlining a possible autocrine ATB-centered regulatory loop that supports trastuzumab resistance and metastasis in BC [219].

Other individual studies revealed novel lncRNAs with oncogenic or tumor suppressor functions in BC drug-resistant tissues (Table 5). For instance, lncRNA-small nucleolar RNA host gene 14 (SNHG14) was shown to induce trastuzumab resistance via Bcl-2/Bax signaling modulation [220]. Similarly, Actin filament associated protein 1 antisense RNA1 (AFAP1-AS1)-enriched exosomes transferred anti-HER2 drugs resistance phenotype to the sensitive BC cells via AU-binding factor 1 (AUF1) regulation, which further enhanced ERBB2 translation [23]. Additionally, H19 was associated with the occurrence of trastuzumab resistance, as its experimental suppression resulted in increased therapeutic efficiency; however, the mechanisms exploited by H19 in BC targeted-therapy resistance remain to be further investigated [221]. Moreover, UCA1 acts as an oncogene in HER2-positive BC cells and sequestrates miR-18a leading to Yes-associated protein 1 (YAP1) overexpression and trastuzumab resistance [222]. Similarly, terminal differentiation-induced non-coding RNA (TINCR), present in elevated levels in the BC cells cytoplasm, may act as a sponge for miR-125b, upregulating HER-2 and Snail to induce resistance to the same antineoplastic agent in BC [223]. Increased expression of HOTAIR was shown to drive trastuzumab refractoriness in HER-2 positive BC and HOTAIR knockdown resulted in trastuzumab sensitization, and TGF- $\beta$, Snail, Vimentin, p-AKT, p-APK, and CyclinD1 suppression, respectively, E-cadherin, PTEN and P27 overexpression [224]. 
Table 5. IncRNAs in anti-HER2 drug resistance ${ }^{1}$; (u) upregulated; (d) downregulated; (+) increase; $(-)$ reduction.

\begin{tabular}{|c|c|c|c|c|c|c|c|}
\hline ncRNA(s) & Drug & Status & $\begin{array}{c}\text { Impact on Drug } \\
\text { Resistance }\end{array}$ & Target(s) & Mechanism(s) & $\begin{array}{c}\text { Experimental } \\
\text { System }\end{array}$ & References \\
\hline AFAP-AS1 & Trastuzumab & $\mathrm{u}$ & + & AUF1/ERBB2 & Cell survival & SKBR3, BT474 & [23] \\
\hline АТВ & Trastuzumab & $\mathrm{u}$ & + & $\begin{array}{c}\text { miR-200c/ZEB1, } \\
\text { ZNF-217 }\end{array}$ & EMT & $\begin{array}{c}\text { SKBR3, BC } \\
\text { patient tissues }\end{array}$ & [56] \\
\hline SNHG14 & Trastuzumab & $\mathrm{u}$ & + & $\mathrm{Bcl} / \mathrm{Bax}$ & Apoptosis & SKBR3, BT474 & [220] \\
\hline H19 & Trastuzumab & $\mathrm{u}$ & + & NA & NA & $\mathrm{BC}$ patients & [221] \\
\hline UCA1 & Trastuzumab & $\mathrm{u}$ & + & miR-18a/YAP1 & Cell viability & SKBR3 & [222] \\
\hline TINCR & Trastuzumab & $\mathrm{u}$ & + & $\begin{array}{l}\text { miR-125b/HER2, } \\
\text { Snail }\end{array}$ & EMT & SKBR3, BT474 & [223] \\
\hline HOTAIR & Trastuzumab & $\mathrm{u}$ & + & $\begin{array}{l}\text { TGF- } \beta \text {, Snail, } \\
\text { Vimentin, } \\
\text { p-AKT, } \\
\text { CyclinD1, } \\
\text { E-cadherin, } \\
\text { PTEN, P27 }\end{array}$ & $\begin{array}{c}\text { Cell cycle and } \\
\text { proliferation, EMT }\end{array}$ & SKBR3 & [224] \\
\hline GAS5 & $\begin{array}{l}\text { Trastuzumab, } \\
\text { lapatinib }\end{array}$ & $\mathrm{u}$ & - & miR-21/PTEN & $\begin{array}{l}\text { AKT/mTOR } \\
\text { modulation }\end{array}$ & SKBR3 & [225] \\
\hline
\end{tabular}

${ }^{1}$ AUF1-AU-rich element RNA-binding factor 1; YAP1—Yes Associated Protein 1 ; TGF- $\beta$ 一transforming growth factor beta.

GAS5 is, in contrast, an essential sensitizer to anti-HER2 drug resistance in BC. GAS5 was found considerably downregulated in lapatinib resistant HER2-positive BC cells and tissues and was correlated with histological grading and advanced stage. Mechanically, GAS5 sponges miR-21 and increases the expression level of its target gene PTEN. In the same study, it was demonstrated that mTOR signaling activation might be responsible for GAS silencing and the occurrence of drug resistance in HER2-positive BC [225].

\section{3. $\operatorname{lncRNAs}$ and $B C$ Chemoresistance}

IncRNAs have been identified to modulate multiple chemoresistance mechanisms in BC, bringing alluring perspectives regarding their use as diagnostic and prognostic tools in the clinical management of mammary carcinomas.

Several lncRNAs have been documented to act on components of apoptotic pathways to modulate chemoresistance in BC (Table 6). For instance, IncRNA P21-associated ncRNA DNA damage-activated (PANDA) was shown to promote doxorubicin resistance by binding it to the Nuclear Transcription Factor Y Subunit Alpha (NF-YA). Subsequently, the reduction of the levels of the pro-apoptotic genes Apoptotic protease activating factor 1 (APAF-1), Bumped kinase inhibitor (BKI), Fas Cell Surface Death Receptor (FAS), and Leucine-rich repeats and death domain-containing (LRDD) occurs [226]. IncRNA Adriamycin Resistance Associated (ARA) was also associated with the development of chemoresistance in BC. It was further shown that lncRNA ARA knockdown sensitized BC cells to anthracyclines, triggering apoptosis, G2/M arrest, and impaired cancer cell motility. Notably, lncRNA ARA silencing led to the upregulation of the pro-apoptotic protein Bcl-2 Associated X (BAX) and downregulation of the antiapoptotic B-cell lymphoma extra-large (Bcl-xL) protein, highlighting their roles as valuable target genes. Pathway analysis further elucidated that besides apoptosis, lncRNA ARA-target genes are enriched in multiple signaling pathways, such as MAPK and Peroxisome proliferator-activated receptor (PPAR) signaling, focal adhesion, purine, and pyrimidine metabolism, and cell cycle progression [227]. Likewise, the recently annotated LncRNA NONHSAT141924 was associated with therapeutic failure in BC. IncRNA NONHSAT141924 depletion restored paclitaxel sensitivity via modulating the phospho-cAMP-response element-binding protein (p-CREB)/Bcl-2 axis in BC [228]. Another study recognized the effect of upregulated lncRNA H19 in exacerbating BC chemoresistance. The experimental induction of lncRNA H19 was shown to attenuate paclitaxel-induced apoptosis in 
ER $\alpha$-positive BC via epigenetic regulation of the key pro-apoptotic genes BCL2 Interacting Killer (BIK) and Phorbol-12-myristate-13-acetate-induced protein 1 (NOXA) in an EZH2-dependent manner [229].

Other lncRNAs have been documented to exert their regulatory functions on crucial players of DNA damage response and cell survival pathways, significantly impacting the therapeutic response in BC. For example, lncRNA BMP/OP-Responsive Gene (BORG) is an oncogenic lncRNA triggered in TNBC cells by the cellular stress exerted by chemotherapeutics. BORG expression is fueled by Nuclear factor- $\kappa \mathrm{B}(\mathrm{NF}-\mathrm{kB})$ through a novel BORG-mediated feed-forward signaling loop. It endows cells with a chemoresistant phenotype through Replication Protein A1 (RPA1) activation, an essential protein involved in DNA damage repair. Therapeutic targeting of BORG and its downstream modulators resulted in doxorubicin resensitization in TNBC [230]. Interestingly, LINC00968 was shown to boost the adriamycin's therapeutic efficiency through WNT2 downregulation and the subsequent disruption of the Wnt $2 / \beta$-catenin-associated signaling [231]. Similarly, the tumor suppressor IncRNA GAS5 was shown to target $\mathrm{Wnt} / \beta$-catenin signaling and attenuate ABCB-1-mediated adriamycin resistance via miR-221-3p/Dickkopf-related protein 2 (DKK2) pathway regulation [232].

Evidence for the mechanistic link between lncRNAs and cell cycle dysfunction comes from a considerable number of studies. IncRNA Mitosis-Associated Long Intergenic Non-Coding RNA 1 (MA-linc1), involved in cell cycle control and M-phase exit, was overexpressed in paclitaxel-resistant BC cells. Its silencing increased the number of cells in the G2/M phase and enhanced paclitaxel-induced apoptosis, highlighting the crucial role of this lncRNA in proliferative function regulation [233]. UCA1, also part of the paclitaxel resistance signature in BC, was shown to act as a molecular sponge for miR-613, leading to elevated CDK12 levels [234]. Genome-wide profiling analysis of lncRNA expression revealed that $4030 \mathrm{lncRNAs}$ and unannotated transcripts were upregulated, and 3708 were downregulated between anthracycline-resistant and sensitive MCF-7 cells. Among them, lncRNA NONHSAT02871 was found to regulate nearby CDK2 mRNA levels, thereby supporting cell cycle progression and chemoresistance in BC. Additionally, two other dysregulated lncRNAs, NONHSAT057282, and NONHSAG023333, were found to influence BC chemosusceptibility. It was further shown that these lncRNAs interacted with ELF1 and E2F1, respectively, to trans-regulate several chemoresistance-related genes such as Glutathione S-Transferase Pi 1 (GSTP1), BTG Anti-Proliferation Factor 3 (BTG3), Suppressor of Cytokine Signaling 3 (SOCS3), and breast cancer susceptibility gene (BRAC2) [235].

Other authors have highlighted the regulatory influences of lncRNAs on cancer stemness and EMT-related players. For instance, lncRNA nuclear paraspeckle assembly transcript 1 (NEAT1), highly upregulated in TNBC tissues, was shown to confer cisplatin chemoresistance via regulating CSCs biomarkers CD44, CD24, aldehyde dehydrogenase (ALDH), and SRY-related HMG-box 2 (SOX2) [22]. In addition to its involvement in DNA Damage Repair, IncRNA in non-homologous end joining (NHEJ) pathway 1 (LINP1) has been shown to act on EMT key regulators to support resistance to doxorubicin and 5-FU. The p53-regulated LINP1 has been associated with lower overall survival and a poor prognosis. Its siRNA-mediated knockdown has been associated with the conversion of BC cells to an epithelial state and the inhibition of chemoresistance [236]. Similarly, ZEB 1 antisense RNA 1 (ZEB1-AS1) depletion was proved to restore cisplatin sensitivity in BC by increasing miR-129-5p levels and negatively regulating its target gene ZEB1 [237]. Moreover, lncRNA ROR has been shown to render $\mathrm{BC}$ cells refractory to conventional therapies via $\mathrm{N}$-cadherin and vimentin upregulation and E-cadherin downregulation in BC [238]. Additionally, it was observed that lncRNA ROR links EMT with $\mathrm{ABC}$ transporters in $\mathrm{BC}$ chemoresistance. This lncRNA modulates ABCB1 mRNA and protein levels in MDR-BC cells, and its inhibition resulted in decreased ABCB1-drug effuxing activity and enhanced chemosensitivity [239].

Several recent studies have highlighted various lncRNA signatures that may be used as biomarkers in monitoring the therapeutic response in BC. One such study was led by Wang, who identified 36 dysregulated lncRNAs that may serve as biomarkers for the response to neoadjuvant chemotherapy in $\mathrm{BC}$, but further research regarding their biological functions has not yet been conducted [240]. Another 
study, led by Zeng et al., 2019, highlighted that elevated levels of lncRNAs AK291479 and BC032585 and low levels of lncRNA U79293 are indicators of pCR after neoadjuvant chemotherapy. Weighted gene co-expression network analysis and functional gene annotation revealed that these three molecules are involved in cell cycle regulation. To investigate the regulatory functions of BC032585 in this context, BC032585 was silenced, and this resulted in chemoresistance via MDR1 upregulation in BC [241]. We believe that further studies aiming at elucidating specific lncRNA expression signatures associated with various chemoresistance phenotypes will provide a more accurate picture of the magnitude of transcriptome changes induced by the chemotherapeutic stress in cancers, including BC.

Table 6. Several lncRNAs involved in regulating BC drug resistance to anthracyclines, taxanes, platinum compounds, and antimetabolites ${ }^{1}$; (u) upregulated; (d) downregulated; (+) increase; (-) reduction.

\begin{tabular}{|c|c|c|c|c|c|c|c|}
\hline ncRNA(s) & Drug & Status & $\begin{array}{l}\text { Impact on Drug } \\
\text { Resistance }\end{array}$ & Target (s) & Mechanism(s) & $\begin{array}{l}\text { Experimental } \\
\text { System }\end{array}$ & References \\
\hline NEAT & $\begin{array}{l}\text { Cisplatin } \\
\text { taxol }\end{array}$ & $\mathrm{u}$ & + & $\begin{array}{l}\text { CD44, CD24, } \\
\text { SOX2 }\end{array}$ & Cellular stemness & MDA-MB-231 & [22] \\
\hline \multirow[t]{2}{*}{ H19 } & Antracyclines & $\mathrm{u}$ & + & $\begin{array}{l}\text { CUL4A-ABCB1/ } \\
\text { MDR1 }\end{array}$ & Drug efflux & MCF-7 & [58] \\
\hline & Paclitaxel & $\mathrm{u}$ & + & BIK, NOXA & Apoptosis & MCF-7, ZR-75-1 & [229] \\
\hline PANDA & Doxorubicin & $\mathrm{u}$ & + & $\begin{array}{l}\text { NF-YA/APAF-1, } \\
\text { BKI, FAS and } \\
\text { LRDD }\end{array}$ & Apoptosis & $\begin{array}{l}\text { Primary breast } \\
\text { tumors }\end{array}$ & [226] \\
\hline ARA & Doxorubicin & $\mathrm{u}$ & + & NA & $\begin{array}{l}\text { MAPK and PPAR } \\
\text { signaling, } \\
\text { metabolic } \\
\text { signaling } \\
\text { pathways, cell } \\
\text { cycle and focal } \\
\text { adhesion }\end{array}$ & MCF-7 & [227] \\
\hline NONHSAT141924 & Paclitaxel & $\mathrm{u}$ & + & p-CREB/Bcl2 & Apoptosis & MCF-7 & [228] \\
\hline BORG & Doxorubicin & $\mathrm{u}$ & + & RPA-1 & $\begin{array}{l}\text { Cell survival and } \\
\text { DNA damage } \\
\text { repair }\end{array}$ & SKBR3, BT474 & [230] \\
\hline LINC00968 & Adriamycin & $\mathrm{u}$ & - & Wnt2 & $\begin{array}{c}\text { Wnt } / \beta \text {-catenin } \\
\text { survival pathway }\end{array}$ & MCF-7, KPL-4 & [231] \\
\hline GAS5 & Adriamycin & d & + & $\begin{array}{c}\text { miR-221/DKK2 } \\
\text { and } \\
\text { Wnt } / \beta \text {-catenin } \\
\text { survival }\end{array}$ & Drug efflux & MCF-7 & [232] \\
\hline MA-linc1 & Paclitaxel & $\mathrm{u}$ & + & Pur $\alpha$ & $\begin{array}{l}\text { Cell cycle } \\
\text { regulation }\end{array}$ & $\mathrm{U} 2 \mathrm{OS}$ & [233] \\
\hline UCA1 & Paclitaxel & $\mathrm{u}$ & + & miR-613/CDK12 & $\begin{array}{l}\text { Cell viability and } \\
\text { apoptosis }\end{array}$ & MCF-7 & [234] \\
\hline $\begin{array}{l}\text { NONHSAT028712 } \\
\text { NONHSAT057282 } \\
\text { NONHSAG023333 }\end{array}$ & Doxorubicin & $\begin{array}{l}\mathrm{u} \\
\mathrm{u} \\
\mathrm{u}\end{array}$ & $\begin{array}{l}+ \\
+ \\
-\end{array}$ & $\begin{array}{c}\text { CDK2 } \\
\text { ELF1, E2F1, } \\
\text { SOCS3, } \\
\text { BRAC2 }\end{array}$ & $\begin{array}{l}\text { Cell cycle } \\
\text { regulation and } \\
\text { survival }\end{array}$ & MCF-7 & [235] \\
\hline LINP1 & $\begin{array}{c}\text { 5-FU } \\
\text { doxorubicin }\end{array}$ & $\begin{array}{l}\mathrm{u} \\
\mathrm{u}\end{array}$ & $\begin{array}{l}+ \\
+\end{array}$ & $\begin{array}{l}\text { N/E-cadherin, } \\
\text { vimentin } \\
\text { Ku80 }\end{array}$ & $\begin{array}{c}\text { EMT } \\
\text { DNA Damage } \\
\text { Repair }\end{array}$ & MDA-MB-231 & $\begin{array}{l}{[236]} \\
{[242]}\end{array}$ \\
\hline ZEB1-AS1 & Cisplatin & $\mathrm{u}$ & + & miR-129-5p/ZEB1 & EMT & MCF-7 & [237] \\
\hline \multirow[t]{2}{*}{ ROR } & $\begin{array}{c}\text { 5-FU } \\
\text { paclitaxel }\end{array}$ & $\mathrm{u}$ & + & $\begin{array}{l}\text { N/E-cadherin, } \\
\text { vimentin }\end{array}$ & EMT & $\begin{array}{l}\text { BC tissues and } \\
\text { lines }\end{array}$ & [238] \\
\hline & MDR & $\mathrm{u}$ & + & ABCB1 & Drug efflux & $\begin{array}{l}\text { MDA-MB-231, } \\
\text { Sum159PT }\end{array}$ & [239] \\
\hline Linc00152 & Doxorubicin & $\mathrm{u}$ & + & $\begin{array}{l}\text { N-cadherin, } \\
\text { E-cadherin, } \\
\text { vimentin }\end{array}$ & EMT & $\begin{array}{l}\text { MDA-MB-231, } \\
\text { MCF-7 }\end{array}$ & [243] \\
\hline
\end{tabular}


Table 6. Cont.

\begin{tabular}{|c|c|c|c|c|c|c|c|}
\hline ncRNA(s) & Drug & Status & $\begin{array}{c}\text { Impact on Drug } \\
\text { Resistance }\end{array}$ & Target (s) & Mechanism(s) & $\begin{array}{l}\text { Experimental } \\
\text { System }\end{array}$ & References \\
\hline AX747207 & Doxorubicin & d & + & RUNX3 & $\begin{array}{l}\text { PI3K/Akt, Hippo } \\
\text { and ErbB } \\
\text { oncogenic } \\
\text { pathways }\end{array}$ & MCF-7 & [244] \\
\hline PRLB & 5-FU & $\mathrm{u}$ & + & $\mathrm{miR}-4766-5 \mathrm{p} / \mathrm{s}$ & $\begin{array}{l}\text { Tumor growth } \\
\text { and metastasis }\end{array}$ & MDA-MB-231/468 & [245] \\
\hline \multicolumn{8}{|c|}{$\begin{array}{l}\text { 1 BIK-BCL2 Interacting Killer; NOXA-phorbol-12-myristate-13-acetate-induced protein 1; CUL4A-Cullin-4A; } \\
\text { MDR1-multi-drug resistance-1/P-glycoprotein; NA-not available; CDK2-Cyclin Dependent Kinase 2; } \\
\text { ELF1-E74-like factor 1; E2F1-E2F Transcription Factor 1; SOCS3-Suppressor of Cytokine Signaling 3; } \\
\text { RPA-1-Replication Protein A1; RUNX3-RUNX Family Transcription Factor 3; SIRT1-Sirtuin 1; NF-YA-Nuclear } \\
\text { Transcription Factor Y Subunit Alpha; APAF-1—apoptotic protease activating factor-1; BKI-bumped kinase inhibitor; } \\
\text { FAS-Fas Cell Surface Death Receptor; LRDD-Leucine Rich Repeats And Death Domain Containing Protein; } \\
\text { DKK2-Dickkopf WNT Signaling Pathway Inhibitor 2; Pur } \alpha \text { - purine-rich binding protein- } \alpha \text {; ZEB1-Zinc Finger } \\
\text { E-Box Binding Homeobox 1; Wnt2-Wnt Family Member 2; PPAR-peroxisome proliferator-activated receptor. }\end{array}$} \\
\hline
\end{tabular}

\section{5. ncRNAs and their Predictive Value in BC}

Although the clinicopathological factors, such as tumor size, tumor grade, intrinsic subtype, and lymph node status are relevant to $\mathrm{BC}$ prognosis, they are unsatisfactory for predicting treatment outcomes in BC patients [246]. This has prompted the search for more dynamic biomarkers, such as miRNAs and lncRNAs, that can assist in predicting survival, metastasis, and patients' prognosis following therapy. Their variable expression may distinguish between responsive and non-responsive groups, allowing the detection of resistance at an early stage [247].

Several studies have focused on ncRNAs involved in responsiveness to endocrine therapies. For example, Zhong and colleagues found that high levels of miR-30c independently predicted the clinical benefit of tamoxifen in ER-positive BC patients [248]. Conversely, Uhr et al. found that miR-7 is associated with poor PFS and OS in TAM-treated BC patients [249]. Other studies analyzed ncRNAs able to predict responsiveness to other therapies. The elevated miR-21 expression has been correlated with recurrence and poor OS in HER2-enriched-trastuzumab-treated patients [84]. High circulating levels of miR-375 and low levels of miR-122 were associated with an improved OS for stage II-III HER2-positive BC patients who underwent chemotherapy [250]. Some other studies suggested that miR-221, miR-222, and miR-155 are some of the most important indicators of poor prognosis in BC patients receiving chemotherapy; their increased expression is associated with lymph node metastasis, and tumor grade, which results in disease recurrence and patient death [251,252]. Some other ncRNAs with predictive value in BC are summarized in Table 7.

The majority of studies conducted so far assessed the predictive ability of a single ncRNA, which may be unsatisfactory for predicting complex biological events such as resistance or metastasis [253]. However, the current research has shifted towards the identification of ncRNA signatures incorporating multiple molecules that may be more relevant for the course of the disease. For instance, Wang et al. identified an 11-lncRNAs-based signature that could predict longer RSF in ER-positive BC patients treated with tamoxifen [204]. On the other hand, Tang et al. developed a lncRNA signature indicative of recurrence in ER-positive BC patients receiving endocrine therapy [254]. Jiang and colleagues also discovered an mRNA-lncRNA signature able to subdivide TNBC patients into groups with high or low risk of relapse. Additionally, the signature could predict response to taxane-based chemotherapy in these patients [255]. Although research concerning ncRNAs as predictive biomarkers for BC is still in its infancy, someday, they will have their place in the precision medicine initiative. 
Table 7. Compendium of ncRNAs associated with the clinical outcome in BC ${ }^{1} ;(\uparrow)$-increased; $(\downarrow)$-decreased.

\begin{tabular}{|c|c|c|c|c|}
\hline Clinical Outcome & ncRNA(s) & Biological Samples & Association & Reference(s) \\
\hline \multirow{6}{*}{ Survival } & $\uparrow \mathrm{miR}-4653-3 p$ & FFPE BC tissues & $\begin{array}{l}\text { Increased DSF in ER-positive } B C \text { patients } \\
\text { receiving TAM adjuvant therapy }\end{array}$ & [256] \\
\hline & $\begin{aligned} \uparrow \mathrm{miR}-30 \mathrm{c}-5 \mathrm{p}, & \uparrow \mathrm{miR}-\uparrow 30 \mathrm{~b}-5 \mathrm{p}, \downarrow \mathrm{miR}-182-5 \mathrm{p}, \\
& \uparrow \mathrm{miR}-200 \mathrm{~b}-3 \mathrm{p}\end{aligned}$ & Fresh frozen $B C$ tissues & $\begin{array}{l}\text { Improved ERFS in endocrine therapy-treated } \\
\text { BC patients }\end{array}$ & [257] \\
\hline & $\uparrow \mathrm{miR}-204$ & FFPE tissues & $\begin{array}{l}\text { Improved DSF and OS in patients treated with } \\
\text { chemotherapy; inverse correlation with TNM } \\
\text { stage and metastasis }\end{array}$ & [258] \\
\hline & $\uparrow \mathrm{miR}-375$ & BC tissues and serum & $\begin{array}{l}\text { Improved OS for stage II-III HER2-positive BC } \\
\text { patients who underwent chemotherapy }\end{array}$ & [250] \\
\hline & $\uparrow \mathrm{miR}-30 \mathrm{c}$ & $\mathrm{BC}$ tissues & $\begin{array}{c}\text { Response to TAM and longer PFS in } \\
\text { ER-positive BC patients }\end{array}$ & [248] \\
\hline & $\begin{array}{c}\uparrow P I N K 1 . A S, \uparrow K L F 3 . A S 1, \uparrow L I N C 00339, \\
\uparrow L I N C 00472, \uparrow R P 11.35121 .11, \\
\uparrow P K D 1 P 6 . N P I P P 1, \uparrow P D C D 4 . A S 1, \\
\uparrow R P 11.69 E 11.4, \downarrow R P 11.259 N 19.1, \\
\downarrow K B .1460 A 1.5, \downarrow P P 14571\end{array}$ & $\mathrm{BC}$ tissues & $\begin{array}{l}\text { Longer RSF in ER positive BC patients treated } \\
\text { with tamoxifen }\end{array}$ & [204] \\
\hline \multirow{6}{*}{ Relapse } & $\uparrow \mathrm{miR}-7$ & $\begin{array}{l}\text { BC cell lines and fresh frozen } \\
\text { tissues }\end{array}$ & $\begin{array}{l}\text { Poor PFS and post-relapse OS in TAM-treated } \\
\text { BC patients }\end{array}$ & [249] \\
\hline & $\uparrow \mathrm{miR}-210$ & $\begin{array}{l}\text { BC cell tissues; BC cells an } \\
\text { TEMs in coculture }\end{array}$ & $\begin{array}{l}\text { Reduced DSF and OS in tamoxifen treated } \\
\text { ER-positive BC patients }\end{array}$ & [259-261] \\
\hline & $\uparrow \mathrm{miR}-21$ & Frozen tissues & $\begin{array}{l}\text { Poor patient outcome in trastuzumab-treated } \\
\text { patients }\end{array}$ & [84] \\
\hline & $\uparrow \mathrm{miR}-454$ & FFPE BC tissues & $\begin{array}{l}\text { Worse DFS in anthracycline-treated TNBC } \\
\text { patients }\end{array}$ & [262] \\
\hline & $\uparrow \mathrm{miR}-221 / 222$ & $\begin{array}{l}\text { FFPE and frozen BC tissues, cell } \\
\text { lines }\end{array}$ & $\begin{array}{l}\text { Poor prognosis related to lymph node } \\
\text { metastasis in BC patients undergoing } \\
\text { chemotherapy }\end{array}$ & {$[251,263]$} \\
\hline & $\uparrow \mathrm{miR}-95-3 p$ & FFPE BC tissues & $\begin{array}{l}\text { Decreased OS and RFS in patients treated with } \\
\text { anthracycline-based chemotherapy }\end{array}$ & [264] \\
\hline
\end{tabular}


Table 7. Cont

\begin{tabular}{|c|c|c|c|c|}
\hline Clinical Outcome & ncRNA(s) & Biological Samples & Association & Reference(s) \\
\hline & $\begin{array}{c}\uparrow \mathrm{miR}-222, \uparrow \mathrm{miR}-29 \mathrm{a}, \uparrow \mathrm{miR}-140, \uparrow \mathrm{miR}-574, \\
\uparrow \mathrm{miR}-6780 \mathrm{~b}, \uparrow \mathrm{miR}-7107, \uparrow \mathrm{miR}-744\end{array}$ & FFPE BC tissues & $\begin{array}{l}\text { Associated with decreased PFS and OS in } \\
\text { chemotherapy-treated BC patients }\end{array}$ & [263] \\
\hline & $\uparrow \mathrm{miR}-125, \uparrow \mathrm{miR}-21$ & Serum & $\begin{array}{c}\text { Decreased DSF in patients receiving } \\
\text { neoadjuvant chemotherapy }\end{array}$ & [265] \\
\hline & $\uparrow \mathrm{miR}-122$ & $\mathrm{BC}$ tissues and serum & $\begin{array}{l}\text { Predicts metastatic recurrence in stage II-III } \\
\text { HER2-positive BC patients who underwent } \\
\text { chemotherapy }\end{array}$ & [250] \\
\hline & $\uparrow \mathrm{miR}-155$ & $\mathrm{BC}$ tissues & $\begin{array}{l}\text { Associated with tumor grade and lymph node } \\
\text { metastasis in paclitaxel-resistant BC patients }\end{array}$ & [252] \\
\hline & $\uparrow$ HOTAIR & $\mathrm{BC}$ tissues & Metastatic disease and poor OS & [20] \\
\hline & $\uparrow \mathrm{HIF} 1 \mathrm{~A}-\mathrm{AS} 2, \uparrow \mathrm{AK} 124454$ & $\mathrm{BC}$ tissues & $\begin{array}{l}\text { Poor outcome in paclitaxel-resistant TNBC } \\
\text { patients }\end{array}$ & [255] \\
\hline & $\begin{array}{c}\uparrow F A M 224 \mathrm{~A}, \uparrow \mathrm{LINC00987,} \uparrow \mathrm{MCM} 3 \mathrm{AP}-\mathrm{AS} 1, \\
\uparrow \mathrm{RP} 11-351 \mathrm{I} 21.11, \uparrow S N H G 17, \downarrow \text { CTA-228A9.4, } \\
\downarrow \text { EGOT, } \downarrow \text { HAND2-AS1 }\end{array}$ & BC tissues & $\begin{array}{l}\text { Poor OS in ER-positive patients receiving } \\
\text { endocrine therapy }\end{array}$ & [254] \\
\hline
\end{tabular}
1 Endocrine resistance-free survival (ERFS); OS—overall survival; DFS—disease-free survival; PFS—progression-free survival; FFPE—formalin-fixed paraffin-embedded;
TNBC—-triple-negative breast cancer. 


\section{Discussion}

Breast cancer is the most commonly diagnosed malignancy in women and has become the second leading cause of cancer-related deaths among females globally. It is a heterogeneous disease with variable molecular underpinnings, leading to considerable differences in prognosis, propensity to metastasize, therapeutic responses, and long-term patient survival. Although the use of systemic therapies (targeted therapy, endocrine therapy, and chemotherapy) has greatly improved pathological complete response and overall survival, a robust body of evidence has shown that not all $\mathrm{BC}$ patients are sensitive to conventional therapies, due to the innate and/or acquired drug resistance [33]. To overcome the challenges posed by the formidable heterogeneity of $\mathrm{BC}$, at the moment, the efforts of the scientific community are oriented towards the identification of novel biomarkers with diagnostic, predictive, and prognostic power in this clinical setting. Recently, non-coding RNAs (ncRNAs), especially microRNAs (miRNAs) and long non-coding RNAs (lncRNAs) emerged as key regulators in BC drug resistance via modulating its canonical pathways at epigenetic, transcriptional, and post-transcriptional levels. Due to their increased stability in body fluids and their ubiquitous involvement in BC intracellular and intercellular signaling, ncRNAs are regarded as promising biomarkers in BC management and are expected to open new directions of research in precision medicine [35,47].

Here, we reviewed the literature on the involvement of miRNAs and lncRNAs in the mechanisms that render BC resistant to medication and identified several ncRNAs that can serve as potential biomarkers of response to systemic therapies (endocrine therapy, targeted therapies, and chemotherapy) in BC. These molecules have been shown to amplify or weaken BC drug resistance via regulating apoptosis/cell survival pathways, drug targets, epithelial-mesenchymal transition (EMT), cancer stemness, cell cycle progression, drug efflux mechanisms, as well as many other pathways (Figure 3). The use of anti-miRNAs and miRNA mimics to deplete oncogenic miRNAs and simulate endogenous tumor suppressor miRNAs, is documented to reverse BC drug resistance in different experimental systems successfully. Therefore, the administration of certain RNA-based formulations in conjunction with systemic therapies is a promising strategy for combating the burden of drug resistance in BC.

However, it is challenging to choose ncRNAs with the highest therapeutic potential among a plethora of potential candidates. Our attention, as well as that of the scientific community, is focused on the ncRNAs that regulate multiple drug resistance phenotypes in BC and other cancers. Such examples can be found in Figure 4, in the regions where different sets of drug resistance associated-ncRNAs overlap. Interestingly, besides its involvement in BC drug resistance, lncRNA UCA1 was shown to promote chemoresistance against various agents in different cancers, such as prostate cancer (docetaxel) [266], ovarian cancer (cisplatin) [263], colorectal cancer (5-FU) [267], chronic myeloid leukemia (imatinib) [268], bladder cancer (cisplatin, gemcitabine) [269], and gastric cancer (MDR) [270]. Additionally, overexpressed miR-221 was shown to enhance cisplatin resistance in osteosarcoma via Protein phosphatase 2 (PP2A) targeting [271], but also rendered pancreatic cancer cells refractory to 5-FU through regulating the gene encoding for Retinoblastoma Protein 1 (RB1) [272]. IncRNA GAS5 was also found to enhance the therapeutic efficiency in various cancers, such as non-small cell lung cancer (NSCLC) [273], pancreatic cancer [274], and prostate cancer [275], thereby acting as a valuable tumoral suppressor. However, the enthusiasm generated by the therapeutic power of these molecules is tempered by several challenges that need to be overcome as soon as possible. These include the need for validation in the clinical setting, standardization of current methodologies for ncRNA isolation and quantification, and the investigation of the in vivo effects of artificial miRNAs and lncRNA mimics in complex interactions such as competitive endogenous RNAs (ceRNAs) [276-278]. 


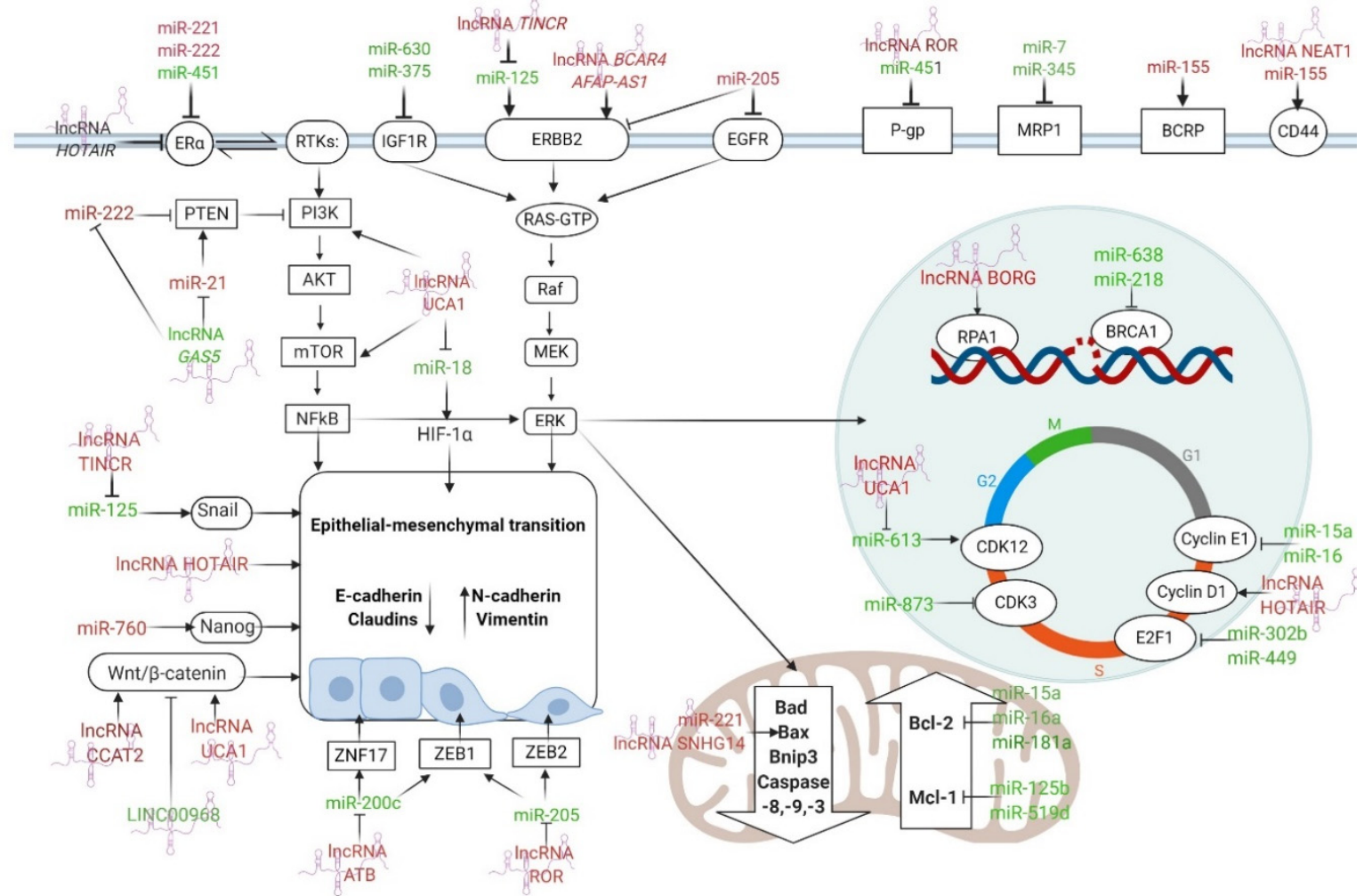

Figure 3. The most important ncRNAs that regulate ER and HER2 receptors, drug efflux, apoptosis, DDR, cell cycle arrest, EMT, and CSCs features in BC drug resistance. The arrows indicate the stimulation of the signaling pathway, while the T-bars indicate the inhibition of the signaling pathway. ncRNAs with tumor suppressor functions are stained green, while oncogenic ncRNAs are stained red. Figure created with Biorender.com.

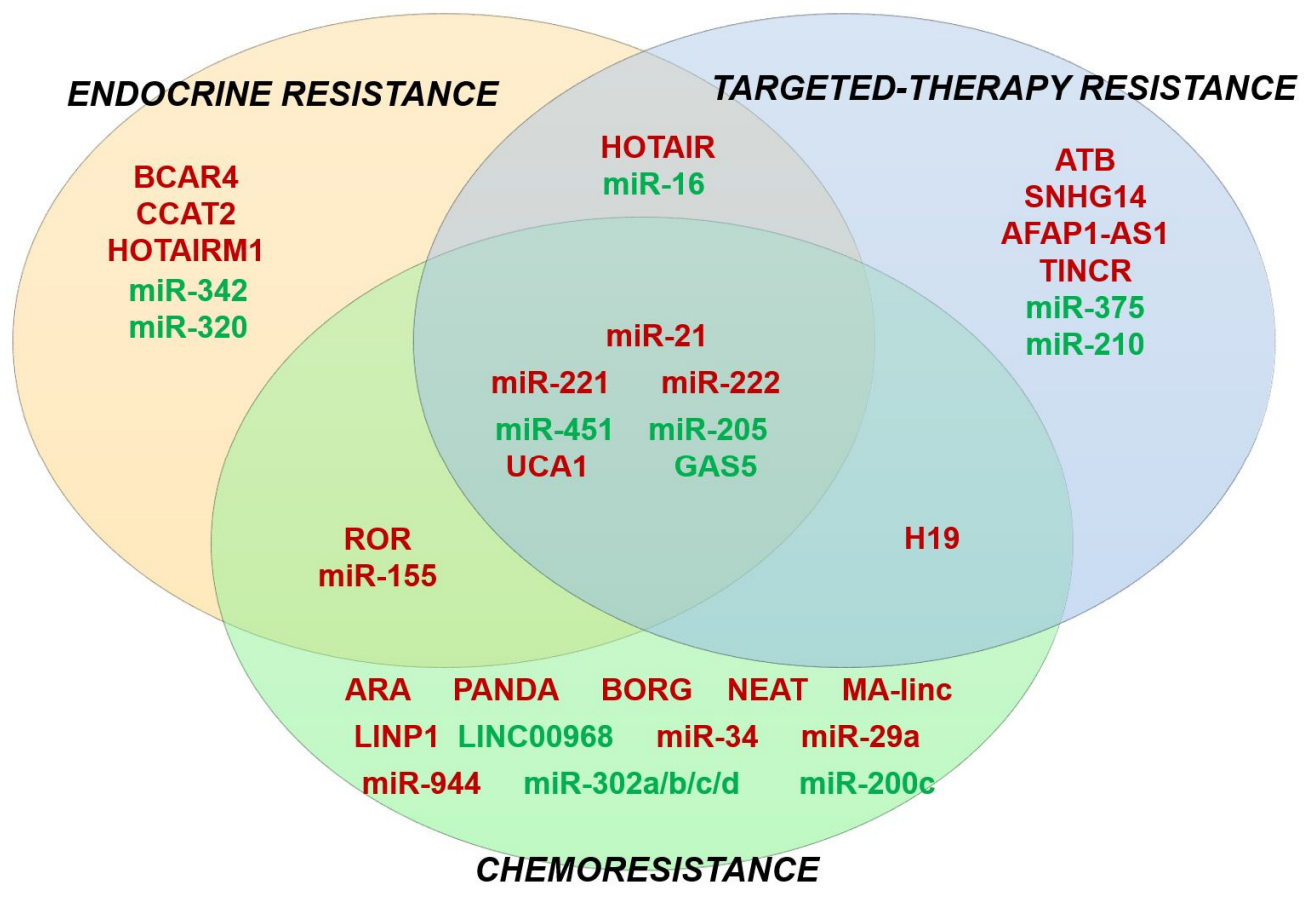

Figure 4. Venn diagram showing an overlapping role of several miRNAs and lncRNAs in multiple drug-resistant phenotypes in BC. ncRNAs with tumor suppressor functions are stained green, while oncogenic ncRNAs are stained red. 


\section{Conclusions}

Undoubtedly, BC drug resistance and ncRNAs are two hot topics of our modern times; therefore, we consider that further characterization of these ncRNAs in relationship with their genomic functions and impact on chromatin architecture is likely to provide novel biomarkers for validation in clinical cohorts, which may be ultimately for patient risk stratification and optimization of therapeutic protocols in $\mathrm{BC}$.

Author Contributions: Conceptualization, E.-G.D., S.D. and M.C.; resources, S.D., M.C.; writing-original draft preparation, E.-G.D.; writing-review and editing, S.D. and M.C.; visualization, E.-G.D. and S.D.; supervision, S.D. and M.C.; project administration, S.D. and M.C.; funding acquisition, S.D. and M.C. All authors have read and agreed to the published version of the manuscript.

Funding: This work was supported by a grant of the Romanian Ministry of Research and Innovation, CNCS-UEFISCDI, project number PN-III-P1-1.1-PD-2016-2057 (46PD/MIAMI) and by grant number PN-III-P1-1.2-PCCDI-2017-0782/REGMED, within PNCDI III. Researchers and infrastructure development were supported by CNFIS-FDI-2020-0355 grant.

Conflicts of Interest: The authors declare no conflict of interest. The funders had no role in the design of the study; in the collection, analyses, or interpretation of data; in the writing of the manuscript, or in the decision to publish the results.

\section{References}

1. Klinge, C.M. Non-Coding RNAs in Breast Cancer: Intracellular and Intercellular Communication. Non-Coding RNA 2018, 4, 40. [CrossRef] [PubMed]

2. Bray, F.; Ferlay, J.; Soerjomataram, I.; Siegel, R.L.; Torre, L.A.; Jemal, A. Global cancer statistics 2018: GLOBOCAN estimates of incidence and mortality worldwide for 36 cancers in 185 countries. CA Cancer J. Clin. 2018, 68, 394-424. [CrossRef] [PubMed]

3. Caplan, L. Delay in breast cancer: Implications for stage at diagnosis and survival. Front. Public Health 2014, 2, 87. [CrossRef]

4. Guo, H.; Treude, F.; Krämer, O.H.; Lüscher, B.; Hartkamp, J. PAR-4 overcomes chemo-resistance in breast cancer cells by antagonizing cIAP1. Sci. Rep. 2019, 9, 1-12. [CrossRef]

5. Prat, A.; Perou, C.M. Deconstructing the molecular portraits of breast cancer. Mol. Oncol. 2011, 5, 5-23. [CrossRef] [PubMed]

6. Holliday, D.L.; Speirs, V. Choosing the right cell line for breast cancer research. Breast Cancer Res. 2011, 13, 215. [CrossRef]

7. Malhotra, A.; Jain, M.; Prakash, H.; Vasquez, K.M.; Jain, A. The regulatory roles of long non-coding RNAs in the development of chemoresistance in breast cancer. Oncotarget 2017, 8, 110671-110684. [CrossRef]

8. Wang, R.; Zhu, Y.; Liu, X.; Liao, X.; He, J.; Niu, L. The Clinicopathological features and survival outcomes of patients with different metastatic sites in stage IV breast cancer. BMC Cancer 2019, 19, 1091. [CrossRef]

9. Survival Rates for Breast Cancer. Available online: https://www.cancer.org/cancer/breast-cancer/ understanding-a-breast-cancer-diagnosis/breast-cancer-survival-rates.html (accessed on 27 July 2020).

10. Gonzalez-Angulo, A.M.; Morales-Vasquez, F.; Hortobagyi, G.N. Overview of resistance to systemic therapy in patients with breast cancer. Adv. Exp. Med. Biol. 2007, 608, 1-22. [CrossRef]

11. Masoud, V.; Pagès, G. Targeted therapies in breast cancer: New challenges to fight against resistance. World J. Clin. Oncol. 2017, 8, 120-134. [CrossRef]

12. Szostakowska, M.; Trębińska-Stryjewska, A.; Grzybowska, E.A.; Fabisiewicz, A. Resistance to endocrine therapy in breast cancer: Molecular mechanisms and future goals. Breast Cancer Res. Treat. 2019, 173, 489-497. [CrossRef] [PubMed]

13. Kyrochristos, I.D.; Ziogas, D.E.; Roukos, D.H. Dynamic genome and transcriptional network-based biomarkers and drugs: Precision in breast cancer therapy. Med. Res. Rev. 2019, 39, 1205-1227. [CrossRef] [PubMed]

14. Lander, E.S.; Linton, L.M.; Birren, B.; Nusbaum, C.; Zody, M.C.; Baldwin, J.; Devon, K.; Dewar, K.; Doyle, M.; FitzHugh, W.; et al. Initial sequencing and analysis of the human genome. Nature 2001, 409, 860-921. [CrossRef] 
15. Gomes, A.Q.; Nolasco, S.; Soares, H. Non-coding RNAs: Multi-tasking molecules in the cell. Int. J. Mol. Sci. 2013, 14, 16010-16039. [CrossRef] [PubMed]

16. Zhang, F.; Zhang, L.; Zhang, C. Long noncoding RNAs and tumorigenesis: Genetic associations, molecular mechanisms, and therapeutic strategies. Tumor Biol. 2016, 37, 163-175. [CrossRef] [PubMed]

17. Tran, A.M.; Chalbatani, G.M.; Berland, L.; Cruz De los Santos, M.; Raj, P.; Jalali, S.A.; Gharagouzloo, E.; Ivan, C.; Dragomir, M.P.; Calin, G.A. A New World of Biomarkers and Therapeutics for Female Reproductive System and Breast Cancers: Circular RNAs. Front. Cell Dev. Biol. 2020, 8, 50. [CrossRef]

18. Hansen, T.B.; Jensen, T.I.; Clausen, B.H.; Bramsen, J.B.; Finsen, B.; Damgaard, C.K.; Kjems, J. Natural RNA circles function as efficient microRNA sponges. Nature 2013, 495, 384-388. [CrossRef]

19. Memczak, S.; Jens, M.; Elefsinioti, A.; Torti, F.; Krueger, J.; Rybak, A.; Maier, L.; Mackowiak, S.D.; Gregersen, L.H.; Munschauer, M.; et al. Circular RNAs are a large class of animal RNAs with regulatory potency. Nature 2013, 495, 333-338. [CrossRef]

20. Gupta, R.A.; Shah, N.; Wang, K.C.; Kim, J.; Horlings, H.M.; Wong, D.J.; Tsai, M.-C.; Hung, T.; Argani, P.; Rinn, J.L.; et al. Long non-coding RNA HOTAIR reprograms chromatin state to promote cancer metastasis. Nature 2010, 464, 1071-1076. [CrossRef]

21. Han, M.; Wang, Y.; Liu, M.; Bi, X.; Bao, J.; Zeng, N.; Zhu, Z.; Mo, Z.; Wu, C.; Chen, X. MiR-21 regulates epithelial-mesenchymal transition phenotype and hypoxia-inducible factor- $1 \alpha$ expression in third-sphere forming breast cancer stem cell-like cells. Cancer Sci. 2012, 103, 1058-1064. [CrossRef]

22. Shin, V.Y.; Chen, J.; Cheuk, I.W.Y.; Siu, M.T.; Ho, C.W.; Wang, X.; Jin, H.; Kwong, A. Long non-coding RNA NEAT1 confers oncogenic role in triple-negative breast cancer through modulating chemoresistance and cancer stemness. Cell Death Dis. 2019, 10, 1-10. [CrossRef] [PubMed]

23. Han, M.; Gu, Y.; Lu, P.; Li, J.; Cao, H.; Li, X.; Qian, X.; Yu, C.; Yang, Y.; Yang, X.; et al. Exosome-mediated lncRNA AFAP1-AS1 promotes trastuzumab resistance through binding with AUF1 and activating ERBB2 translation. Mol. Cancer 2020, 19, 26. [CrossRef] [PubMed]

24. De Cola, A.; Volpe, S.; Budani, M.C.; Ferracin, M.; Lattanzio, R.; Turdo, A.; D'Agostino, D.; Capone, E.; Stassi, G.; Todaro, M.; et al. miR-205-5p-mediated downregulation of ErbB/HER receptors in breast cancer stem cells results in targeted therapy resistance. Cell Death Dis. 2015, 6, e1823. [CrossRef] [PubMed]

25. Zhao, L.; Wang, Y.; Jiang, L.; He, M.; Bai, X.; Yu, L.; Wei, M. MIR-302a/b/c/d cooperatively sensitizes breast cancer cells to adriamycin via suppressing P-glycoprotein(P-gp) by targeting MAP/ERK kinase kinase 1 (MEKK1). J. Exp. Clin. Cancer Res. 2016, 35, 25. [CrossRef] [PubMed]

26. Cataldo, A.; Piovan, C.; Plantamura, I.; D'Ippolito, E.; Camelliti, S.; Casalini, P.; Giussani, M.; Déas, O.; Cairo, S.; Judde, J.G.; et al. MiR-205 as predictive biomarker and adjuvant therapeutic tool in combination with trastuzumab. Oncotarget 2018, 9, 27920-27928. [CrossRef]

27. Hu, Y.; Qiu, Y.; Yagüe, E.; Ji, W.; Liu, J.; Zhang, J. MiRNA-205 targets VEGFA and FGF2 and regulates resistance to chemotherapeutics in breast cancer. Cell Death Dis. 2016, 7, e2291. [CrossRef]

28. Soni, M.; Patel, Y.; Markoutsa, E.; Jie, C.; Liu, S.; Xu, P.; Chen, H. Autophagy, Cell Viability, and Chemoresistance Are Regulated By miR-489 in Breast Cancer. Mol. Cancer Res. 2018, 16, 1348-1360. [CrossRef]

29. Cheng, S.; Huang, Y.; Lou, C.; He, Y.; Zhang, Y.; Zhang, Q. FSTL1 enhances chemoresistance and maintains stemness in breast cancer cells via integrin $\beta 3 /$ Wnt signaling under miR-137 regulation. Cancer Biol. Ther. 2019, 20, 328-337. [CrossRef]

30. O’Brien, J.; Hayder, H.; Zayed, Y.; Peng, C. Overview of MicroRNA Biogenesis, Mechanisms of Actions, and Circulation. Front. Endocrinol. 2018, 9, 402. [CrossRef]

31. Steinbichler, T.B.; Dudás, J.; Skvortsov, S.; Ganswindt, U.; Riechelmann, H.; Skvortsova, I.I. Therapy resistance mediated by exosomes. Mol. Cancer 2019, 18,1-11. [CrossRef]

32. Guzel, E.; Okyay, T.M.; Yalcinkaya, B.; Karacaoglu, S.; Gocmen, M.; Akcakuyu, M.H. Tumor suppressor and oncogenic role of long non-coding RNAs in cancer. North. Clin. Istanb. 2019, 7, 81-86. [CrossRef] [PubMed]

33. Santos, J.C.; Ribeiro, M.L.; Sarian, L.O.; Ortega, M.M.; Derchain, S.F. Exosomes-mediate microRNAs transfer in breast cancer chemoresistance regulation. Am. J. Cancer Res. 2016, 6, 2129-2139. [PubMed]

34. Ariazi, E.A.; Ariazi, J.L.; Cordera, F.; Jordan, V.C. Estrogen receptors as therapeutic targets in breast cancer. Curr. Top. Med. Chem. 2006, 6, 181-202. [CrossRef] 
35. Campos-Parra, A.D.; Mitznahuatl, G.C.; Pedroza-Torres, A.; Romo, R.V.; Reyes, F.I.P.; López-Urrutia, E.; Pérez-Plasencia, C. Micro-RNAs as Potential Predictors of Response to Breast Cancer Systemic Therapy: Future Clinical Implications. Int. J. Mol. Sci. 2017, 18, 1182. [CrossRef]

36. Ali, S.; Rasool, M.; Chaoudhry, H.; Pushparaj, P.N.; Jha, P.; Hafiz, A.; Mahfooz, M.; Abdus Sami, G.; Azhar Kamal, M.; Bashir, S.; et al. Molecular mechanisms and mode of tamoxifen resistance in breast cancer. Bioinformation 2016, 12, 135-139. [CrossRef] [PubMed]

37. Van Hellemond, I.E.G.; Geurts, S.M.E.; Tjan-Heijnen, V.C.G. Current Status of Extended Adjuvant Endocrine Therapy in Early Stage Breast Cancer. Curr. Treat. Options Oncol. 2018, 19, 26. [CrossRef] [PubMed]

38. Schwartzberg, L.S.; Wang, G.; Somer, B.G.; Blakely, L.J.; Wheeler, B.M.; Walker, M.S.; Stepanski, E.J.; Houts, A.C. Phase II trial of fulvestrant with metronomic capecitabine for postmenopausal women with hormone receptor-positive, HER2-negative metastatic breast cancer. Clin. Breast Cancer 2014, 14, 13-19. [CrossRef]

39. Pernas, S.; Tolaney, S.M.; Winer, E.P.; Goel, S. CDK4/6 inhibition in breast cancer: Current practice and future directions. Ther. Adv. Med. Oncol. 2018, 10, 1758835918786451. [CrossRef]

40. Tripathy, D.; Im, S.-A.; Colleoni, M.; Franke, F.; Bardia, A.; Harbeck, N.; Hurvitz, S.A.; Chow, L.; Sohn, J.; Lee, K.S.; et al. Ribociclib plus endocrine therapy for premenopausal women with hormone-receptor-positive, advanced breast cancer (MONALEESA-7): A randomised phase 3 trial. Lancet Oncol. 2018, 19, 904-915. [CrossRef]

41. Rugo, H.S.; Finn, R.S.; Diéras, V.; Ettl, J.; Lipatov, O.; Joy, A.A.; Harbeck, N.; Castrellon, A.; Iyer, S.; Lu, D.R.; et al. Palbociclib plus letrozole as first-line therapy in estrogen receptor-positive/human epidermal growth factor receptor 2-negative advanced breast cancer with extended follow-up. Breast Cancer Res. Treat. 2019, 174, 719-729. [CrossRef]

42. Sledge, G.W.J.; Toi, M.; Neven, P.; Sohn, J.; Inoue, K.; Pivot, X.; Burdaeva, O.; Okera, M.; Masuda, N.; Kaufman, P.A.; et al. The Effect of Abemaciclib Plus Fulvestrant on Overall Survival in Hormone Receptor-Positive, ERBB2-Negative Breast Cancer That Progressed on Endocrine Therapy-MONARCH 2: A Randomized Clinical Trial. JAMA Oncol. 2019, 6, 116-124. [CrossRef] [PubMed]

43. Pandey, K.; An, H.-J.; Kim, S.K.; Lee, S.A.; Kim, S.; Lim, S.M.; Kim, G.M.; Sohn, J.; Moon, Y.W. Molecular mechanisms of resistance to CDK4/6 inhibitors in breast cancer: A review. Int. J. Cancer 2019, 145, 1179-1188. [CrossRef] [PubMed]

44. Eggemann, H.; Ignatov, T.; Burger, E.; Kantelhardt, E.J.; Fettke, F.; Thomssen, C.; Costa, S.D.; Ignatov, A. Moderate HER2 expression as a prognostic factor in hormone receptor positive breast cancer. Endocr. Relat. Cancer 2015, 22, 725-733. [CrossRef] [PubMed]

45. Zhang, Z.; Tang, P. Genomic pathology and biomarkers in breast cancer. Crit. Rev. Oncog. 2017, 22, 411-426. [CrossRef] [PubMed]

46. Pernas, S.; Tolaney, S.M. HER2-positive breast cancer: New therapeutic frontiers and overcoming resistance. Ther. Adv. Med. Oncol. 2019, 11, 1758835919833519. [CrossRef] [PubMed]

47. Campos-Parra, A.; López-Urrutia, E.; Orozco Moreno, L.; López-Camarillo, C.; Meza-Menchaca, T.; Figueroa González, G.; Bustamante Montes, L.; Pérez-Plasencia, C. Long Non-Coding RNAs as New Master Regulators of Resistance to Systemic Treatments in Breast Cancer. Int. J. Mol. Sci. 2018, 19, 2711. [CrossRef] [PubMed]

48. Martin, H.L.; Smith, L.; Tomlinson, D.C. Multidrug-resistant breast cancer: Current perspectives. Breast Cancer 2014, 6, 1-13. [CrossRef] [PubMed]

49. Teven, C.M.; Schmid, D.B.; Sisco, M.; Ward, J.; Howard, M.A. Systemic Therapy for Early-Stage Breast Cancer: What the Plastic Surgeon Should Know. Eplasty 2017, 17, e7. [PubMed]

50. Haque, M.M.; Desai, K.V. Pathways to Endocrine Therapy Resistance in Breast Cancer. Front. Endocrinol. 2019, 10, 573. [CrossRef] [PubMed]

51. Godoy-Ortiz, A.; Sanchez-Muñoz, A.; Parrado, M.R.C.; Álvarez, M.; Ribelles, N.; Dominguez, A.R.; Alba, E. Deciphering her2 breast cancer disease: Biological and clinical implications. Front. Oncol. 2019, 9, 1124. [CrossRef] [PubMed]

52. Nedeljković, M.; Damjanović, A. Mechanisms of Chemotherapy Resistance in Triple-Negative Breast Cancer-How We Can Rise to the Challenge. Cells 2019, 8, 957. [CrossRef] [PubMed]

53. Pogribny, I.P.; Filkowski, J.N.; Tryndyak, V.P.; Golubov, A.; Shpyleva, S.I.; Kovalchuk, O. Alterations of microRNAs and their targets are associated with acquired resistance of MCF-7 breast cancer cells to cisplatin. Int. J. Cancer 2010, 127, 1785-1794. [CrossRef] [PubMed] 
54. Kastl, L.; Brown, I.; Schofield, A.C. miRNA-34a is associated with docetaxel resistance in human breast cancer cells. Breast Cancer Res. Treat. 2012, 131, 445-454. [CrossRef]

55. Wei, Y.; Lai, X.; Yu, S.; Chen, S.; Ma, Y.; Zhang, Y.; Li, H.; Zhu, X.; Yao, L.; Zhang, J. Exosomal miR-221/222 enhances tamoxifen resistance in recipient ER-positive breast cancer cells. Breast Cancer Res. Treat. 2014, 147, 423-431. [CrossRef]

56. Shi, S.-J.; Wang, L.-J.; Yu, B.; Li, Y.-H.; Jin, Y.; Bai, X.-Z. LncRNA-ATB promotes trastuzumab resistance and invasion-metastasis cascade in breast cancer. Oncotarget 2015, 6, 11652-11663. [CrossRef] [PubMed]

57. Hu, Y.; Xu, K.; Yagüe, E. miR-218 targets survivin and regulates resistance to chemotherapeutics in breast cancer. Breast Cancer Res. Treat. 2015, 151, 269-280. [CrossRef]

58. Zhu, Q.N.; Wang, G.; Guo, Y.; Peng, Y.; Zhang, R.; Deng, J.L.; Li, Z.X.; Zhu, Y.S. LncRNA H19 is a major mediator of doxorubicin chemoresistance in breast cancer cells through a cullin4A-MDR1 pathway. Oncotarget 2017, 8, 91990-92003. [CrossRef]

59. Chen, D.; Si, W.; Shen, J.; Du, C.; Lou, W.; Bao, C.; Zheng, H.; Pan, J.; Zhong, G.; Xu, L.; et al. MiR-27b-3p inhibits proliferation and potentially reverses multi-chemoresistance by targeting CBLB/GRB2 in breast cancer cells. Cell Death Dis. 2018, 9, 1-13. [CrossRef]

60. Sevignani, C.; Calin, G.A.; Siracusa, L.D.; Croce, C.M. Mammalian microRNAs: A small world for fine-tuning gene expression. Mamm. Genome 2006, 17, 189-202. [CrossRef]

61. Aisina, D.; Niyazova, R.; Atambayeva, S.; Ivashchenko, A. Prediction of clusters of miRNA binding sites in mRNA candidate genes of breast cancer subtypes. Peer] 2019, 7, e8049. [CrossRef]

62. Kazimierczyk, M.; Kasprowicz, M.K.; Kasprzyk, M.E.; Wrzesinski, J. Human Long Noncoding RNA Interactome: Detection, Characterization and Function. Int. J. Mol. Sci. 2020, 21, 1027. [CrossRef] [PubMed]

63. Zhang, F.; Wang, D. The Pattern of microRNA Binding Site Distribution. Genes 2017, 8, 296. [CrossRef] [PubMed]

64. Stavast, C.J.; Erkeland, S.J. The Non-Canonical Aspects of MicroRNAs: Many Roads to Gene Regulation. Cells 2019, 8, 1465. [CrossRef] [PubMed]

65. Treiber, T.; Treiber, N.; Meister, G. Regulation of microRNA biogenesis and its crosstalk with other cellular pathways. Nat. Rev. Mol. Cell Biol. 2019, 20, 5-20. [CrossRef]

66. Martinez, I.; Hayes, K.E.; Barr, J.A.; Harold, A.D.; Xie, M.; Bukhari, S.I.A.; Vasudevan, S.; Steitz, J.A.; DiMaio, D. An Exportin-1-dependent microRNA biogenesis pathway during human cell quiescence. Proc. Natl. Acad. Sci. USA 2017, 114, E4961-E4970. [CrossRef]

67. Patterson, D.G.; Roberts, J.T.; King, V.M.; Houserova, D.; Barnhill, E.C.; Crucello, A.; Polska, C.J.; Brantley, L.W.; Kaufman, G.C.; Nguyen, M.; et al. Human snoRNA-93 is processed into a microRNA-like RNA that promotes breast cancer cell invasion. NPJ Breast Cancer 2017, 3, 25. [CrossRef]

68. Maute, R.L.; Schneider, C.; Sumazin, P.; Holmes, A.; Califano, A.; Basso, K.; Dalla-Favera, R. tRNA-derived microRNA modulates proliferation and the DNA damage response and is down-regulated in $\mathrm{B}$ cell lymphoma. Proc. Natl. Acad. Sci. USA 2013, 110, 1404-1409. [CrossRef]

69. Guo, H.; Ingolia, N.T.; Weissman, J.S.; Bartel, D.P. Mammalian microRNAs predominantly act to decrease target mRNA levels. Nature 2010, 466, 835-840. [CrossRef]

70. Gasparini, P.; Cascione, L.; Fassan, M.; Lovat, F.; Guler, G.; Balci, S.; Irkkan, C.; Morrison, C.; Croce, C.M.; Shapiro, C.L.; et al. microRNA expression profiling identifies a four microRNA signature as a novel diagnostic and prognostic biomarker in triple negative breast cancers. Oncotarget 2014, 5, 1174-1184. [CrossRef]

71. Liang, F.; Yang, M.; Tong, N.; Fang, J.; Pan, Y.; Li, J.; Zhang, X. Identification of six key miRNAs associated with breast cancer through screening large-scale microarray data. Oncol. Lett. 2018, 16, 4159-4168. [CrossRef]

72. Cai, J.; Guan, H.; Fang, L.; Yang, Y.; Zhu, X.; Yuan, J.; Wu, J.; Li, M. MicroRNA-374a activates Wnt/ $\beta$-catenin signaling to promote breast cancer metastasis. J. Clin. Investig. 2013, 123, 566-579. [CrossRef]

73. Shen, F.; Cai, W.-S.; Feng, Z.; Li, J.-L.; Chen, J.-W.; Cao, J.; Xu, B. MiR-492 contributes to cell proliferation and cell cycle of human breast cancer cells by suppressing SOX7 expression. Tumour Biol. J. Int. Soc. Oncodev. Biol. Med. 2015, 36, 1913-1921. [CrossRef] [PubMed]

74. Santos, J.C.; Lima, N.D.S.; Sarian, L.O.; Matheu, A.; Ribeiro, M.L.; Derchain, S.F.M. Exosome-mediated breast cancer chemoresistance via miR-155 transfer. Sci. Rep. 2018, 8, 829. [CrossRef] [PubMed]

75. Calin, G.A.; Sevignani, C.; Dumitru, C.D.; Hyslop, T.; Noch, E.; Yendamuri, S.; Shimizu, M.; Rattan, S.; Bullrich, F.; Negrini, M.; et al. Human microRNA genes are frequently located at fragile sites and genomic regions involved in cancers. Proc. Natl. Acad. Sci. USA 2004, 101, 2999-3004. [CrossRef] [PubMed] 
76. Ye, P.; Fang, C.; Zeng, H.; Shi, Y.; Pan, Z.; An, N.; He, K.; Zhang, L.; Long, X. Differential microRNA expression profiles in tamoxifen-resistant human breast cancer cell lines induced by two methods. Oncol. Lett. 2018, 15, 3532-3539. [CrossRef]

77. Zhou, Q.; Zeng, H.; Ye, P.; Shi, Y.; Guo, J.; Long, X. Differential microRNA profiles between fulvestrant-resistant and tamoxifen-resistant human breast cancer cells. Anticancer Drugs 2018, 29, 539-548. [CrossRef]

78. Cittelly, D.M.; Das, P.M.; Spoelstra, N.S.; Edgerton, S.M.; Richer, J.K.; Thor, A.D.; Jones, F.E. Downregulation of miR-342 is associated with tamoxifen resistant breast tumors. Mol. Cancer 2010, 9, 317. [CrossRef]

79. Lü, M.; Ding, K.; Zhang, G.; Yin, M.; Yao, G.; Tian, H.; Lian, J.; Liu, L.; Liang, M.; Zhu, T.; et al. MicroRNA-320a sensitizes tamoxifen-resistant breast cancer cells to tamoxifen by targeting ARPP-19 and ERR $\gamma *$. Sci. Rep. 2015, 5, 1-10. [CrossRef]

80. Bergamaschi, A.; Katzenellenbogen, B.S. Tamoxifen downregulation of miR-451 increases 14-3-3乙 and promotes breast cancer cell survival and endocrine resistance. Oncogene 2012, 31, 39-47. [CrossRef]

81. Chu, J.; Zhu, Y.; Liu, Y.; Sun, L.; Lv, X.; Wu, Y.; Hu, P.; Su, F.; Gong, C.; Song, E.; et al. E2F7 overexpression leads to tamoxifen resistance in breast cancer cells by competing with E2F1 at miR-15a/16 promoter. Oncotarget 2015, 6, 31944-31957. [CrossRef]

82. Yu, X.; Li, R.; Shi, W.; Jiang, T.; Wang, Y.; Li, C.; Qu, X. Silencing of MicroRNA-21 confers the sensitivity to tamoxifen and fulvestrant by enhancing autophagic cell death through inhibition of the PI3K-AKT-mTOR pathway in breast cancer cells. Biomed. Pharmacother. 2016, 77, 37-44. [CrossRef] [PubMed]

83. Wu, Z.-H.; Tao, Z.-H.; Zhang, J.; Li, T.; Ni, C.; Xie, J.; Zhang, J.-F.; Hu, X.-C. MiRNA-21 induces epithelial to mesenchymal transition and gemcitabine resistance via the PTEN/AKT pathway in breast cancer. Tumour Biol. J. Int. Soc. Oncodev. Biol. Med. 2016, 37, 7245-7254. [CrossRef]

84. Gong, C.; Yao, Y.; Wang, Y.; Liu, B.; Wu, W.; Chen, J.; Su, F.; Yao, H.; Song, E. Up-regulation of miR-21 mediates resistance to trastuzumab therapy for breast cancer. J. Biol. Chem. 2011, 286, 19127-19137. [CrossRef] [PubMed]

85. Rao, X.; Di Leva, G.; Li, M.; Fang, F.; Devlin, C.; Hartman-Frey, C.; Burow, M.E.; Ivan, M.; Croce, C.M.; Nephew, K.P. MicroRNA-221/222 confers breast cancer fulvestrant resistance by regulating multiple signaling pathways. Oncogene 2011, 30, 1082-1097. [CrossRef]

86. Sansone, P.; Berishaj, M.; Rajasekhar, V.K.; Ceccarelli, C.; Chang, Q.; Strillacci, A.; Savini, C.; Shapiro, L.; Bowman, R.L.; Mastroleo, C.; et al. Evolution of Cancer Stem-like Cells in Endocrine-Resistant Metastatic Breast Cancers Is Mediated by Stromal Microvesicles. Cancer Res. 2017, 77, 1927-1941. [CrossRef]

87. Shen, R.; Wang, Y.; Wang, C.-X.; Yin, M.; Liu, H.-L.; Chen, J.-P.; Han, J.-Q.; Wang, W.-B. MiRNA-155 mediates TAM resistance by modulating SOCS6-STAT3 signalling pathway in breast cancer. Am. J. Transl. Res. 2015, 7, 2115-2126. [PubMed]

88. Miller, T.E.; Ghoshal, K.; Ramaswamy, B.; Roy, S.; Datta, J.; Shapiro, C.L.; Jacob, S.; Majumder, S. MicroRNA-221/222 confers tamoxifen resistance in breast cancer by targeting p27Kip1. J. Biol. Chem. 2008, 283, 29897-29903. [CrossRef] [PubMed]

89. Gao, Y.; Zhang, W.; Liu, C.; Li, G. miR-200 affects tamoxifen resistance in breast cancer cells through regulation of MYB. Sci. Rep. 2019, 9, 1-6. [CrossRef]

90. Cui, J.; Yang, Y.; Li, H.; Leng, Y.; Qian, K.; Huang, Q.; Zhang, C.; Lu, Z.; Chen, J.; Sun, T.; et al. MiR-873 regulates $\mathrm{ER} \alpha$ transcriptional activity and tamoxifen resistance via targeting CDK3 in breast cancer cells. Oncogene 2015, 34, 3895-3907. [CrossRef]

91. Ahmad, A.; Ginnebaugh, K.R.; Yin, S.; Bollig-Fischer, A.; Reddy, K.B.; Sarkar, F.H. Functional role of miR-10b in tamoxifen resistance of ER-positive breast cancer cells through down-regulation of HDAC4. BMC Cancer 2015, 15, 540. [CrossRef]

92. Chen, M.-J.; Cheng, Y.-M.; Chen, C.-C.; Chen, Y.-C.; Shen, C.-J. MiR-148a and miR-152 reduce tamoxifen resistance in ER+ breast cancer via downregulating ALCAM. Biochem. Biophys. Res. Commun. 2017, 483, 840-846. [CrossRef] [PubMed]

93. Zhu, J.; Zou, Z.; Nie, P.; Kou, X.; Wu, B.; Wang, S.; Song, Z.; He, J. Downregulation of microRNA-27b-3p enhances tamoxifen resistance in breast cancer by increasing NR5A2 and CREB1 expression. Cell Death Dis. 2016, 7, e2454. [CrossRef] [PubMed]

94. Li, X.; Wu, Y.; Liu, A.; Tang, X. MiR-27b is epigenetically downregulated in tamoxifen resistant breast cancer cells due to promoter methylation and regulates tamoxifen sensitivity by targeting HMGB3. Biochem. Biophys. Res. Commun. 2016, 477, 768-773. [CrossRef] [PubMed] 
95. Yu, X.; Luo, A.; Liu, Y.; Wang, S.; Li, Y.; Shi, W.; Liu, Z.; Qu, X. MiR-214 increases the sensitivity of breast cancer cells to tamoxifen and fulvestrant through inhibition of autophagy. Mol. Cancer 2015, 14, 208. [CrossRef] [PubMed]

96. Yang, F.; Fu, Z.; Yang, M.; Sun, C.; Li, Y.; Chu, J.; Zhang, Y.; Li, W.; Huang, X.; Li, J.; et al. Expression pattern of microRNAs related with response to trastuzumab in breast cancer. J. Cell. Physiol. 2019, 234, 16102-16113. [CrossRef]

97. Li, H.; Liu, J.; Chen, J.; Wang, H.; Yang, L.; Chen, F.; Fan, S.; Wang, J.; Shao, B.; Yin, D.; et al. A serum microRNA signature predicts trastuzumab benefit in HER2-positive metastatic breast cancer patients. Nat. Commun. 2018, 9. [CrossRef]

98. Di Cosimo, S.; Appierto, V.; Pizzamiglio, S.; Silvestri, M.; Baselga, J.; Piccart, M.; Huober, J.; Izquierdo, M.; de la Pena, L.; Hilbers, F.S.; et al. Early Modulation of Circulating MicroRNAs Levels in HER2-Positive Breast Cancer Patients Treated with Trastuzumab-Based Neoadjuvant Therapy. Int. J. Mol. Sci. 2020, 21, 1386. [CrossRef]

99. Ye, X.-M.; Zhu, H.-Y.; Bai, W.-D.; Wang, T.; Wang, L.; Chen, Y.; Yang, A.-G.; Jia, L.-T. Epigenetic silencing of miR-375 induces trastuzumab resistance in HER2-positive breast cancer by targeting IGF1R. BMC Cancer 2014, 14, 134. [CrossRef]

100. Corcoran, C.; Rani, S.; Breslin, S.; Gogarty, M.; Ghobrial, I.M.; Crown, J.; O’Driscoll, L. MiR-630 targets IGF1R to regulate response to HER-targeting drugs and overall cancer cell progression in HER2 over-expressing breast cancer. Mol. Cancer 2014, 13, 71. [CrossRef]

101. Crosby, M.E.; Kulshreshtha, R.; Ivan, M.; Glazer, P.M. MicroRNA regulation of DNA repair gene expression in hypoxic stress. Cancer Res. 2009, 69, 1221-1229. [CrossRef]

102. Jung, E.-J.; Santarpia, L.; Kim, J.; Esteva, F.J.; Moretti, E.; Buzdar, A.U.; Di Leo, A.; Le, X.-F.; Bast, R.C.J.; Park, S.-T.; et al. Plasma microRNA 210 levels correlate with sensitivity to trastuzumab and tumor presence in breast cancer patients. Cancer 2012, 118, 2603-2614. [CrossRef] [PubMed]

103. De Mattos-Arruda, L.; Bottai, G.; Nuciforo, P.G.; Di Tommaso, L.; Giovannetti, E.; Peg, V.; Losurdo, A.; Pérez-Garcia, J.; Masci, G.; Corsi, F.; et al. MicroRNA-21 links epithelial-to-mesenchymal transition and inflammatory signals to confer resistance to neoadjuvant trastuzumab and chemotherapy in HER2-positive breast cancer patients. Oncotarget 2015, 6, 37269-37280. [CrossRef] [PubMed]

104. Ye, X.; Bai, W.; Zhu, H.; Zhang, X.; Chen, Y.; Wang, L.; Yang, A.; Zhao, J.; Jia, L. MiR-221 promotes trastuzumab-resistance and metastasis in HER2-positive breast cancers by targeting PTEN. BMB Rep. 2014, 47, 268-273. [CrossRef] [PubMed]

105. Venturutti, L.; Cordo Russo, R.I.; Rivas, M.A.; Mercogliano, M.F.; Izzo, F.; Oakley, R.H.; Pereyra, M.G.; De Martino, M.; Proietti, C.J.; Yankilevich, P.; et al. MiR-16 mediates trastuzumab and lapatinib response in ErbB-2-positive breast and gastric cancer via its novel targets CCNJ and FUBP1. Oncogene 2016, 35, 6189-6202. [CrossRef]

106. Han, M.; Hu, J.; Lu, P.; Cao, H.; Yu, C.; Li, X.; Qian, X.; Yang, X.; Yang, Y.; Han, N.; et al. Exosome-transmitted miR-567 reverses trastuzumab resistance by inhibiting ATG5 in breast cancer. Cell Death Dis. 2020, 11, 1-15. [CrossRef] [PubMed]

107. Bai, W.-D.; Ye, X.-M.; Zhang, M.-Y.; Zhu, H.-Y.; Xi, W.-J.; Huang, X.; Zhao, J.; Gu, B.; Zheng, G.-X.; Yang, A.-G.; et al. MiR-200c suppresses TGF- $\beta$ signaling and counteracts trastuzumab resistance and metastasis by targeting ZNF217 and ZEB1 in breast cancer. Int. J. Cancer 2014, 135, 1356-1368. [CrossRef]

108. Huynh, F.C.; Jones, F.E. MicroRNA-7 Inhibits Multiple Oncogenic Pathways to Suppress HER2 16 Mediated Breast Tumorigenesis and Reverse Trastuzumab Resistance. PLoS ONE 2014, 9, e114419. [CrossRef]

109. Wind, N.S.; Holen, I. Multidrug resistance in breast cancer: From in vitro models to clinical studies. Int. J. Breast Cancer 2011, 2011, 967419. [CrossRef]

110. Tiwari, A.K.; Sodani, K.; Dai, C.-L.; Ashby, C.R.J.; Chen, Z.-S. Revisiting the ABCs of multidrug resistance in cancer chemotherapy. Curr. Pharm. Biotechnol. 2011, 12, 570-594. [CrossRef]

111. Kovalchuk, O.; Filkowski, J.; Meservy, J.; Ilnytskyy, Y.; Tryndyak, V.P.; Chekhun, V.F.; Pogribny, I.P. Involvement of microRNA-451 in resistance of the MCF-7 breast cancer cells to chemotherapeutic drug doxorubicin. Mol. Cancer Ther. 2008, 7, 2152-2159. [CrossRef]

112. Cataldo, A.; Cheung, D.G.; Balsari, A.; Tagliabue, E.; Coppola, V.; Iorio, M.V.; Palmieri, D.; Croce, C.M. miR-302b enhances breast cancer cell sensitivity to cisplatin by regulating E2F1 and the cellular DNA damage response. Oncotarget 2016, 7, 786-797. [CrossRef] [PubMed] 
113. Tormo, E.; Ballester, S.; Adam-Artigues, A.; Burgués, O.; Alonso, E.; Bermejo, B.; Menéndez, S.; Zazo, S.; Madoz-Gúrpide, J.; Rovira, A.; et al. The miRNA-449 family mediates doxorubicin resistance in triple-negative breast cancer by regulating cell cycle factors. Sci. Rep. 2019, 9, 5316. [CrossRef] [PubMed]

114. Tan, X.; Peng, J.; Fu, Y.; An, S.; Rezaei, K.; Tabbara, S.; Teal, C.B.; Man, Y.G.; Brem, R.F.; Fu, S.W. miR-638 mediated regulation of BRCA1 affects DNA repair and sensitivity to UV and cisplatin in triple-negative breast cancer. Breast Cancer Res. 2014, 16, 435. [CrossRef] [PubMed]

115. He, X.; Xiao, X.; Dong, L.; Wan, N.; Zhou, Z.; Deng, H.; Zhang, X. MiR-218 regulates cisplatin chemosensitivity in breast cancer by targeting BRCA1. Tumour Biol. J. Int. Soc. Oncodev. Biol. Med. 2015, 36, 2065-2075. [CrossRef]

116. Zhong, S.; Li, W.; Chen, Z.; Xu, J.; Zhao, J. MiR-222 and miR-29a contribute to the drug-resistance of breast cancer cells. Gene 2013, 531, 8-14. [CrossRef]

117. Zhang, B.; Zhao, R.; He, Y.; Fu, X.; Fu, L.; Zhu, Z.; Fu, L.; Dong, J.-T. MicroRNA 100 sensitizes luminal A breast cancer cells to paclitaxel treatment in part by targeting mTOR. Oncotarget 2016, 7, 5702-5714. [CrossRef]

118. Lyu, H.; Wang, S.; Huang, J.; Wang, B.; He, Z.; Liu, B. Survivin-targeting miR-542-3p overcomes HER3 signaling-induced chemoresistance and enhances the antitumor activity of paclitaxel against HER2-overexpressing breast cancer. Cancer Lett. 2018, 420, 97-108. [CrossRef]

119. Gu, X.; Li, J.-Y.; Guo, J.; Li, P.-S.; Zhang, W.-H. Influence of MiR-451 on Drug Resistances of Paclitaxel-Resistant Breast Cancer Cell Line. Med. Sci. Monit. 2015, 21, 3291-3297. [CrossRef]

120. Zhu, Y.; Wu, J.; Li, S.; Ma, R.; Cao, H.; Ji, M.; Jing, C.; Tang, J. The function role of miR-181a in chemosensitivity to adriamycin by targeting Bcl-2 in low-invasive breast cancer cells. Cell. Physiol. Biochem. Int. J. Exp. Cell. Physiol. Biochem. Pharmacol. 2013, 32, 1225-1237. [CrossRef]

121. Rodriguez-Barrueco, R.; Nekritz, E.A.; Bertucci, F.; Yu, J.; Sanchez-Garcia, F.; Zeleke, T.Z.; Gorbatenko, A.; Birnbaum, D.; Ezhkova, E.; Cordon-Cardo, C.; et al. miR-424(322)/503 is a breast cancer tumor suppressor whose loss promotes resistance to chemotherapy. Genes Dev. 2017, 31, 553-566. [CrossRef]

122. Ye, Z.; Hao, R.; Cai, Y.; Wang, X.; Huang, G. Knockdown of miR-221 promotes the cisplatin-inducing apoptosis by targeting the BIM-Bax/Bak axis in breast cancer. Tumor Biol. 2016, 37, 4509-4515. [CrossRef] [PubMed]

123. He, H.; Tian, W.; Chen, H.; Jiang, K. MiR-944 functions as a novel oncogene and regulates the chemoresistance in breast cancer. Tumour Biol. J. Int. Soc. Oncodev. Biol. Med. 2016, 37, 1599-1607. [CrossRef]

124. Körner, C.; Keklikoglou, I.; Bender, C.; Wörner, A.; Münstermann, E.; Wiemann, S. MicroRNA-31 sensitizes human breast cells to apoptosis by direct targeting of protein kinase C epsilon (PKCepsilon). J. Biol. Chem. 2013, 288, 8750-8761. [CrossRef] [PubMed]

125. Tsang, W.P.; Kwok, T.T. Let-7a microRNA suppresses therapeutics-induced cancer cell death by targeting caspase-3. Apoptosis 2008, 13, 1215-1222. [CrossRef] [PubMed]

126. Wang, Z.; Wang, N.; Liu, P.; Chen, Q.; Situ, H.; Xie, T.; Zhang, J.; Peng, C.; Lin, Y.; Chen, J. MicroRNA-25 regulates chemoresistance-associated autophagy in breast cancer cells, a process modulated by the natural autophagy inducer isoliquiritigenin. Oncotarget 2014, 5, 7013-7026. [CrossRef]

127. Wu, D.; Zhang, J.; Lu, Y.; Bo, S.; Li, L.; Wang, L.; Zhang, Q.; Mao, J. miR-140-5p inhibits the proliferation and enhances the efficacy of doxorubicin to breast cancer stem cells by targeting Wnt1. Cancer Gene Ther. 2019, 26, 74-82. [CrossRef]

128. Zuo, J.; Yu, Y.; Zhu, M.; Jing, W.; Yu, M.; Chai, H.; Liang, C.; Tu, J. Inhibition of miR-155, a therapeutic target for breast cancer, prevented in cancer stem cell formation. Cancer Biomark. 2018, 21, 383-392. [CrossRef]

129. Xie, Q.; Wang, S.; Zhao, Y.; Zhang, Z.; Qin, C.; Yang, X. MiR-519d impedes cisplatin-resistance in breast cancer stem cells by down-regulating the expression of MCL-1. Oncotarget 2017, 8, 22003-22013. [CrossRef]

130. Hu, W.; Tan, C.; He, Y.; Zhang, G.; Xu, Y.; Tang, J. Functional miRNAs in breast cancer drug resistance. OncoTargets Ther. 2018, 11, 1529-1541. [CrossRef]

131. Bockhorn, J.; Dalton, R.; Nwachukwu, C.; Huang, S.; Prat, A.; Yee, K.; Chang, Y.F.; Huo, D.; Wen, Y.; Swanson, K.E.; et al. MicroRNA-30c inhibits human breast tumour chemotherapy resistance by regulating TWF1 and IL-11. Nat. Commun. 2013, 4,1-14. [CrossRef]

132. Ozawa, P.M.M.; Alkhilaiwi, F.; Cavalli, I.J.; Malheiros, D.; de Souza Fonseca Ribeiro, E.M.; Cavalli, L.R. Extracellular vesicles from triple-negative breast cancer cells promote proliferation and drug resistance in non-tumorigenic breast cells. Breast Cancer Res. Treat. 2018, 172, 713-723. [CrossRef] [PubMed] 
133. Shimono, Y.; Zabala, M.; Cho, R.W.; Lobo, N.; Dalerba, P.; Qian, D.; Diehn, M.; Liu, H.; Panula, S.P.; Chiao, E.; et al. Downregulation of miRNA-200c links breast cancer stem cells with normal stem cells. Cell 2009, 138, 592-603. [CrossRef] [PubMed]

134. Knezevic, J.; Pfefferle, A.D.; Petrovic, I.; Greene, S.B.; Perou, C.M.; Rosen, J.M. Expression of miR-200c in claudin-low breast cancer alters stem cell functionality, enhances chemosensitivity and reduces metastatic potential. Oncogene 2015, 34, 5997-6006. [CrossRef]

135. Yu, D.-D.; Wu, Y.; Zhang, X.-H.; Lv, M.-M.; Chen, W.-X.; Chen, X.; Yang, S.-J.; Shen, H.; Zhong, S.-L.; Tang, J.-H.; et al. Exosomes from adriamycin-resistant breast cancer cells transmit drug resistance partly by delivering miR-222. Tumour Biol. J. Int. Soc. Oncodev. Biol. Med. 2016, 37, 3227-3235. [CrossRef]

136. Li, X.J.; Ren, Z.J.; Tang, J.H.; Yu, Q. Exosomal MicroRNA MiR-1246 Promotes Cell Proliferation, Invasion and Drug Resistance by Targeting CCNG2 in Breast Cancer. Cell. Physiol. Biochem. Int. J. Exp. Cell. Physiol. Biochem. Pharmacol. 2017, 44, 1741-1748. [CrossRef] [PubMed]

137. Li, Y.; Liang, Y.; Sang, Y.; Song, X.; Zhang, H.; Liu, Y.; Jiang, L.; Yang, Q. MiR-770 suppresses the chemo-resistance and metastasis of triple negative breast cancer via direct targeting of STMN1. Cell Death Dis. 2018, 9, 14. [CrossRef]

138. Rameshwar, P. Breast cancer cell dormancy in bone marrow: Potential therapeutic targets within the marrow microenvironment. Expert Rev. Anticancer Ther. 2010, 10, 129-132. [CrossRef]

139. Sueta, A.; Yamamoto, Y.; Iwase, H. The role of exosomal microRNAs; focus on clinical applications in breast cancer. Cancer Drug Resist. 2019. [CrossRef]

140. Ono, M.; Kosaka, N.; Tominaga, N.; Yoshioka, Y.; Takeshita, F.; Takahashi, R.; Yoshida, M.; Tsuda, H.; Tamura, K.; Ochiya, T. Exosomes from bone marrow mesenchymal stem cells contain a microRNA that promotes dormancy in metastatic breast cancer cells. Sci. Signal. 2014, 7, ra63. [CrossRef]

141. Bliss, S.A.; Sinha, G.; Sandiford, O.A.; Williams, L.M.; Engelberth, D.J.; Guiro, K.; Isenalumhe, L.L.; Greco, S.J.; Ayer, S.; Bryan, M.; et al. Mesenchymal Stem Cell-Derived Exosomes Stimulate Cycling Quiescence and Early Breast Cancer Dormancy in Bone Marrow. Cancer Res. 2016, 76, 5832-5844. [CrossRef]

142. Wang, W.; Zhang, L.; Wang, Y.; Ding, Y.; Chen, T.; Wang, Y.; Wang, H.; Li, Y.; Duan, K.; Chen, S.; et al. Involvement of miR-451 in resistance to paclitaxel by regulating YWHAZ in breast cancer. Cell Death Dis. 2017, 8, e3071. [CrossRef]

143. Bao, L.; Hazari, S.; Mehra, S.; Kaushal, D.; Moroz, K.; Dash, S. Increased expression of P-glycoprotein and doxorubicin chemoresistance of metastatic breast cancer is regulated by miR-298. Am. J. Pathol. 2012, 180, 2490-2503. [CrossRef] [PubMed]

144. Liang, Z.; Wu, H.; Xia, J.; Li, Y.; Zhang, Y.; Huang, K.; Wagar, N.; Yoon, Y.; Cho, H.T.; Scala, S.; et al. Involvement of miR-326 in chemotherapy resistance of breast cancer through modulating expression of multidrug resistance-associated protein 1. Biochem. Pharmacol. 2010, 79, 817-824. [CrossRef] [PubMed]

145. He, D.-X.; Gu, X.-T.; Jiang, L.; Jin, J.; Ma, X. A methylation-based regulatory network for microRNA 320a in chemoresistant breast cancer. Mol. Pharmacol. 2014, 86, 536-547. [CrossRef] [PubMed]

146. Gao, M.; Miao, L.; Liu, M.; Li, C.; Yu, C.; Yan, H.; Yin, Y.; Wang, Y.; Qi, X.; Ren, J. miR-145 sensitizes breast cancer to doxorubicin by targeting multidrug resistance-associated protein-1. Oncotarget 2016, 7, 59714-59726. [CrossRef]

147. Qian, P.X.; Banerjee, A.; Wu, Z.S.; Zhang, X.; Wang, H.; Pandey, V.; Zhang, W.J.; Lv, X.F.; Tan, S.; Lobie, P.E.; et al. Loss of SNAIL regulated miR-128-2 on chromosome 3p22.3 targets multiple stem cell factors to promote transformation of mammary epithelial cells. Cancer Res. 2012, 72, 6036-6050. [CrossRef] [PubMed]

148. Ma, M.-T.; He, M.; Wang, Y.; Jiao, X.-Y.; Zhao, L.; Bai, X.-F.; Yu, Z.-J.; Wu, H.-Z.; Sun, M.-L.; Song, Z.-G.; et al. MiR-487a resensitizes mitoxantrone (MX)-resistant breast cancer cells (MCF-7/MX) to MX by targeting breast cancer resistance protein (BCRP/ABCG2). Cancer Lett. 2013, 339, 107-115. [CrossRef]

149. Zhu, W.-J.; Chen, X.; Wang, Y.-W.; Liu, H.-T.; Ma, R.-R.; Gao, P. MiR-1268b confers chemosensitivity in breast cancer by targeting ERBB2-mediated PI3K-AKT pathway. Oncotarget 2017, 8, 89631-89642. [CrossRef]

150. Li, X.; Ji, M.; Zhong, S.; Zha, Q.; Xu, J.; Zhao, J.; Tang, J. MicroRNA-34a modulates chemosensitivity of breast cancer cells to adriamycin by targeting Notch1. Arch. Med. Res. 2012, 43, 514-521. [CrossRef]

151. Li, Z.-H.; Weng, X.; Xiong, Q.-Y.; Tu, J.-H.; Xiao, A.; Qiu, W.; Gong, Y.; Hu, E.-W.; Huang, S.; Cao, Y.-L. miR-34a expression in human breast cancer is associated with drug resistance. Oncotarget 2017, 8, 106270-106282. [CrossRef] 
152. Wu, M.-Y.; Fu, J.; Xiao, X.; Wu, J.; Wu, R.-C. MiR-34a regulates therapy resistance by targeting HDAC1 and HDAC7 in breast cancer. Cancer Lett. 2014, 354, 311-319. [CrossRef] [PubMed]

153. Shen, H.; Li, L.; Yang, S.; Wang, D.; Zhong, S.; Zhao, J.; Tang, J. MicroRNA-29a contributes to drug-resistance of breast cancer cells to adriamycin through PTEN/AKT/GSK3 $\beta$ signaling pathway. Gene 2016, 593, 84-90. [CrossRef] [PubMed]

154. Dai, H.; Xu, L.-Y.; Qian, Q.; Zhu, Q.-W.; Chen, W.-X. MicroRNA-222 promotes drug resistance to doxorubicin in breast cancer via regulation of miR-222/bim pathway. Biosci. Rep. 2019, 39, BSR20190650. [CrossRef] [PubMed]

155. Wang, D.; Yang, S.; Chen, X.; Shen, H.-Y.; Luo, L.; Zhang, X.; Zhong, S.; Zhao, J.; Tang, J. miR-222 induces Adriamycin resistance in breast cancer through PTEN/Akt/p27kip1 pathway. Tumor Biol. 2016, 37, 15315-15324. [CrossRef] [PubMed]

156. Lee, J.-W.; Guan, W.; Han, S.; Hong, D.-K.; Kim, L.-S.; Kim, H. MicroRNA-708-3p mediates metastasis and chemoresistance through inhibition of epithelial-to-mesenchymal transition in breast cancer. Cancer Sci. 2018, 109, 1404-1413. [CrossRef] [PubMed]

157. Lv, J.; Xia, K.; Xu, P.; Sun, E.; Ma, J.; Gao, S.; Zhou, Q.; Zhang, M.; Wang, F.; Chen, F.; et al. miRNA expression patterns in chemoresistant breast cancer tissues. Biomed. Pharmacother. 2014, 68, 935-942. [CrossRef]

158. Zhang, X.; Zhong, S.; Xu, Y.; Yu, D.; Ma, T.; Chen, L.; Zhao, Y.; Chen, X.; Yang, S.; Wu, Y.; et al. MicroRNA-3646 Contributes to Docetaxel Resistance in Human Breast Cancer Cells by GSK-3 $\beta / \beta$-Catenin Signaling Pathway. PLoS ONE 2016, 11, e0153194. [CrossRef]

159. Feng, X.; Zhao, L.; Gao, S.; Song, X.; Dong, W.; Zhao, Y.; Zhou, H.; Cheng, L.; Miao, X.; Jia, L. Increased fucosylation has a pivotal role in multidrug resistance of breast cancer cells through miR-224-3p targeting FUT4. Gene 2016, 578, 232-241. [CrossRef]

160. Long, J.; Ji, Z.; Jiang, K.; Wang, Z.; Meng, G. miR-193b Modulates Resistance to Doxorubicin in Human Breast Cancer Cells by Downregulating MCL-1. Biomed. Res. Int. 2015, 2015, 373574. [CrossRef]

161. Wang, Z.-X.; Lu, B.-B.; Wang, H.; Cheng, Z.-X.; Yin, Y.-M. MicroRNA-21 modulates chemosensitivity of breast cancer cells to doxorubicin by targeting PTEN. Arch. Med. Res. 2011, 42, 281-290. [CrossRef]

162. Yuan, Y.; Yao, Y.F.; Hu, S.N.; Gao, J.; Zhang, L.-L. MiR-133a Is Functionally Involved in Doxorubicin-Resistance in Breast Cancer Cells MCF-7 via Its Regulation of the Expression of Uncoupling Protein 2. PLoS ONE 2015, 10, e0129843. [CrossRef]

163. Yu, S.-J.; Yang, L.; Hong, Q.; Kuang, X.-Y.; Di, G.-H.; Shao, Z.-M. MicroRNA-200a confers chemoresistance by antagonizing TP53INP1 and YAP1 in human breast cancer. BMC Cancer 2018, 18, 74. [CrossRef] [PubMed]

164. He, D.-X.; Gu, X.-T.; Li, Y.-R.; Jiang, L.; Jin, J.; Ma, X. Methylation-regulated miR-149 modulates chemoresistance by targeting GlcNAc $N$-deacetylase/ $N$-sulfotransferase- 1 in human breast cancer. FEBS J. 2014, 281, 4718-4730. [CrossRef] [PubMed]

165. Yao, Y.-S.; Qiu, W.-S.; Yao, R.-Y.; Zhang, Q.; Zhuang, L.-K.; Zhou, F.; Sun, L.-B.; Yue, L. miR-141 confers docetaxel chemoresistance of breast cancer cells via regulation of EIF4E expression. Oncol. Rep. 2015, 33, 2504-2512. [CrossRef] [PubMed]

166. Xie, X.; Hu, Y.; Xu, L.; Fu, Y.; Tu, J.; Zhao, H.; Zhang, S.; Hong, R.; Gu, X. The role of miR-125b-mitochondria-caspase-3 pathway in doxorubicin resistance and therapy in human breast cancer. Tumor Biol. 2015, 36, 7185-7194. [CrossRef] [PubMed]

167. Yang, Q.; Wang, Y.; Lu, X.; Zhao, Z.; Zhu, L.; Chen, S.; Wu, Q.; Chen, C.; Wang, Z. MiR-125b regulates epithelial-mesenchymal transition via targeting Sema4C in paclitaxel-resistant breast cancer cells. Oncotarget 2015, 6, 3268-3279. [CrossRef] [PubMed]

168. Zhou, M.; Liu, Z.; Zhao, Y.; Ding, Y.; Liu, H.; Xi, Y.; Xiong, W.; Li, G.; Lu, J.; Fodstad, O.; et al. MicroRNA-125b confers the resistance of breast cancer cells to paclitaxel through suppression of pro-apoptotic Bcl-2 antagonist killer 1 (Bak1) expression. J. Biol. Chem. 2010, 285, 21496-21507. [CrossRef]

169. Hu, G.; Zhao, X.; Wang, J.; Lv, L.; Wang, C.; Feng, L.; Shen, L.; Ren, W. miR-125b regulates the drug-resistance of breast cancer cells to doxorubicin by targeting HAX-1. Oncol. Lett. 2018, 15, 1621-1629. [CrossRef]

170. Zhang, Y.; Wang, Y.; Wei, Y.; Li, M.; Yu, S.; Ye, M.; Zhang, H.; Chen, S.; Liu, W.; Zhang, J. MiR-129-3p promotes docetaxel resistance of breast cancer cells via CP110 inhibition. Sci. Rep. 2015, 5, 1-12. [CrossRef]

171. Zhang, H.; Sun, D.; Mao, L.; Zhang, J.; Jiang, L.; Li, J.; Wu, Y.; Ji, H.; Chen, W.; Wang, J.; et al. MiR-139-5p inhibits the biological function of breast cancer cells by targeting Notch1 and mediates chemosensitivity to docetaxel. Biochem. Biophys. Res. Commun. 2015, 465, 702-713. [CrossRef] [PubMed] 
172. Hu, S.-H.; Wang, C.-H.; Huang, Z.-J.; Liu, F.; Xu, C.-W.; Li, X.-L.; Chen, G.-Q. miR-760 mediates chemoresistance through inhibition of epithelial mesenchymal transition in breast cancer cells. Eur. Rev. Med. Pharmacol. Sci. 2016, 20, 5002-5008. [PubMed]

173. Ye, F.G.; Song, C.G.; Cao, Z.G.; Xia, C.; Chen, D.N.; Chen, L.; Li, S.; Qiao, F.; Ling, H.; Yao, L.; et al. Cytidine deaminase axis modulated by mir-484 differentially regulates cell proliferation and chemoresistance in breast cancer. Cancer Res. 2015, 75, 1504-1515. [CrossRef]

174. Wang, X.; Wang, X.; Gu, J.; Zhou, M.; He, Z.; Wang, X.; Ferrone, S. Overexpression of miR-489 enhances efficacy of 5-fluorouracil-based treatment in breast cancer stem cells by targeting XIAP. Oncotarget 2017, 8, 113837-113846. [CrossRef] [PubMed]

175. Chen, X.; Wang, Y.-W.; Xing, A.-Y.; Xiang, S.; Shi, D.-B.; Liu, L.; Li, Y.-X.; Gao, P. Suppression of SPIN1-mediated PI3K-Akt pathway by miR-489 increases chemosensitivity in breast cancer. J. Pathol. 2016, 239, 459-472. [CrossRef] [PubMed]

176. Jiang, L.; He, D.; Yang, D.; Chen, Z.; Pan, Q.; Mao, A.; Cai, Y.; Li, X.; Xing, H.; Shi, M.; et al. MiR-489 regulates chemoresistance in breast cancer via epithelial mesenchymal transition pathway. FEBS Lett. 2014, 588, 2009-2015. [CrossRef]

177. Hu, H.; Li, S.; Cui, X.; Lv, X.; Jiao, Y.; Yu, F.; Yao, H.; Song, E.; Chen, Y.; Wang, M.; et al. The overexpression of hypomethylated miR-663 induces chemotherapy resistance in human breast cancer cells by targeting heparin sulfate proteoglycan 2 (HSPG2). J. Biol. Chem. 2013, 288, 10973-10985. [CrossRef]

178. Kopp, F.; Oak, P.S.; Wagner, E.; Roidl, A. miR-200c Sensitizes Breast Cancer Cells to Doxorubicin Treatment by Decreasing TrkB and Bmi1 Expression. PLoS ONE 2012, 7, e50469. [CrossRef]

179. Li, H.-Y.; Liang, J.-L.; Kuo, Y.-L.; Lee, H.-H.; Calkins, M.J.; Chang, H.-T.; Lin, F.-C.; Chen, Y.-C.; Hsu, T.-I.; Hsiao, M.; et al. miR-105/93-3p promotes chemoresistance and circulating miR-105/93-3p acts as a diagnostic biomarker for triple negative breast cancer. Breast Cancer Res. 2017, 19, 133. [CrossRef]

180. Roscigno, G.; Puoti, I.; Giordano, I.; Donnarumma, E.; Russo, V.; Affinito, A.; Adamo, A.; Quintavalle, C.; Todaro, M.; dM Vivanco, M.; et al. MiR-24 induces chemotherapy resistance and hypoxic advantage in breast cancer. Oncotarget 2017, 8, 19507-19521. [CrossRef]

181. Si, W.; Shen, J.; Du, C.; Chen, D.; Gu, X.; Li, C.; Yao, M.; Pan, J.; Cheng, J.; Jiang, D.; et al. A miR-20a/MAPK1/c-Myc regulatory feedback loop regulates breast carcinogenesis and chemoresistance. Cell Death Differ. 2018, 25, 406-420. [CrossRef]

182. Jiao, X.; Zhao, L.; Ma, M.; Bai, X.; He, M.; Yan, Y.; Wang, Y.; Chen, Q.; Zhao, X.; Zhou, M.; et al. MiR-181a enhances drug sensitivity in mitoxantone-resistant breast cancer cells by targeting breast cancer resistance protein (BCRP/ABCG2). Breast Cancer Res. Treat. 2013, 139, 717-730. [CrossRef]

183. Niu, J.; Xue, A.; Chi, Y.; Xue, J.; Wang, W.; Zhao, Z.; Fan, M.; Yang, C.H.; Shao, Z.M.; Pfeffer, L.M.; et al. Induction of miRNA-181a by genotoxic treatments promotes chemotherapeutic resistance and metastasis in breast cancer. Oncogene 2016, 35, 1302-1313. [CrossRef]

184. Su, C.-M.; Wang, M.-Y.; Hong, C.-C.; Chen, H.-A.; Su, Y.-H.; Wu, C.-H.; Huang, M.-T.; Chang, Y.-W.; Jiang, S.-S.; Sung, S.-Y.; et al. miR-520h is crucial for DAPK2 regulation and breast cancer progression. Oncogene 2016, 35 , 1134-1142. [CrossRef]

185. Sha, L.-Y.; Zhang, Y.; Wang, W.; Sui, X.; Liu, S.-K.; Wang, T.; Zhang, H. MiR-18a upregulation decreases Dicer expression and confers paclitaxel resistance in triple negative breast cancer. Eur. Rev. Med. Pharmacol. Sci. 2016, 20, 2201-2208. [PubMed]

186. Liu, X.; Tang, H.; Chen, J.; Song, C.; Yang, L.; Liu, P.; Wang, N.; Xie, X.; Lin, X.; Xie, X. MicroRNA-101 inhibits cell progression and increases paclitaxel sensitivity by suppressing MCL-1 expression in human triple-negative breast cancer. Oncotarget 2015, 6, 20070-20083. [CrossRef] [PubMed]

187. Fan, X.; Zhou, S.; Zheng, M.; Deng, X.; Yi, Y.; Huang, T. MiR-199a-3p enhances breast cancer cell sensitivity to cisplatin by downregulating TFAM (TFAM). Biomed. Pharmacother. 2017, 88, 507-514. [CrossRef] [PubMed]

188. Rinn, J.L.; Chang, H.Y. Genome regulation by long noncoding RNAs. Annu. Rev. Biochem. 2012, 81, $145-166$. [CrossRef]

189. Flynn, R.A.; Chang, H.Y. Long noncoding RNAs in cell-fate programming and reprogramming. Cell Stem Cell 2014, 14, 752-761. [CrossRef]

190. Jiang, C.; Li, Y.; Zhao, Z.; Lu, J.; Chen, H.; Ding, N.; Wang, G.; Xu, J.; Li, X. Identifying and functionally characterizing tissue-specific and ubiquitously expressed human lncRNAs. Oncotarget 2016, 7, 7120-7133. [CrossRef] 
191. Mattioli, K.; Volders, P.J.; Gerhardinger, C.; Lee, J.C.; Maass, P.G.; Melé, M.; Rinn, J.L. High-throughput functional analysis of lncRNA core promoters elucidates rules governing tissue specificity. Genome Res. 2019, 29, 344-355. [CrossRef]

192. Richard, J.L.C.; Eichhorn, P.J.A. Deciphering the roles of lncRNAs in breast development and disease. Oncotarget 2018, 9, 20179-20212. [CrossRef] [PubMed]

193. Ponting, C.P.; Oliver, P.L.; Reik, W. Evolution and functions of long noncoding RNAs. Cell 2009, 136, 629-641. [CrossRef] [PubMed]

194. Rinn, J.L.; Kertesz, M.; Wang, J.K.; Squazzo, S.L.; Xu, X.; Brugmann, S.A.; Goodnough, L.H.; Helms, J.A.; Farnham, P.J.; Segal, E.; et al. Functional demarcation of active and silent chromatin domains in human HOX loci by noncoding RNAs. Cell 2007, 129, 1311-1323. [CrossRef]

195. Wang, K.C.; Chang, H.Y. Molecular mechanisms of long noncoding RNAs. Mol. Cell 2011, 43, $904-914$. [CrossRef] [PubMed]

196. Yao, R.-W.; Wang, Y.; Chen, L.-L. Cellular functions of long noncoding RNAs. Nat. Cell Biol. 2019, $21,542-551$. [CrossRef]

197. Flicek, P.; Amode, M.R.; Barrell, D.; Beal, K.; Billis, K.; Brent, S.; Carvalho-Silva, D.; Clapham, P.; Coates, G.; Fitzgerald, S.; et al. Ensembl 2014. Nucleic Acids Res. 2014, 42, D749-D755. [CrossRef]

198. Fatica, A.; Bozzoni, I. Long non-coding RNAs: New players in cell differentiation and development. Nat. Rev. Genet. 2014, 15, 7-21. [CrossRef]

199. Gibb, E.A.; Brown, C.J.; Lam, W.L. The functional role of long non-coding RNA in human carcinomas. Mol. Cancer 2011, 10, 1-17. [CrossRef]

200. Chen, S.; Zhu, J.; Wang, F.; Guan, Z.; Ge, Y.; Yang, X.; Cai, J. LncRNAs and their role in cancer stem cells. Oncotarget 2017, 8, 110685-110692. [CrossRef]

201. Chou, J.; Wang, B.; Zheng, T.; Li, X.; Zheng, L.; Hu, J.; Zhang, Y.; Xing, Y.; Xi, T. MALAT1 induced migration and invasion of human breast cancer cells by competitively binding miR-1 with cdc42. Biochem. Biophys. Res. Commun. 2016, 472, 262-269. [CrossRef]

202. Zhang, H.-Y.; Liang, F.; Zhang, J.-W.; Wang, F.; Wang, L.; Kang, X.-G. Effects of long noncoding RNA-ROR on tamoxifen resistance of breast cancer cells by regulating microRNA-205. Cancer Chemother. Pharmacol. 2017, 79, 327-337. [CrossRef] [PubMed]

203. Li, Y.; Song, Y.; Wang, Z.; Zhang, Z.; Lu, M.; Wang, Y. Long Non-coding RNA LINC01787 Drives Breast Cancer Progression via Disrupting miR-125b Generation. Front. Oncol. 2019, 9, 1140. [CrossRef] [PubMed]

204. Wang, K.; Li, J.; Xiong, Y.-F.; Zeng, Z.; Zhang, X.; Li, H.-Y. A Potential Prognostic Long Noncoding RNA Signature to Predict Recurrence among ER-positive Breast Cancer Patients Treated with Tamoxifen. Sci. Rep. 2018, 8, 3179. [CrossRef]

205. Xue, X.; Yang, Y.A.; Zhang, A.; Fong, K.-W.; Kim, J.; Song, B.; Li, S.; Zhao, J.C.; Yu, J. LncRNA HOTAIR enhances ER signaling and confers tamoxifen resistance in breast cancer. Oncogene 2016, 35, 2746-2755. [CrossRef] [PubMed]

206. Kim, C.Y.; Oh, J.H.; Lee, J.-Y.; Kim, M.H. The LncRNA HOTAIRM1 Promotes Tamoxifen Resistance by Mediating HOXA1 Expression in ER+ Breast Cancer Cells. J. Cancer 2020, 11, 3416-3423. [CrossRef]

207. Godinho, M.F.E.; Sieuwerts, A.M.; Look, M.P.; Meijer, D.; Foekens, J.A.; Dorssers, L.C.J.; van Agthoven, T. Relevance of BCAR4 in tamoxifen resistance and tumour aggressiveness of human breast cancer. Br. J. Cancer 2010, 103, 1284-1291. [CrossRef]

208. Godinho, M.F.E.; Wulfkuhle, J.D.; Look, M.P.; Sieuwerts, A.M.; Sleijfer, S.; Foekens, J.A.; Petricoin, E.F.; Dorssers, L.C.J.; van Agthoven, T. BCAR4 induces antioestrogen resistance but sensitises breast cancer to lapatinib. Br. J. Cancer 2012, 107, 947-955. [CrossRef]

209. Cai, Y.; He, J.; Zhang, D. Long noncoding RNA CCAT2 promotes breast tumor growth by regulating the Wnt signaling pathway. OncoTargets Ther. 2015, 8, 2657-2664. [CrossRef]

210. Wu, Z.-J.; Li, Y.; Wu, Y.-Z.; Wang, Y.; Nian, W.-Q.; Wang, L.-L.; Li, L.-C.; Luo, H.-L.; Wang, D.-L. Long non-coding RNA CCAT2 promotes the breast cancer growth and metastasis by regulating TGF- $\beta$ signaling pathway. Eur. Rev. Med. Pharmacol. Sci. 2017, 21, 706-714.

211. Cai, Y.; He, J.; Zhang, D. Suppression of long non-coding RNA CCAT2 improves tamoxifen-resistant breast cancer cells' response to tamoxifen]. Mol. Biol. 2016, 50, 821-827. [CrossRef]

212. Peng, W.-X.; Huang, J.-G.; Yang, L.; Gong, A.-H.; Mo, Y.-Y. Linc-RoR promotes MAPK/ERK signaling and confers estrogen-independent growth of breast cancer. Mol. Cancer 2017, 16, 161. [CrossRef] 
213. Li, Z.; Yu, D.; Li, H.; Lv, Y.; Li, S. Long non-coding RNA UCA1 confers tamoxifen resistance in breast cancer endocrinotherapy through regulation of the EZH2/p21 axis and the PI3K/AKT signaling pathway. Int. J. Oncol. 2019, 54, 1033-1042. [CrossRef] [PubMed]

214. Wu, C.; Luo, J. Long Non-Coding RNA (lncRNA) Urothelial Carcinoma-Associated 1 (UCA1) Enhances Tamoxifen Resistance in Breast Cancer Cells via Inhibiting mTOR Signaling Pathway. Med. Sci. Monit. Int. Med. J. Exp. Clin. Res. 2016, 22, 3860-3867. [CrossRef] [PubMed]

215. Liu, H.; Wang, G.; Yang, L.; Qu, J.; Yang, Z.; Zhou, X. Knockdown of Long Non-Coding RNA UCA1 Increases the Tamoxifen Sensitivity of Breast Cancer Cells through Inhibition of Wnt/ $\beta$-Catenin Pathway. PLoS ONE 2016, 11, e0168406. [CrossRef] [PubMed]

216. Li, X.; Wu, Y.; Liu, A.; Tang, X. Long non-coding RNA UCA1 enhances tamoxifen resistance in breast cancer cells through a miR-18a-HIF1 $\alpha$ feedback regulatory loop. Tumour Biol. J. Int. Soc. Oncodev. Biol. Med. 2016, 37, 14733-14743. [CrossRef]

217. Xu, C.-G.; Yang, M.-F.; Ren, Y.-Q.; Wu, C.-H.; Wang, L.-Q. Exosomes mediated transfer of lncRNA UCA1 results in increased tamoxifen resistance in breast cancer cells. Eur. Rev. Med. Pharmacol. Sci. 2016, 20, 4362-4368.

218. Gu, J.; Wang, Y.; Wang, X.; Zhou, D.; Shao, C.; Zhou, M.; He, Z. Downregulation of lncRNA GAS5 confers tamoxifen resistance by activating miR-222 in breast cancer. Cancer Lett. 2018, 434, 1-10. [CrossRef]

219. Gregory, P.A.; Bracken, C.P.; Smith, E.; Bert, A.G.; Wright, J.A.; Roslan, S.; Morris, M.; Wyatt, L.; Farshid, G.; Lim, Y.-Y.; et al. An autocrine TGF-beta/ZEB/miR-200 signaling network regulates establishment and maintenance of epithelial-mesenchymal transition. Mol. Biol. Cell 2011, 22, 1686-1698. [CrossRef]

220. Dong, H.; Wang, W.; Chen, R.; Zhang, Y.; Zou, K.; Ye, M.; He, X.; Zhang, F.; Han, J. Exosome-mediated transfer of lncRNA-SNHG14 promotes trastuzumab chemoresistance in breast cancer. Int. J. Oncol. 2018, 53, 1013-1026. [CrossRef]

221. Sun, Z.; Zhang, C.; Wang, T.; Shi, P.; Tian, X.; Guo, Y. Correlation between long non-coding RNAs (lncRNAs) H19 expression and trastuzumab resistance in breast cancer. J. Cancer Res. Ther. 2019, 15, 933-940. [CrossRef]

222. Zhu, H.-Y.; Bai, W.-D.; Ye, X.-M.; Yang, A.-G.; Jia, L.-T. Long non-coding RNA UCA1 desensitizes breast cancer cells to trastuzumab by impeding miR-18a repression of Yes-associated protein 1. Biochem. Biophys. Res. Commun. 2018, 496, 1308-1313. [CrossRef] [PubMed]

223. Dong, H.; Hu, J.; Zou, K.; Ye, M.; Chen, Y.; Wu, C.; Chen, X.; Han, M. Activation of LncRNA TINCR by H3K27 acetylation promotes Trastuzumab resistance and epithelial-mesenchymal transition by targeting MicroRNA-125b in breast Cancer. Mol. Cancer 2019, 18, 3. [CrossRef] [PubMed]

224. Chen, T.; Liu, Z.; Zeng, W.; Huang, T. Down-regulation of long non-coding RNA HOTAIR sensitizes breast cancer to trastuzumab. Sci. Rep. 2019, 9, 19881. [CrossRef] [PubMed]

225. Li, W.; Zhai, L.; Wang, H.; Liu, C.; Zhang, J.; Chen, W.; Wei, Q. Downregulation of LncRNA GAS5 causes trastuzumab resistance in breast cancer. Oncotarget 2016, 7, 27778-27786. [CrossRef]

226. Hung, T.; Wang, Y.; Lin, M.F.; Koegel, A.K.; Kotake, Y.; Grant, G.D.; Horlings, H.M.; Shah, N.; Umbricht, C.; Wang, P.; et al. Extensive and coordinated transcription of noncoding RNAs within cell-cycle promoters. Nat. Genet. 2011, 43, 621-629. [CrossRef]

227. Jiang, M.; Huang, O.; Xie, Z.; Wu, S.; Zhang, X.; Shen, A.; Liu, H.; Chen, X.; Wu, J.; Lou, Y.; et al. A novel long non-coding RNA-ARA: Adriamycin Resistance Associated. Biochem. Pharmacol. 2014, 87, $254-283$. [CrossRef]

228. Gu, M.; Zheng, W.; Zhang, M.; Dong, X.; Zhao, Y.; Wang, S.; Jiang, H.; Zheng, X. LncRNA NONHSAT141924 promotes paclitaxel chemotherapy resistance through $\mathrm{p}-\mathrm{CREB} / \mathrm{Bcl}-2$ apoptosis signaling pathway in breast cancer. J. Cancer 2020, 11, 3645-3654. [CrossRef]

229. Si, X.; Zang, R.; Zhang, E.; Liu, Y.; Shi, X.; Zhang, E.; Shao, L.; Li, A.; Yang, N.; Han, X.; et al. LncRNA H19 confers chemoresistance in ER $\alpha$-positive breast cancer through epigenetic silencing of the pro-apoptotic gene BIK. Oncotarget 2016, 7, 81452-81462. [CrossRef]

230. Gooding, A.J.; Zhang, B.; Gunawardane, L.; Beard, A.; Valadkhan, S.; Schiemann, W.P. The lncRNA BORG facilitates the survival and chemoresistance of triple-negative breast cancers. Oncogene 2019, 38, 2020-2041. [CrossRef]

231. Xiu, D.-H.; Liu, G.-F.; Yu, S.-N.; Li, L.-Y.; Zhao, G.-Q.; Liu, L.; Li, X.-F. Long non-coding RNA LINC00968 attenuates drug resistance of breast cancer cells through inhibiting the Wnt $/ \beta$-catenin signaling pathway by regulating WNT2. J. Exp. Clin. Cancer Res. 2019, 38, 94. [CrossRef] 
232. Chen, Z.; Pan, T.; Jiang, D.; Jin, L.; Geng, Y.; Feng, X.; Shen, A.; Zhang, L. The lncRNA-GAS5/miR-221-3p/DKK2 Axis Modulates ABCB1-Mediated Adriamycin Resistance of Breast Cancer via the Wnt/ $\beta$-Catenin Signaling Pathway. Mol. Ther. Nucleic Acids 2020, 19, 1434-1448. [CrossRef]

233. Bida, O.; Gidoni, M.; Ideses, D.; Efroni, S.; Ginsberg, D. A novel mitosis-associated lncRNA, MA-linc1, is required for cell cycle progression and sensitizes cancer cells to Paclitaxel. Oncotarget 2015, 6, 27880-27890. [CrossRef] [PubMed]

234. Liu, C.; Jiang, F.; Zhang, X.; Xu, X. Long Non-Coding RNA UCA1 Modulates Paclitaxel Resistance in Breast Cancer via miR-613/CDK12 Axis. Cancer Manag. Res. 2020, 12, 2777-2788. [CrossRef] [PubMed]

235. He, D.-X.; Zhang, G.-Y.; Gu, X.-T.; Mao, A.-Q.; Lu, C.-X.; Jin, J.; Liu, D.-Q.; Ma, X. Genome-wide profiling of long non-coding RNA expression patterns in anthracycline-resistant breast cancer cells. Int. J. Oncol. 2016, 49, 1695-1703. [CrossRef] [PubMed]

236. Liang, Y.; Li, Y.; Song, X.; Zhang, N.; Sang, Y.; Zhang, H.; Liu, Y.; Chen, B.; Zhao, W.; Wang, L.; et al. Long noncoding RNA LINP1 acts as an oncogene and promotes chemoresistance in breast cancer. Cancer Biol. Ther. 2018, 19, 120-131. [CrossRef] [PubMed]

237. Gao, J.; Yuan, Y.; Zhang, L.; Yu, S.; Lu, J.; Feng, J.; Hu, S. Inhibition of ZEB1-AS1 confers cisplatin sensitivity in breast cancer by promoting microRNA-129-5p-dependent ZEB1 downregulation. Cancer Cell Int. 2020, 20, 90. [CrossRef] [PubMed]

238. Chen, Y.-M.; Liu, Y.; Wei, H.-Y.; Lv, K.-Z.; Fu, P. Linc-ROR induces epithelial-mesenchymal transition and contributes to drug resistance and invasion of breast cancer cells. Tumour Biol. J. Int. Soc. Oncodev. Biol. Med. 2016, 37, 10861-10870. [CrossRef]

239. Fultang, N.; Illendula, A.; Lin, J.; Pandey, M.K.; Klase, Z.; Peethambaran, B. ROR1 regulates chemoresistance in Breast Cancer via modulation of drug efflux pump ABCB1. Sci. Rep. 2020, 10, 1821. [CrossRef]

240. Wang, G.; Chen, X.; Liang, Y.; Wang, W.; Shen, K. A Long Noncoding RNA Signature That Predicts Pathological Complete Remission Rate Sensitively in Neoadjuvant Treatment of Breast Cancer. Transl. Oncol. 2017, 10, 988-997. [CrossRef]

241. Zeng, Y.; Wang, G.; Zhou, C.-F.; Zhang, H.-B.; Sun, H.; Zhang, W.; Zhou, H.-H.; Liu, R.; Zhu, Y.-S. LncRNA Profile Study Reveals a Three-LncRNA Signature Associated With the Pathological Complete Response Following Neoadjuvant Chemotherapy in Breast Cancer. Front. Pharmacol. 2019, 10, 574. [CrossRef]

242. Zhang, Y.; He, Q.; Hu, Z.; Feng, Y.; Fan, L.; Tang, Z.; Yuan, J.; Shan, W.; Li, C.; Hu, X.; et al. Long noncoding RNA LINP1 regulates repair of DNA double-strand breaks in triple-negative breast cancer. Nat. Struct. Mol. Biol. 2016, 23, 522-530. [CrossRef]

243. Hu, X.-L.; Wang, J.; He, W.; Zhao, P.; Wu, W.-Q. Down-regulation of lncRNA Linc00152 suppressed cell viability, invasion, migration, and epithelial to mesenchymal transition, and reversed chemo-resistance in breast cancer cells. Eur. Rev. Med. Pharmacol. Sci. 2018, 22, 3074-3084. [CrossRef] [PubMed]

244. Huang, L.; Zeng, L.; Chu, J.; Xu, P.; Lv, M.; Xu, J.; Wen, J.; Li, W.; Wang, L.; Wu, X.; et al. Chemoresistance-related long non-coding RNA expression profiles in human breast cancer cells. Mol. Med. Rep. 2018, 18, $243-253$. [CrossRef] [PubMed]

245. Liang, Y.; Song, X.; Li, Y.; Sang, Y.; Zhang, N.; Zhang, H.; Liu, Y.; Duan, Y.; Chen, B.; Guo, R.; et al. A novel long non-coding RNA-PRLB acts as a tumor promoter through regulating miR-4766-5p/SIRT1 axis in breast cancer. Cell Death Dis. 2018, 9, 563. [CrossRef] [PubMed]

246. Balachandran, V.P.; Gonen, M.; Smith, J.J.; DeMatteo, R.P. Nomograms in oncology: More than meets the eye. Lancet. Oncol. 2015, 16, e173-e180. [CrossRef]

247. Lai, J.; Wang, H.; Pan, Z.; Su, F. A novel six-microRNA-based model to improve prognosis prediction of breast cancer. Aging (Albany NY) 2019, 11, 649-662. [CrossRef]

248. Rodríguez-González, F.G.; Sieuwerts, A.M.; Smid, M.; Look, M.P.; Meijer-Van Gelder, M.E.; De Weerd, V.; Sleijfer, S.; Martens, J.W.M.; Foekens, J.A. MicroRNA-30c expression level is an independent predictor of clinical benefit of endocrine therapy in advanced estrogen receptor positive breast cancer. Breast Cancer Res. Treat. 2011, 127, 43-51. [CrossRef]

249. Uhr, K.; Sieuwerts, A.M.; De Weerd, V.; Smid, M.; Hammerl, D.; Foekens, J.A.; Martens, J.W.M. Association of microRNA-7 and its binding partner CDR1-AS with the prognosis and prediction of 1st-line tamoxifen therapy in breast cancer. Sci. Rep. 2018, 8, 1-14. [CrossRef] 
250. Wu, X.; Somlo, G.; Yu, Y.; Palomares, M.R.; Li, A.X.; Zhou, W.; Chow, A.; Yen, Y.; Rossi, J.J.; Gao, H.; et al. De novo sequencing of circulating miRNAs identifies novel markers predicting clinical outcome of locally advanced breast cancer. J. Transl. Med. 2012, 10, 42. [CrossRef]

251. Falkenberg, N.; Anastasov, N.; Rappl, K.; Braselmann, H.; Auer, G.; Walch, A.; Huber, M.; Höfig, I.; Schmitt, M.; Höfler, H.; et al. MiR-221/-222 differentiate prognostic groups in advanced breast cancers and influence cell invasion. Br. J. Cancer 2013, 109, 2714-2723. [CrossRef]

252. Li, Y.; Zhang, L.; Dong, Z.; Xu, H.; Yan, L.; Yang, S.; Chen, T.; Chen, S.; Wang, W.; Yang, Q.; et al. MicroRNA-155-5p promotes tumor progression and contributes paclitaxel resistance to chemotherapy via TP53INP1 in human Breast Cancer. Research Square 2020. [CrossRef]

253. Chandra Gupta, S.; Nandan Tripathi, Y. Potential of long non-coding RNAs in cancer patients: From biomarkers to therapeutic targets. Int. J. Cancer 2017, 140, 1955-1967. [CrossRef] [PubMed]

254. Tang, J.; Cui, Q.; Zhang, D.; Kong, D.; Liao, X.; Ren, J.; Gong, Y.; Wu, G. A prognostic eight-lncRNA expression signature in predicting recurrence of ER-positive breast cancer receiving endocrine therapy. J. Cell. Physiol. 2020, 235, 4746-4755. [CrossRef]

255. Jiang, Y.-Z.; Liu, Y.-R.; Xu, X.-E.; Jin, X.; Hu, X.; Yu, K.-D.; Shao, Z.-M. Transcriptome Analysis of Triple-Negative Breast Cancer Reveals an Integrated mRNA-lncRNA Signature with Predictive and Prognostic Value. Cancer Res. 2016, 76, 2105-2114. [CrossRef] [PubMed]

256. Zhong, X.; Xie, G.; Zhang, Z.; Wang, Z.; Wang, Y.; Wang, Y.; Qiu, Y.; Li, L.; Bu, H.; Li, J.; et al. MiR-4653-3p and its target gene FRS2 are prognostic biomarkers for hormone receptor positive breast cancer patients receiving tamoxifen as adjuvant endocrine therapy. Oncotarget 2016, 7, 61166-61182. [CrossRef]

257. Amorim, M.; Lobo, J.; Fontes-Sousa, M.; Estevão-Pereira, H.; Salta, S.; Lopes, P.; Coimbra, N.; Antunes, L.; Palma de Sousa, S.; Henrique, R.; et al. Predictive and Prognostic Value of Selected MicroRNAs in Luminal Breast Cancer. Front. Genet. 2019, 10, 815. [CrossRef]

258. Li, W.; Jin, X.; Zhang, Q.; Zhang, G.; Deng, X.; Ma, L. Decreased expression of miR-204 is associated with poor prognosis in patients with breast cancer. Int. J. Clin. Exp. Pathol. 2014, 7, 3287-3292.

259. Bleckmann, A.; Leha, A.; Artmann, S.; Menck, K.; Salinas-Riester, G.; Binder, C.; Pukrop, T.; Beissbarth, T.; Klemm, F. Integrated miRNA and mRNA profiling of tumor-educated macrophages identifies prognostic subgroups in estrogen receptor-positive breast cancer. Mol. Oncol. 2015, 9, 155-166. [CrossRef]

260. Rothé, F.; Ignatiadis, M.; Chaboteaux, C.; Haibe-Kains, B.; Kheddoumi, N.; Majjaj, S.; Badran, B.; Fayyad-Kazan, H.; Desmedt, C.; Harris, A.L.; et al. Global microRNA expression profiling identifies MiR-210 associated with tumor proliferation, invasion and poor clinical outcome in breast cancer. PLoS ONE 2011, 6, e20980. [CrossRef]

261. Camps, C.; Buffa, F.M.; Colella, S.; Moore, J.; Sotiriou, C.; Sheldon, H.; Harris, A.L.; Gleadle, J.M.; Ragoussis, J. hsa-miR-210 Is induced by hypoxia and is an independent prognostic factor in breast cancer. Clin. Cancer Res. Off. J. Am. Assoc. Cancer Res. 2008, 14, 1340-1348. [CrossRef]

262. Vilquin, P.; Donini, C.F.; Villedieu, M.; Grisard, E.; Corbo, L.; Bachelot, T.; Vendrell, J.A.; Cohen, P.A. MicroRNA-125b upregulation confers aromatase inhibitor resistance and is a novel marker of poor prognosis in breast cancer. Breast Cancer Res. 2015, 17, 13. [CrossRef] [PubMed]

263. Zhang, L.; Cao, X.; Zhang, L.; Zhang, X.; Sheng, H.; Tao, K. UCA1 overexpression predicts clinical outcome of patients with ovarian cancer receiving adjuvant chemotherapy. Cancer Chemother. Pharmacol. 2016, 77, 629-634. [CrossRef]

264. Chen, X.; Lu, P.; Wang, D.-D.; Yang, S.-J.; Wu, Y.; Shen, H.-Y.; Zhong, S.-L.; Zhao, J.-H.; Tang, J.-H. The role of miRNAs in drug resistance and prognosis of breast cancer formalin-fixed paraffin-embedded tissues. Gene 2016, 595, 221-226. [CrossRef] [PubMed]

265. Liu, B.; Su, F.; Chen, M.; Li, Y.; Qi, X.; Xiao, J.; Li, X.; Liu, X.; Liang, W.; Zhang, Y.; et al. Serum miR-21 and miR-125b as markers predicting neoadjuvant chemotherapy response and prognosis in stage II/III breast cancer. Hum. Pathol. 2017, 64, 44-52. [CrossRef] [PubMed]

266. Wang, X.; Yang, B.; Ma, B. The UCA1/miR-204/Sirt1 axis modulates docetaxel sensitivity of prostate cancer cells. Cancer Chemother. Pharmacol. 2016, 78, 1025-1031. [CrossRef]

267. Bian, Z.; Jin, L.; Zhang, J.; Yin, Y.; Quan, C.; Hu, Y.; Feng, Y.; Liu, H.; Fei, B.; Mao, Y.; et al. LncRNA-UCA1 enhances cell proliferation and 5-fluorouracil resistance in colorectal cancer by inhibiting MIR-204-5p. Sci. Rep. 2016, 6, 1-12. [CrossRef] 
268. Xiao, Y.; Jiao, C.; Lin, Y.; Chen, M.; Zhang, J.; Wang, J.; Zhang, Z. lncRNA UCA1 Contributes to Imatinib Resistance by Acting as a ceRNA Against miR-16 in Chronic Myeloid Leukemia Cells. DNA Cell Biol. 2017, 36, 18-25. [CrossRef]

269. Pan, J.; Li, X.; Wu, W.; Xue, M.; Hou, H.; Zhai, W.; Chen, W. Long non-coding RNA UCA1 promotes cisplatin/gemcitabine resistance through CREB modulating miR-196a-5p in bladder cancer cells. Cancer Lett. 2016, 382, 64-76. [CrossRef]

270. Fang, Q.; Chen, X.; Zhi, X. Long Non-Coding RNA (LncRNA) Urothelial Carcinoma Associated 1 (UCA1) Increases Multi-Drug Resistance of Gastric Cancer via Downregulating miR-27b. Med. Sci. Monit. 2016, 22, 3506-3513. [CrossRef]

271. Yu, W.-C.; Chen, H.-H.; Qu, Y.-Y.; Xu, C.-W.; Yang, C.; Liu, Y. MicroRNA-221 promotes cisplatin resistance in osteosarcoma cells by targeting PPP2R2A. Biosci. Rep. 2019, 39. [CrossRef]

272. Zhao, L.; Zou, D.; Wei, X.; Wang, L.; Zhang, Y.; Liu, S.; Si, Y.; Zhao, H.; Wang, F.; Yu, J.; et al. MiRNA-221-3p desensitizes pancreatic cancer cells to 5-fluorouracil by targeting RB1. Tumor Biol. 2016, 37, 16053-16063. [CrossRef]

273. Cao, L.; Chen, J.; Ou, B.; Liu, C.; Zou, Y.; Chen, Q. GAS5 knockdown reduces the chemo-sensitivity of non-small cell lung cancer (NSCLC) cell to cisplatin (DDP) through regulating miR-21/PTEN axis. Biomed. Pharmacother. 2017, 93, 570-579. [CrossRef] [PubMed]

274. Gao, Z.-Q.; Wang, J.; Chen, D.-H.; Ma, X.-S.; Yang, W.; Zhe, T.; Dang, X.-W. Long non-coding RNA GAS5 antagonizes the chemoresistance of pancreatic cancer cells through down-regulation of miR-181c-5p. Biomed. Pharmacother. 2018, 97, 809-817. [CrossRef] [PubMed]

275. Pickard, M.R.; Mourtada-Maarabouni, M.; Williams, G.T. Long non-coding RNA GAS5 regulates apoptosis in prostate cancer cell lines. Biochim. Biophys. Acta 2013, 1832, 1613-1623. [CrossRef] [PubMed]

276. Cilek, E.E.; Ozturk, H.; Gur Dedeoglu, B. Construction of miRNA-miRNA networks revealing the complexity of miRNA-mediated mechanisms in trastuzumab treated breast cancer cell lines. PLoS ONE 2017, 12, e0185558. [CrossRef] [PubMed]

277. Xie, M.; Ma, L.; Xu, T.; Pan, Y.; Wang, Q.; Wei, Y.; Shu, Y. Potential Regulatory Roles of MicroRNAs and Long Noncoding RNAs in Anticancer Therapies. Mol. Ther. Nucleic Acids 2018, 13, 233-243. [CrossRef]

278. Aggarwal, V.; Priyanka, K.; Tuli, H.S. Emergence of Circulating MicroRNAs in Breast Cancer as Diagnostic and Therapeutic Efficacy Biomarkers. Mol. Diagn. Ther. 2020, 24, 153-173. [CrossRef] 